\title{
ARTICLES
}

\section{THE WTO'S READING OF THE GATT ARTICLE XX CHAPEAU: A DISGUISED RESTRICTION ON ENVIRONMENTAL MEASURES}

\author{
SANFORD GAINES
}

\section{INTRODUCTION}

The World Trade Organization ("WTO") has a commitment to "an open, non-discriminatory and equitable muliblateral trading system on the one hand," and to "protection of the environment, and the promotion of sustainable development on the other." 1 The dual commitment expresses the conviction of the world's trade ministers that, "there should not be, nor need be, any policy contradiction" 2 between these two policy goals, a belief first officially

- Professor, University of Houston Law Center. B.A.; J.D.; M.A., Harvard University. I want first to thank Monona Banerji, UH Law Center, LL.M., 1999, for her outstanding research assistance. I also benefited from information, insights, and perspectives of WTO Secretariat staff and member country representatives during interviews in Geneva in December 1999. The comments of law faculty of the Alberts-Ludwig University of Freiburg, Germany, researchers of the European University Institute in Florence, Italy, and the law faculty of the University of Oslo, where I presented drafts of this paper in December 1999, April 2000, and May 2000 respectively, helped sharpen my thinking about the issue at stake. Finally, my thanks to the University of Houston Law Foundation for financial support for summer research and travel.

1 Preamble of the (Marrakesh) Ministerial Decision on Trade and Environment, April 15, 1994, GATT/MTN.TNC/MIN(94)/1/Rev.1 [hereinafter Marrakesh Decision]. The Ministerial Decision was published as part of the documentation of the agreements establishing the World Trade Organization ("WTO"). The trade ministers of the WTO "strongly" reaffirmed their commitment to these objectives at their ministerial conference in Doha, Qatar, in November 2001. Sac Ministerial Declaration, WT/MIN(01)/DEC/W/1, para. 6 (Nov. 14, 2001).

2 Marrakesh Decision pmbl. 
enunciated at the United Nations Conference on Environment and Development. ${ }^{3}$ The WTO's persistent but hesitant effort to construct a trade law framework for resolving contradictions between trade liberalization and environmental protection has focused on the interpretation of Article XX of the General Agreement on Tariffs and Trade ("GATT"). The relevant text of Article $X X$ is brief and worth setting forth in full at the start:

Subject to the requirement that such measures are not applied in a manner which would constitute a means of arbitrary or unjustifiable discrimination between countries where the same conditions prevail, or a disguised restriction on international trade, nothing in this Agreement shall be construed to prevent the adoption or enforcement by any Member of measures: ...

(b) necessary for the protection of human, animal, or plant life or health;... [or]

(g) relating to the conservation of exhaustible natural resources if such measures are made effective in conjunction with restrictions on domestic production or consumption; ....4

Article $X X$ thus offers general exceptions from international trade obligations for unilateral trade measures in pursuit of specified purposes, including "the conservation of exhaustible natural

3 Agenda 21, para. 2.19, U.N. Doc. A/CONF.151/26, published with annotations in AGENDA 21: EARTH's ACTION PLAN (Nicholas A. Robinson ed., 1993).

4 Final Act Embodying the Results of the Uruguay Round of Multilateral Trade Negotiations, Apr. 15, 1994, LEGAL INSTRUMENTS-RESULTS OF THE URUGUAY ROUND vol. 1 (1994), 33 I.L.M. 1125 (1994), Annex 1A, General Agreement on Tariffs and Trade, 1994 [hereinafter GATT]. The GATT 1994 supersedes, but incorporates, the original GATT 1947 as that had been amended from time to time. See id. para. 1(a); see also GATT art. II:4 (stating that the GATT 1994 is "legally distinct from" the GATT 1947). 
resources." The chapeau ${ }^{5}$ of Article $\chi \chi$, however, demands adherence to certain bedrock trade norms as a prerequisite to the general exceptions. The Article $X X$ chapeau thus poses a critical question for trade-environment policy: within the economic framework of multilateral trade, under what conditions should national governments have policy space to pursue ecological goals by restricting international trade in certain goods in order to promote the conservation of environmental resources harmed by production of those goods?

In 1989, as part of a program to protect the diminishing populations of sea turtles around the world, the United States enacted a law that barred the import into the United States of wild-caught shrimp harvested with technology that could adversely affect sea turtles unless it came from a country that had adopted a program for turtle protection comparable to the U.S. program. For all practical purposes, the U.S. program simply required shrimp trawlers to install and use "turtle excluder devices" ("TEDs"). Although the U.S. government initially applied this embargo provision only against countries in the wider Caribbean, a federal court in late 1995 ordered the law applied worldwide, as of May 1996.6 Four Asian countries that harvest and export shrimp to the United States, newly subject to the embargo provision, initiated dispute settlement with the United States in the WTO in late 1996, claiming that the embargo violated U.S. obligations to them under the GATT.7 A dispute settlement panel ruled in favor of the Asian claimants in May 1998.8 The United States appealed several legal conclusions in that ruling to the Appellate Body of the WTO. Criti-

5 That is, the "Subject to..." clause. In international law, an unnumbered introductory clause or paragraph covering several subsequent provisions is called a chapeau ("cap" or "hat").

6 This history is recounted in more detail infra Section 3.2.

7 Formal dispute settlement in the WTO was initiated through a joint request for consultations with the United States by India, Malaysia, Pakistan, and Thailand, on October 8, 1996. India and Thailand are consistently among the largest suppliers of shrimp to the United States market. The history' of the dispute is recounted in the Report of the WTO Dispute Settlement Panel, United Stales - Import Prohibition of Certain Shrimp and Slrimp Products, WT/DS5S/R (May 15, 199S) [hereinafter Panel Report]. This report is available through the WTO website list of dispute settlement reports at http://www.wto.org/english/tratop_e/dispu_e /distab_e.htm.

8 Id. 
cal to the appeal was the question whether the implementation of the United States law met the conditions of the Article XX chapeau.

In its 1998 report, United States-Import Prohibition of Certain Shrimp and Shrimp Products ("Shrimp-Turtle"), the Appellate Body of the WTO characterized its task in interpreting the chapeau as, "the delicate one of locating and marking out a line of equilibrium between the right of a Member to invoke an exception under Article $X X$ and the rights of the other Members under varying substantive provisions ... of the GATT 1994."10 The "line of equilibrium," in the Appellate Body's view, should ensure that "neither of the competing rights will cancel out the other and thereby distort and nullify or impair the balance of rights and obligations constructed by the Members themselves in that Agreement."11 Accepting the fundamental premise that a mutually supportive relationship between trade and environment policies requires respect for each goal, this Article closely examines the reasoning in ShrimpTurtle to assess whether the Appellate Body properly located the elusive "line of equilibrium."

Although Shrimp-Turtle held that the U.S. shrimp embargo did not meet the chapeau's conditions, the report has been hailed nonetheless as "a landmark decision"12 that marks "a departure from past [GATT/WTO] decisions in tone and reasoning," 13 and so "signals a positive trend in international trade law for using unilateral trade bans to protect the environment" 14 that "offers hope for

9 Report of the Appellate Body, United States-Import Prohibition of Certain Shrimp and Shrimp Produts, WT/DS58/AB/R (Oct. 12, 1998) [hereinafter AB Report]. This report can also be retrieved through the WTO website list of dispute

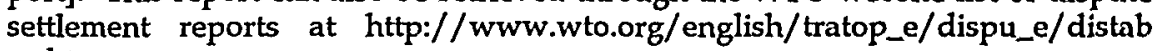
_e.htm.

10 Id. para. 159.

11 Id.

12 Dukgeun Ahn, Environmental Disputes in the GATTMTO: Before and After U.S. Shrimp Case, 20 MiCH. J. INT'L L. 819, 822 (1999) (crediting the AB Report with "resolving some critical and long debated issues").

13 Richard W. Parker, The Use and Abuse of Trade Leverage to Protect the Global Commons: What We Can Learn from the Tuna-Dolphin Conflict, 12 GEO. INT'L ENVTL. L. REV. 1, 5 (1999).

14 Brett Grosko, Note, Just When Is It That a Unilateral Trade Ban Satisfies the GATT?: The WTO Shrimp and Shrimp Products Case, 5 ENVT'L LAW. 817, 840-41 (1999). 
greater environmental protection in the future."15 The United States Government itself generally welcomed the report.16 In a similar vein, the supposedly victorious Asian countries insist that the Appellate Body created too broad an allowance for unilateral trade measures for environmental purposes. ${ }^{17}$ Such reactions lend support to Professor John Jackson's assessment that environmental interests have "lost some battles, but won the war" in the WTO.18

This Article comes to a decidedly more skeptical judgment of Shrimp-Turtle. As I see it, the environmental interests lost important battles there that leave the war far from won. Although Shrimp-Turtle shows a refreshing appreciation of global environmental policy and opens the door to unilateral national environmental measures under Article $X X(\mathrm{~g})$, that open door only leads to a second and more tightly guarded gateway, the Article $X \times$ chapeau. In concluding that the United States applied its law contrary to the conditions established by the chapeau, the Appellate Body unduly privileged trade considerations, showed little understanding of how environmental policy works, and gave little ground for hope that the WTO will tolerate any real-world unilateral use of trade leverage in furtherance of environmental protection objec-

15 Suzanne Pyatt, The WTO Sea Turtle Decision, 26 Ecology L.Q. 815, 831 (1999).

16 This was indicated by the statement of the United States at a meeting of the Council of the WTO on November 6, 1998, stating, inter alia, that "the Appellate Body had also made a number of important and positive findings that helped clarify the critical relationship between WTO rules and measures taken to protect the environment." WTO Dispute Settlement Body, Minules of Mreting - Held in the Centre William Rappard on 6 November 1998, WT/DSB/M/50 (Dec. 14, 1998).

17 This opinion was expressed, occasionally in vehement terms, during a personal interview by the Author with a representative of the government of India to the WTO, in Geneva, Switzerland (Dec. 13, 1999); representatives of Thailand expressed similar views, though less vociferously, in a separate personal interview in Geneva on the same day [hereinafter Interviews]. The government of Malaysia expressed its dissatisfaction more formally in its arguments during its "recourse" proceedings under Article 21.5 of the Dispute Settlement Understanding, arguing that the GATT requires the import prohibition itself to be removed entirely, not simply applied more fairly. See Panel Report, United States - Import Prohibition of Certain Shrimp and Shrimp Products, Recourse to Article 21.5 of the DSU by Malaysia, paras. 3.35-.37, 3.55-.60, WT/DS58/RW (June 15, 2001) [hereinafter Recourse Panel Report].

18 Michael M. Weinstein, Greens and Globalization: Declaring Defaat in the Face of Victory, N.Y. TIMES, Apr. 22, 2001, \$4, at 18. 
tives reaching beyond national boundaries. ${ }^{19}$ The flawed arguments of earlier cases condemning unilateral measures under Article $X X$ have simply been transferred from the interpretation of $X X(\mathrm{~g})$ to the interpretation of the chapeau. The logic of the analysis now has more elegance, but the bottom line remains the same. Shrimp-Turtle joins a long line of decisions in the WTO and the predecessor GATT in which the trade organization has rejected GATT Article $X X$ excepts from GATT disciplines certain types of national environmental measures that may restrict trade. ${ }^{20}$

This Article's pessimistic assessment is confirmed by the 2001 report of the WTO panel in the follow-on proceeding in the ShrimpTurtle matter brought by Malaysia challenging the sufficiency of the United States policy adjustments in response to the Appellate Body's decision. ${ }^{21}$ Although the panel ultimately finds the revised practices of the United States since 1998 to conform to the rulings of the Appellate Body, it does so only after establishing-improperly, in my view - very high thresholds of performance with respect to the Appellate Body's stipulations. ${ }^{22}$ The just released Ap-

19 The recent report of the Appellate Body upholding French restrictions on the importation of products containing asbestos affirms a much narrower range of national environmental protection authority, the right to exclude certain products from the national market when there is plausible evidence that the products themselves present health or environmental risks for the importing nation that it has deemed unacceptable. WTO Report of the Appellate Body, European Communities-Measures Affecting Asbestos and Asbestos-Containing Products, WT/DS135/AB/R (Mar. 12, 2001) [hereinafter Asbestos].

20 I adhere to this conclusion notwithstanding the Asbestos report, cited supra, note 19. The trade measure at issue in that case was a French decree generally banning asbestos fibers or products containing them but allowing certain exemptions for existing products. After reviewing the health effects evidence, the Appellate Body concluded that the French measure was within the exception of Article $X X(b)$ for measures necessary to protect human health or life. Curiously, though, the report contains no discussion whatever of the chapeau of Article $X X$. Moreover, its interpretation of Article XX(b) was not necessary to the judgment, because the Appellate Body determined after thorough analysis of the issue of "like products" that the French measure was not inconsistent with the basic trade obligations of Article III:4. A recognition that Article XX covers a strict regulation of both domestic manufacture and import of a product determined to present a serious risk to health is helpful, to be sure, but it covers a limited range of national provisions already widely recognized as subject to trade controls.

21 Recourse Panel Report, supra note 17.

22 In particular, the panel sets extraordinary conditions on the "requirement" to make serious good faith efforts to negotiate an international agreement as a precondition to any Article $X X$ measure. Id. paras. 5.43-5.88. See the discussion of 
pellate Body review of the Recourse Panel Report takes some of the hard edges off the panel's conclusions and provides clarification of the main Shrimp-Turtle report that limits some of the damage to Article $X X .{ }^{23}$ Even so, the basic conclusion remains that, far from finding a plausible "line of equilibrium," the original Shrimp-Turtle decision and the latest Appellate Body report establish a WTO rule that imposes extraordinary preconditions on member governments before they resort to Article $X \chi$ for environmental measures. The WTO panel and Appellate Body seem more concerned with hewing to the political objections of WTO members to unilateralism than with the judicial task of rigorously searching in the text of the GATT itself for the "line of equilibrium" between unilateralism and multilateralism.

An avalanche of notes and articles about Slirimp-Turtle have reported its conclusions, ${ }^{24}$ but few have even scratched the surface of

the requirement to pursue multilateral approaches in the text infra Section 4.23., at notes 174-211.

23 Report of the Appellate Body, United States-Import Prolibition of Cortain Shrimp and Shrimp Products, Recourse to Article 21.5 of the DSU by Malmysia, WT/DS58/AB/RW (Oct. 22, 2001) [hereinafter AB Recourse Report].

24 In addition to the articles cited in notes 12,13 , and 15 supra, the following have appeared: Padideh Ala'i, Free Trade or Sustainable Decelopment? An Annlysis of the WTO Appellate Body's Shift to a More Balanced Approach to Trade Literalization, 14 AM. U. INI'L L. REv. 1129 (1999); Axel Bree, Article XX GATT - Quo Vadis? The Environmental Exception after the Shrintp-Turtle Apfellate Body Report, 17 DiCk. J. IrT'L L. 99 (1998); Lakshman Guruswamy, The Annihilation of Sea Turlles: World Trade Organization Intransigence and U.S. Equivocation, 30 ENVTL L.REP. 10,261 (2000); Petros C. Mavroidis, Trade and Environment after the Sltrimps-Turtles Litigation, 31 J.WORLD TRADE 73 (2000); Bruce Neuling, The Shrimp-Turlle Case: Implications for Article XX of GATT and the Trade and Environment Debate, 22 LOY. L.A. INT'L \& COMP. L. Rev. 1 (1999); Eric L. Richards \& Martin A. McCrory, The Sea Turlle Dispute: Implications for Sovereignty, the Environment, and International Trade Lmo, $71 \mathrm{U}$. COLO. L. REv. 295 (2000); Joseph R. Berger, Note, Unilateral Trade Mcasures to Conseroe the World's Living Resources: An Environmental Breakthrough for the GATT in the WTO Sea Turtle Case, 24 ColuM. J. ENvTL. L. 355 (1999); Jennifer A Bernazani, Note, The Eagle, the Turtle, the Shrimp and the WTO: Implications for the Future of Environmental Trade Measures, 15 CoNN. J. INT'L L. 207 (2000); Bret Puls, Note, Thre Murky Waters of International Environmental Jurispnudence: A Critizue of Recmt WTO Holdings in the Shrimp/Turtle Controversy, 8 MiNN. J. GLOBAL. TRADE 343 (1999); Benjamin Simmons, Note, In Seardh of Balance: An Analysis of the WTo Shrimp/Turtle Appellate Body Report, 24 ColUM. J. ENvTL. L. 413 (1999); Susan L. Sakmar, Note, Free Trade and Sea Turtles: The Intermational and Domestic Implications of the Shrimp-Turtles Case, 10 CoLO. J. INT'L ENVTL. L. \& Por'y 345 (1999). 
its legal reasoning.25 This Article seeks to provide the missing legal critique by probing deeply into the Appellate Body's analysis of the GATT Article XX chapeau. It concludes that the Appellate Body's reasoning and textual interpretation are deeply flawed, and argues that the better view of the Article $X X$ chapeau is that the United States law and practice did qualify (with some minor exceptions ${ }^{26}$ for the protection of Article XX. By persisting in making a GATT legal condition out of the WTO's political objections to unilateral trade measures to pursue environmental protection initiatives, the Appellate Body missed the chance to breathe life back into Article XX. Shrimp-Turtle's reading of the Article XX chapeau calls into question the WTO's capacity for supple interpretation of the GATT. WTO policy rigidity is already having profound and troublesome consequences for the freshly vigorous global conversation about trade policy.

25 The most trenchant analysis of the relevant issues appears in an article on the panel report: Robert Howse, The Turtles Panel: Another Environmental Disaster in Geneva, 1998 J. WORLD TRADE 73. The Appellate Body pointedly criticizes the Panel Report, but many of Howse's criticisms apply to the Appellate Body analysis as well. Of the articles describing the $A B$ Report cited in notes 12,13,15 and 24 , supra, Mavroidis, supra note 24 , and Guruswamy, supra note 24 , provide the most substantial critical analysis, and touch on some of the issues that will be addressed in this Article. Guruswamy's critique, however, has a general international law focus, emphasizing inappropriate WTO usurpation of national prerogatives (a valid point that $I$ also raise on occasion) rather than flaws in the Appellate Body analysis of Article XX. Mavroidis approves some elements of the analysis with which I take exception, but his very concise article tends to put the key holdings in the context of WTO jurisprudence rather than to analyze them critically. Bree, supra note 24, and Simmons, supra note 24, get into some of the key issues and have some excellent insights. Neuling, supra note 24, offers a few interesting but rather brief comments on the Appellate Body's reasoning. The other articles and notes promise critical analysis but do not get far beyond a summation of the elements of the Appellate Body report.

26 There were indeed discriminatory elements in the application of the U.S. policy that justify the ultimate WTO ruling. See discussion of these elements in the Section 4.2. infra. I consider these discriminatory aspects "minor" in two important senses. First, they are given rather cursory attention in Shrimp-Turtle, because they were of minor importance under the Appellate Body's analytical approach. Second, they are minor in the sense that they represented disparities in application of the policy that were not an integral aspect of the U.S. statute and implementing regulations, but arose out of unique historical "accidents." Thus, they have no precedential significance for future trade-environment cases. Indeed, in the "recourse" proceeding, the panel concluded that some modest adjustments by the United States and the passage of time had cured these defects. Recourse Panel Report, supra note 17, paras. 5.112 - 5.120. 
Two preliminary observations may help put this Article's analysis into its proper context. First, this Article's strong criticism of Shrimp-Turtle springs from general support for, not hostility to, liberalized trade. I agree with the views of many economists and trade advocates that the efficiency and productivity gains that flow from undistorted international exchange can, and for the most part do, contribute to sustainable development, including enhanced protection of the environment.27 I reject the arguments of those WTO critics who assert that open trade is by its very nature environmentally unsound and who find sustainability salvation only in a return to autarkic modes of localized self-sufficiency. ${ }^{23}$ People of

27 I have said as much before. See Sanford Gaines, Rethinking Environmental Protection, International Trade, and Competitizeness, 1997 U. CHI. LEGAL F. 231. For a fine collection of some sophisticated economic and legal papers making these arguments, see 1 FAIR TRADE AND HARMONIZATION Jagdish Bhagwati \& Robert E. Hudec, eds., 1996) [hereinafter Hudec]. The IVTO recently undertook a major review and synthesis of the literature. See Hakan Nordström \& Scott Vaughan, WTO Secretariat Report, Trade and Environment (1999), available at http://www.wto.org.

28 One of the better-known and more thoughtful of these trade critics is Herman Daly. See HeRMAN E. DALY ET AL, FOR THE COMMON GOOD: REDIRECTING THE ECONOMY TOWARD COMMUNITY, THE ENVIRONMENT, AND A SUSTALNABLE FUTURE (2d ed., 1994). The belief that people will be better off if they were to organize themselves in small, self-sufficient communities has deep roots in utopian philosophy, SEe MaRIUS DE GEUS, ECOLOGICAL UTOPIAS: ENVISIONING THE SUSTAINABLE SOCIET' (1999), but is fundamentally anti-historical. The one area of economic activity where aspirations of self-sufficiency still strongly influence trade policy is agriculture. Developed nations pay staggering economic costs to maintain barriers to agricultural trade to protect their farmers from lower-cost imports, and the environmental benefits of such barriers are debatable. Particularly from the viewpoint of developing countries, the prevailing double-standard of free market access for industrial goods and high trade barriers for agricultural products contributes to their impoverishment and to their degraded environmental condition. For example, the following statements were made at a recent meeting of the U.N. Commission on Sustainable Development:

Pakistan pointed out that many developing countries mistrusted the entire concept of sustainable development, which they felt was consistently "viewed through the prism of the environment," with its social and economic aspects and equity concerns largely forgotten.... Trade, finance and investment were "at the heart of sustainable development," the Pakistani representative said, adding that environmental and social standards that restrain market access worked counter to sustainable development.

CSD Reveals Unchanged Positions on Agriculture, Bridges Beturen Trade and Sustainable Deoelopment, Vol. 4, No. 4, May 2000, at 7, roailable at 
this latter view condemn Shrimp-Turtle because it confirms for them the supposed evils of the WTO, free trade's institutional scapegoat. Shrimp-Turtle causes me deep concern for the opposite reason-because it endangers the multilateral trading system and the environmental benefits to be gained from its further development. Its distorted reading of Article $X X$ does more than any hypothesized upsurge of governmental "green protectionism" to jeopardize the hard-won gains of the last half century toward open patterns of international exchange.

The second prefatory comment concerns the "real-world" consequences of Shrimp-Turtle, and whether the critique of it in the present Article misjudges their import. After the Appellate Body's report, the United States made modest adjustments to its guidelines for implementing its policy. ${ }^{29}$ In announcing these changes, the United States specifically rejected arguments that Shrimp-Turtle required a change in the U.S. statute. ${ }^{30}$ Consequently, the embargo of certain shrimp imports from three of the complaining countries continues in place, ${ }^{31}$ although shrimp caught with TED-equipped boats is admitted even from countries that do not have a certified national program. ${ }^{32}$ A Pyrrhic victory for the Asian countries and a

http://www.ictsd.org/English/BRIDGES4-4.pdf. The Philippine delegate agreed. Id.

29 Revised Guidelines for the Implementation of Section 609 of Public Law 101-162 Relating to the Protection of Sea Turtles in Shrimp Trawl Fishing Operations, 64 Fed. Reg. 36,946 July 8, 1999) (revising the Section 609 guidelines) [hereinafter Guidelines]. See also Sean D. Murphy, U.S. Implementation of WTO Turtle/Shrimp Decision, 94 AM. J. INT'L L. 361 (2000) (reproducing remarks of David Balton, Director of the Office of Marine Conservation, U.S. Dep't of State, delivered Dec. 7, 1999).

30 Revised Guidelines for the Implementation of Section 609 of Public Law 101-162 Relating to the Protection of Sea Turtles in Shrimp Trawl Fishing Operations, 64 Fed. Reg. 36,946 (July 8, 1999).

31 See AGENDA 21, supra note 3, listing countries "certified" under the U.S. program.

32 This policy was implemented before the WTO dispute. Revised Notice of Guidelines for Determining Comparability of Foreign Programs for the Protection of Turtles in Shrimp Trawl Fishing Operations, 61 Fed. Reg. 17,342 (Apr. 9, 1996). During the course of the WTO proceedings, the Court of International Trade struck down this policy, but it was reinstated after an appeals court reversal. The history is recounted in the Revised Notice of Guidelines for Determining Comparability of Foreign Programs for the Protection of Sea Turtles in Shrimp Trawl Fishing Operations, 63 Fed. Reg. 46,094 (Aug. 18, 1998) (reinstating the policy admitting TED-caught shrimp from uncertified countries). The U.S. has imported well over $\$ 100$ million per year of shrimp from India in each of the years 1996- 
real victory for the United States, it would seem. Malaysia certainly thought so in asserting (unsuccessfully) its continuing claim that only complete removal of the embargo would meet WTO requirements. ${ }^{33}$

But the WTO dispute involved general matters of law and principle more than simple commercial matters of market access for shrimp. One of the complaining countries, Thailand, has been certified by the U.S. government since 1996 to be in compliance with the terms of the statute in question, so its shipments of shrimp to the United States have not been adversely affected by the U.S. policy. Malaysia, though advised by the United States that its program could probably be certified under the U.S. law, has dogmatically refused to request certification. ${ }^{34}$ Thailand, Malaysia, and their Asian neighbors seem to have been motivated to bring the dispute by broader policy concerns about U.S. environmental unilateralism (which could apply to other products important to them, such as timber) and by a keen desire they share with most developing countries to establish clear GATT restraints on trade restrictions for environmental purposes. Government representatives of Thailand and India have asserted that, from their point of view, the United States really "won" the Shrimp-Turtle dispute because the Appellate Body marked out such a broad reading of Article $X X(\mathrm{~g}){ }^{35}$ In short, as with so many matters in the law, the practical result for the parties to the case is, for many purposes, secondary to its significance as legal discourse and potential precedent. The reasoning behind the Appellate Body's legal conclusions merits close scrutiny because it will endure as an authoritative interpretation of Article $X X$ for all WTO members and as a source of arguments for disputants and adjudicators in future trade-environment cases.

1999, and smaller quantities from Malaysia and Pakistan. The fourth WTO complainant, Thailand, has shrimp exports to the U.S. in excess of $\$ 1$ billion per year since 1998. Much of the Thai shrimp is farmed shrimp not covered by the Section 609 embargo, but the trade data makes no distinction. Data from the U.S. Dep't of Commerce, National Marine Fisheries Service, mailable at http://www.st.nmfs.gov/ows-trade/trade_cntry_prdct.sh?qtype=IMP\&:qyearl= 1996\&qyear2=2001\&qimproducts=SHRIMP\&qcountry $=\% 25$.

33 Recourse Panel Report, supra note 17, para.3.3.

34 Id. para. 5.115.

35 Interviews, supra note 17. 
This is already apparent in the analysis of Malaysia's follow-on claim about U.S. compliance with the Appellate Body's ruling. ${ }^{36}$

Article $X X$ has long stood at the center of the tradeenvironment policy debate. Section 2 of the Article will frame the legal and policy context in which the Shrimp-Turtle analysis of Article $X X$ now becomes a factor. It will examine how interpretations of Article $X X$ shape many issues in the trade-environment debate, so that the ramifications of Shrimp-Turtle extend far beyond the immediate issue of sea turtle protection and shrimp trade restrictions. Section 3 then gives some of the factual background to the Shrimp-Turtle dispute. From an environmental policy point of view, Shrimp-Turtle's interpretation of Article XX bears particularly close scrutiny because all species of sea turtles are endangered or vulnerable to extinction. ${ }^{37}$ Nearly thirty years ago, the international community took steps to control the threat of species extinction from direct international trade in animals or parts of animals.38 Ecologists and environmental policy makers recognize, however, that the greater threat to the survival of many species is human modification of or interference in their habitat. ${ }^{39}$ Thus, a scientifically sound policy for the protection of endangered species may in some circumstances require control of indirect trade effects as well, that is to say, trade in goods produced or acquired in ways that jeopardize species. This is arguably the situation with sea turtles and the threat to their survival from commercial shrimp trawling. Section 3 also describes the tortuous procedural history of the

36 See generally Recourse Panel Report, supra note 17.

37 See infra notes 69-74 and accompanying text.

38 Convention on International Trade in Endangered Species of Wild Fauna and Flora (CITES), opened for signature Mar. 3, 1973, 27 U.S.T. 1087, 993 U.N.T.S. 243 (1973) [hereinafter CITES].

39 E.g., Agenda 21, para. 15.2, in RoBINSON, supra note 3 ("The current decline in biodiversity is largely the result of human activity and represents a serious threat to human development."). Economists concur. See, e.g., RAYMOND F. MIKESELL, ECONOMIC DEVELOPMENT AND THE ENVIRONMENT: A COMPARISON OF Sustainable DeVelopment WTTH CONVENTIONAL DEVElopMENT ECONOMICS 33-34 (1992) ("Sustainable development ... broadens conventional development objectives by including preservation of the natural resource base to enable future generations to carry on at least an equivalent level of current economic activity."). A recent scientific study comes to the conclusion that land use patterns and global climate change will be the two leading causes of the extinction of plants by the end of this century. Osvaldo E. Sala et al., Global Biodiversity Scenarios for the Year 2100, 287 SCIENCE 1770 (2000). 
United States shrimp embargo policy that gave rise to the dispute in the WTO. In all likelihood, the many twists and turns of U.S. policy distorted the perspective of the Appellate Body in ShrimpTurtle.

Section 4, the central part of the Article, analyzes the Appellate Body's interpretation of the Article $X X$ chapeau, focusing on its extended discussion of the phrase "arbitrary or unjustifiable discrimination." The analysis shows that Shrimp-Turtle has fundamental flaws in its textual analysis. It also identifies fundamental misconceptions in the WTO about the nature of environmental law and policy in both its national implementation and in the way it operates to achieve broader goals of cooperative solutions to international environmental problems. There were, to be sure, some objectionable details in the way the United States applied its shrimp embargo policy to the Asian complainants, but these receive scant attention from the Appellate Body. The weightier parts of the Shrimp-Turtle analysis create enormous obstacles to national trade-based environmental measures that effectively negate Article $X X^{\prime}$ s reservation to individual countries of substantial policy autonomy in conserving natural resources.

The WTO's flawed Article XX jurisprudence contributes to the public's lack of confidence in the ability of the multilateral trading system to accommodate even the most basic and universally accepted imperatives of environmental protection. Left unchanged, the Shrimp-Turtle approach to the chapeau jeopardizes the larger objectives and benefits of the multilateral trading system, including the environmental benefits that can be gained from reducing subsidies to such activities as fishing and agriculture. The WTO needs to find an interpretation of Article $X X$ that will remove the policy contradictions that now exists between environmental protection and international trade rules, policy contradictions contrary to the spirit of the Marrakesh Ministerial Decision. Section 5 will propose ways to re-interpret the Article $X \chi$ chapeau so as to restore Article $X X$ as an appropriate balancing device in the overall trade policy structure. A fresh look at Article $X X$ can open new paths to the resolution of conflicts over trade policy and environment policy interactions. 


\section{ARTICLE $X X$ AND THE TRADE-ENVIRONMENT DEBATE}

One cannot appreciate the policy peril of the WTO's current predicament over Article $X X$ without recalling the decade of tradeenvironment debate preceding Shrimp-Turtle.40 A 1991 dispute settlement panel report ${ }^{41}$ thrust trade law abruptly into the realm of environmental protection policy, and put environmental issues squarely on the agenda of international trade policy development. ${ }^{42}$ The mutual shock produced cries of alarm from environmentalists and trade mavens alike. Ardent environmentalists portrayed the world trade system as "GATTzilla," a monster at the service of unbridled multinational corporations stomping on national environmental laws and bent on ever-expanding production and consumption that would destroy the environment. ${ }^{43}$ Trade advocates conjured their own specter that countries would adopt multiple trade restrictions in the name of the environment and that such "green" protectionism would put the liberalized international trade regime on a "slippery slope" toward the "chaotic trade conditions ... that plagued the 1930s." 44

40 The most complete account of this familiar story remains DANIEL C. ESTY, GREENING THE GATT: TRADE, ENVIRONMENT, AND THE FUTURE (1994) [hereinafter ESTY]. For a shorter analytical review that brings the story closer to the present, see Thomas J. Schoenbaum, International Trade and Protection of the Environment: The Continuing Search for Reconciliation, 91 AM. J. INT'L L. 268 (1997). An excellent summation of the issues keyed to the agenda of the WTO Committee on Trade and Environment was prepared by the IUCN Environmental Law Centre. KENNETH P. EWING \& RICHARD G. TARASOFSKY, INT'L COUNCIL OF ENVTL. LAW, THE "TRADE \& ENVIRONMENT" AGENDA: SURVEY OF MAJOR ISSUES AND PROPOSALS-FROM MARRAKESH TO SINGAPORE (1997).

41 United States-Restrictions on Imports of Tuna, GATT Doc. DS21/R, reprinted in 30 I.L.M. 1594 (1991) [hereinafter Tuna-Dolphin I].

42 To be sure, the trade-environment connection had been appreciated by knowledgeable people for at least twenty years before Tuna-Dolphin. At the time of the Stockholm Conference on the Human Environment in 1972, the GATT had established a working group on environmental measures and international trade, though it was completely inactive until 1991. Academic experts had also examined the issues. See, e.g., SEYMOUR J. RUBIN \& THOMAS R. GRAHAM, EDS., ENVIRONMENT AND TRADE: THE RELATION OF INTERNATIONAL TRADE AND ENVIRONMENTAL POLICY (1982).

43 This reaction and a reproduction of the GATTzilla advertisement appear in ESTY, supra note 40 , at $34-36$.

44 These words of infelicitous fear-mongering came from the GATT Secretariat. To give the full context, the Secretariat commented, "[i]f the door were opened to use trade policies unilaterally to offset the competitiveness effects of different environmental standards, or to attempt to force other countries to adopt 
More dispassionate analysts 45 and more optimistic officials hoped that the trade and environment cultures, which had until then operated in separate spheres, could find in practice the common ground that existed between them in theory. The GATT activated a Group on Environmental Measures and International Trade ("EMTT"), reconstituted in 1995 as the Committee on Trade and Environment ("CTE") of the WTO.46 The Organization for Economic Cooperation and Development studied the issues through meetings of an ad hoc group called the Joint Session of Trade and Environment Experts. ${ }^{47}$ Academic conferences on trade

domestically-favored practices and policies, the trading system would start down a very slippery slope." GATT Secretariat, TRADE AND THE ENVIRONMENT 6 (1992). In phraseology highlighted in the press release accompanying the report, the Secretariat further declared, "[t]o allow each contracting party unilaterally to impose special duties against whatever it objects to among the domestic policies of other contracting parties would risk an eventual descent into chaotic trade conditions similar to those that plagued the 1930s." Id. at 20.

45 E.g., ESTY, supra note 40; Jagdish Bhagwati, Trade and the Environment: The False Conflict?, in TRADE AND THE ENVIRONMENT: LAW, ECONOMIC, AND POLICY (Durwood Zaelke, Paul Orbuch, \& Robert F. Housman, eds., 1993); Jeffrey L. Dunoff, Reconciling International Trade with Preservation of the Global Commons: Cm We Prosper and Protect?, 49 WASH. \& LEE L. Rev. 1407 (1992); John H. Jackson, World Trade Rules and Environmental Policies: Congruence or Conflict?, 49 WASH. \& LEE L.REv. 1227 (1992); Thomas J. Schoenbaum, Free Intemational Trade and Prolection of the Environment: Irreconcilable Conflict?, 86 AM. J.INT'L. L. 700 (1992); Schoenbaum, supra note 40; Edith Brown Weiss, Environment and Trade as Partners in Sustainable Deoelopment: A Commentary, 86 AM. J. INT'L L. 728 (1992).

46 The GATT group was activated at the behest of the countries of the European Free Trade Area, in part as a way to secure effective GATT preparation for the U.N. Conference on Environment and Development. GATT Secretariat, A FACTUAL NOTE OF TRADE AND ENVIRONMENT IN THE GATT/WTO 6-7, GATT Doc. L/6896 (Sept. 18, 1991). The continuing strong public pressure to find satisfying resolutions to the trade-environment "conflict" led the world's trade ministers, on the occasion of their meeting in Marrakesh to finalize the Uruguay Round to direct the new WTO to establish a Committee on Trade and Environment. Decision of April 14, 1994, Marrakesh Decision, supra note 1. Although that committee does not have permanent status, it seems destined to continue indefinitely.

47 See OECD, "Trade and Environment, June 1993," OCDE/GD(93)99, crailable at http://www.oecd.org/env/docs/gd9399.pdf (reporting on meeting of the Joint Session of Trade and Environment Experts to the Council of Ministers). 
and environment proliferated. 48 Research and advocacy organizations quickly compiled or wrote trade-environment studies. ${ }^{49}$

Although ten years of regular intergovernmental meetings in various fora since Tuna-Dolphin I have deepened understanding of the issues, they have yielded scant progress in official negotiations toward new trade-environment policy approaches.50 Isolated examples of deeper reconciliation and concrete policy adjustments toward mutual support between liberal trade and environmental protection ${ }^{51}$ only throw into sharper relief persistent fundamental differences of outlook and distrust of motives between the trade and environmental communities.

48 Papers from a conference at Washington and Lee University in 1992 are cited in note 45 , supra. Other examples include a conference at Georgetown focusing on trade and environment in NAFTA, 5 GEO. INT'L ENVTL. L. REV. 1 (1993), and one held at Cornell on "Greening the GATT," 27 CORNELL INT'L L. J. 1 (1994).

49 Among the early efforts are: World Bank, International Trade and the Environment (Patrick Low, ed., 1992); C. Ford Runge, Freer Trade, Protected Environment: Balancing Trade Liberalization and Environmental Interests (1994) (Council on Foreign Relations); Durwood Zaelke et al., eds., supra note 45 (Center for International Environmental Law); and ESTY, supra note 40.

50 A perusal of the regular bulletins from the WTO on the discussions in the Committee on Trade and Environment shows how little consensus has emerged. These bulletins are available on the WTO website at http://www.wto.org /english/tratop_e/envir_e/bull_e.htm. The reports on certain issues in 1999 and 2000 repeat many of the same points raised in the work of the GATT working group in the early 1990s. Cf. Report by Ambassador H. Ukawa (Japan), Chairman of the Group on Environmental Measures and International Trade, to the 49th Session of the Contracting Parties, GATT Doc. L/7402, Feb. 2, 1994.

51 One institutional innovation as the creation of the Commission for Environmental Cooperation as an adjunct to the North American Free Trade Agreement. Even in this commission, however, lack of interest in and sometimes outright opposition to policy reform on the part of the national trade agencies has kept the commission from going much beyond data collection and analytical studies. On the commission generally, see PIERRE MARC JOHNSON \& ANDRÉ BEAULIEU, THE ENVIRONMENT AND NAFTA (1996). The academic nature of much of the commission's work is especially evident in its approach to the issue, squarely within its mandate, of assessing the effects of liberalized trade on the environment. The stated goal of this work is simply "to better understand the linkages between environment and trade in the NAFTA context." This will be done by "actively disseminating the Final Analytic Framework for assessing the environmental impacts of trade liberalization measures under NAFTA, and convening leading trade and environment policy centers to test and refine the methodology for assessing the environmental impacts of trade." From the project description at http://www.cec.org/programs_projects/trade_environ_econ/nafta/proj112.cfm ?varlan=english. 
From the very beginning of activity in the GATT EMIT group, the interpretation of Article XX has been central to the discussion. In the international reaction to Tuna-Dolphin I the United States stood virtually alone in its insistence that Article $X X$ allows scope for unilateral trade measures to protect the environment.52 TunnDolphin I also raised doubts about whether Article $X \chi$ would cover multilateral agreements that impose trade restrictions as core elements of their environmental protection strategies.53 Disavowing any intention to let trade rules interfere with multilateral cooperation on environmental protection, many trade officials saw a political need to reassure the world that the GATT would not become a vehicle for individual governments to threaten such globally important environmental commitments. Toward that end, governments proposed either amendments to Article $X X$ or agreed "understandings" of Article $X X$ to give more definitive protection to multilaterally agreed trade measures than to unilateral measures. Other governments, however, insisted that Article $X X$ provides the appropriate rules for judging such multilaterally-agreed trade measures and should not be amended. The EMIT group was unable to resolve these differences. In 1994, the world's trade ministers charged the new WTO Committee on Trade and Environment to consider further "the relationship between the rules of the international trading system and trade measures for the protection of the environment, in particular measures pursuant to multilateral environmental agreements," and to propose appropriate changes to trade rules. ${ }^{54}$ Seven years later, disagreement persists in the WTO about whether, much less how, to amend or interpret Article $X X$ to protect multilateral environmentally-based trade measures. ${ }^{55}$

52 Robert E. Hudec, GATT Legal Restraints on the Use of Trade Measures Against Foreign Environmental Practices, in Hudec, supra note 27, at 95, 117.

53 Discussion focused on three important and well-known agreements: Convention on International Trade in Endangered Species of Wild Fauna and Flora (CITES), supra note 38; Montreal Protocol on Substances that Deplete the Ozone Layer, Sept. 16, 1987, 26 I.L.M. 1541; Conference of Plenipotentiaries, Basel Convention on the Control of Transboundary Movement of Hazardous Wastes and Their Disposal, Mar. 22, 1989, UN Doc. EP/IG.80/3, reprinted in 28 ILM 649 (1939).

54 This is the way the Marrakesh ministerial decision on trade and environment framed the issue for the CTE. Marrakesh Decision, supra note 1.

55 See, e.g., the discussion of trade and multilateral environmental agreements at a July 5-6, 2000, meeting of the Committee on Trade and Environment. WTO Trade and Environment News Bulletins, TE/033, July 10, 2000, at 
The inability of governments to agree on any adjustments to Article $X X$ interpretation reflects the larger controversies over the trade-environment relationship. Because the issues are complex and divisive on the domestic as well as the international level, most politicians have declined to exercise strong leadership to bridge the differences.56 The violent street demonstrations on the occasion of the 1999 Seattle meeting of world trade ministers, repeated since in many other cities, symbolize the deep mutual suspicion and the clash of values that characterize the debate over how to integrate environmental policy objectives into trade policy. The demonstrations signal that the pressure for reform of trade policy has become an inescapable reality for political leaders. President Clinton, always astute about public opinion, endorsed the environmentalists' basic message in remarks in Seattle at the time of the WTO ministerial. ${ }^{57}$ The failure of the trade ministers thereafter to reach agreement on a "millennial round" of trade negotiations encompassing environmental issues confirmed for many in civil society that trade experts fail to comprehend the urgent need to make room for environmental objectives within the realm of trade policy.

Trade-environment conflicts continue to arise and need to be resolved. Given the barrenness of official negotiations toward new policy approaches, governments in serious cases have had no option but to resort to the dispute settlement process of the GATT/WTO. Each such dispute has challenged the trade policy consistency of a national measure, taken by one country alone, restricting trade in some way for environmental protection purposes. The resulting jurisprudence has focused almost exclusively on the

http://www.wto.org/english/tratop_e/envir_e/te033_e.htm. See also IUCN Survey, supra note 40 (summarizing the CTE deliberations through 1997 ).

56 For example, the United States has been managing its trade policy for the past six years without any delegation of authority from Congress for the Executive Branch to negotiate broad-scale trade agreements that Congress would accept or reject without amendment. This policy deadlock stems in part from sharp partisan differences about how to address the trade-environment relationship. For the latest dispatch from this battlefront (as of this writing), see David E. Rosenbaum, Gephardt Says He Will Resist Bush on Trade, N.Y. TiMEs, Oct. 5, 2001 at B8 (reporting Gephardt's view that a trade bill favored by President Bush is "loose, vague, unclear, imprecise, not sufficient" on the questions of labor rights and environment).

57 David E. Sanger, The Overview: President Chides World Trade Body in Stormy Seattle, N.Y. TIMES, Dec. 2, 1999, at A1. 
criteria for the allowance of such national measures under GATT Article $X X$. By default rather than by choice, then, dispute settlement panelists and the WTO Appellate Body have shaped tradeenvironment policy through interpretation of Article XX.

The 1991 Tuna-Dolphin I panel report laid down a very restrictive interpretation of Article $X X .^{58}$ The panel focused its attention on whether the disputed measure came within the scope of Article $X X(b)$ or $(g)$. It held that those paragraphs allow measures only to protect the environment within the jurisdiction of the government adopting the trade measure, and do not cover a measure to prevent environmental harm or protect a resource occurring entirely outside its jurisdiction. ${ }^{59}$ In Tuna-Dolphin II, a different panel found no basis in the GATT or its negotiating history for such a jurisdictional limitation on Article XX. Even so, the panel concluded that the U.S. tuna embargo did not qualify under $X X(\mathrm{~g})$ because it did not protect the dolphin resource directly but operated by putting trade pressure on other governments to change their policies with respect to dolphin protection.60 Thus, in the panel's view, the measure could not be considered to be "primarily aimed at" dolphin conservation within the meaning of $X X(\mathrm{~g}) .{ }^{61}$

58 Tuna-Dolphin I was never officially adopted by the GATT Council; Mexico, then deep into negotiations with the United States on the North American Free Trade Agreement, decided not to pursue its GATT remedies further. TumaDolphin I, supra note 41 . Nevertheless, most governments take the panel's report as an authoritative statement of GATT law. In any event, as made clear in the discussions in the GATT Group on Environmental Measures and International Trade, Tuna-Dolphin I expresses widely-shared understandings of the GATT.

59 Id. paras. 5.25-5.26, 5.31-5.32.

60 United States - Restrictions on Imports of Tuna (Tuna II), GATT Doc. DS29/R (16 June 1994) [hereinafter Tuna-Dolphin II], paras. 5.23-5.27.

61 At that time, the panel was relying on an earlier dispute settlement ruling in Canada Measures Affecting Exports of Unprocessed Herring and Salmon, Mar. 22, 1988, GATT B.I.S.D. (35th Supp.) at 98, 114 (19S9), in which the "relating to" language in Article $X X(\mathrm{~g})$ was construed to mean that the measure must be "primarily aimed at" the conservation of the resource. The IVTO Appellate Body has since softened that interpretation. Without abandoning the "primarily aimed at" formula, it has construed that as requiring only a "substantial relationship" between means and ends. See AB Report, supra note 9, paras. 136, 141-42; Reformilated Gasoline, infra note 64, at 16-17 (observing that "primarily aimed at" is not itself treaty language and was not designed as a simple litmus test for inclusion or exclusion from Article $X X(\mathrm{~g})$ ). For a criticism of GATT jurisprudence on the "relating to" test, see Schoenbaum, supra note 40, at 278-79. 
Another trade-environment case became the very first dispute under the revamped WTO Dispute Settlement Understanding.62 This case involved a U.S. regulation on gasoline quality that applied differently to imported gasoline from the way it applied to gasoline refined in the United States. After an adverse panel report, the United States used the new WTO procedures to seek an improved legal analysis of Article XX from the Appellate Body, a permanent group of legal experts with authority to review and revise legal interpretations in dispute settlement panel reports. ${ }^{63}$

In its report on reformulated gasoline, ${ }^{64}$ the Appellate Body propounded a more sophisticated and flexible analysis of Article $X X$. It isolated the issue of the scope of measures defined by Article $X X(\mathrm{~g})$ from the broader question about the application of Article $X X$ as a whole and then relaxed the interpretation of Article $X X(\mathrm{~g})$ in two respects. First, the Appellate Body declared that the question of whether the measure was within the scope of paragraph (g) should be answered by considering the overall objective of the program in which the trade measure appeared, not just the disputed trade measure viewed in isolation. 65 Second, it took a broad view of the term "exhaustible natural resource," finding that a resource like "clean air" fell within its ambit.66 On these two grounds, the Appellate Body held that the United States program for gasoline quality regulation qualified "provisionally" under paragraph $(\mathrm{g})$.

The Appellate Body then shifted its attention, for the first time in any such proceeding, to the conditions placed on the use of a measure in the chapeau to Article $X X$, which require, in part, that measures not be applied in a way that leads to "arbitrary or unjustifiable discrimination" between countries. The Appellate Body concluded that the way the United States applied the reformulated gasoline provisions of the Clean Air Act had discriminated against

62 Uruguay Round, Understanding on Rules and Procedures Governing the Settlement of Disputes, Final Act, supra note 4, annex 2 (defining the rules and procedures in the settlement of disputes between Members).

63 Id. art. 17.

64 Appellate Body Report on United States Standards for Reformulated and Conventional Gasoline, 35 I.L.M. 603, WT/DS2/AB/R (1996) [hereinafter Reformulated Gasoline].

65 Id. at 1056-57 (construing the term "measures").

66 Id. at 1057-59. However, the conclusions on this point are rather oblique. 
gasoline refined abroad and imported into the United States as compared to domestically refined gasoline in ways that could not be justified by the environmental objectives of the law, and therefore did not meet the Article $X X$ requirement that the measure not result in "unjustifiable discrimination."67 Given the facts in Reformulated Gasoline, the Appellate Body was able to make a straightforward application of the chapeau conditions in reaching this conclusion. The United States regulations were facially discriminatory between domestic and foreign refiners in applying different calculations of the 1990 baselines against which the quality of the reformulated gasoline was measured. The discriminatory differences stemmed from enforcement considerations about verification of baseline data, not because of air quality concerns about the quality of imported gasoline as compared with domestic gasoline. ${ }^{\epsilon s}$ Under these circumstances, the Appellate Body did not need to develop an elaborate interpretation of "arbitrary or unjustifiable discrimination" to find that the discrimination in the United States gasoline rules was "unjustifiable."

The Reformulated Gasoline report, published about a year before the Shrimp-Turtle dispute arose, put Article $X X$ in a new light. Future Article XX cases, it now appeared, would not turn on whether the trade measure addressed an environmental issue covered by Article $X X(b)$ or $(g)$ ("Tuna-Dolphin I"), or even whether the effect of the measure on environmental quality was direct or indirect ("Tuna-Dolphin II"). The major issue would become whether the challenged government had applied a measure within the scope of (b) or (g) in a way that resulted in "arbitrary or unjustifiable dis-

67 Id. at 1073.

65 The Appellate Body was also aware that an initiative by the Environmental Protection Agency ("EPA") to amend its rules to alleviate the discriminatory effect and thereby resolve the trade dispute was blocked by a congressional rider on EPA's budget. Although the Appellate Body did not rely on this history as a basis for its holding, the congressional intervention contradicts the argument that environmental quality was the rationale for maintaining the discriminatory rule and suggests that economic protectionism of U.S. refiners was the primary interest. (The rider was initiated by a member of Congress representing the district that is home to Sunoco, which competes in the East Coast market with Citgo, the U.S. sales subsidiary of the Venezuelan state oil company.) On this basis, the reformulated gasoline rule could also have been disqualified under Article $X X$ as a "disguised restriction on trade." Id. at 30 (quoting Panel Report, supra note 7, para. 5.138). 
crimination" contrary to the conditions in the chapeau to Article $X X$.

\section{THE FACTUAL BACKGROUND TO THE SHRIMP-TURTLE DiSPUTE}

This Section summarizes the key facts behind the Appellate Body's legal conclusions on the scientific connection between shrimp fishing and sea turtle mortality and on the United States' regulatory efforts to control shrimp trawling to protect sea turtles. It reviews the ecology of sea turtles and the effects of shrimp trawling on turtle populations. ${ }^{69}$ Next, this Section turns to the more complex story of the United States statutory and administrative response to the relationship between shrimp and sea turtles in the marine environment. The Appellate Body's skeptical assessment of how the United States administered its law permeates the analytical core of Shrimp-Turtle.

\subsection{The Ecological Issue: Protecting Endangered Sea Turtles from Human Activity}

Found in most warm water ocean environments of the world, sea turtles are long-lived air-breathing marine creatures. Sea turtles hatch on beaches in specific locations to which reproducing females in each population periodically return to lay their eggs. After hatching, they head directly for the ocean, where they spend their entire lives. Although their juvenile and adult life-cycles are not fully understood, sea turtles are known to travel enormous distances. Some turtles hatched in the Gulf of Mexico voyage to the coast of Africa; turtles from southeast Asian populations venture as far as the western coast of South America. Nevertheless, because the females return to their birthplace to lay their eggs, each population remains distinct.

Having survived for more than 100 million years the natural vicissitudes of continental movements, ice ages, asteroid impacts,

69 More details are readily available elsewhere. A good brief survey of the state of scientific knowledge, complete with references, can be found in Center for International Environmental Law et al., Amicus Brief to the Appellate Body on the United States' Import Prohibition of Certain Shrimp and Shrimp Products, 3 August, 1998, at 8-10. The WTO dispute settlement panel benefited from the appointment of scientific experts who reviewed most of what is known, and not known, about the life cycle of sea turtles. See Transcript of the Meeting with Experts held on January 21 and 22, 1998, in Panel Report, supra note 7, annex 4. 
and other forces that have shaped and reshaped the world's life forms, sea turtles are among the most ancient of the world's animals. Yet today, because of human activity, all seven species of sea turtles are internationally recognized as endangered or vulnerable to extinction.70 Particularly susceptible to humans when concentrated on beaches during nesting and hatching, turtles suffered in the past from raiding of nests for eggs, alteration of nesting beaches, and capture of adults for meat and shells. Nations around the world have made substantial efforts in recent decades to reduce such direct taking and disturbance.

As commercial fishing has intensified in all oceans, the incidental capture or drowning of sea turtles in fishing gear has become a leading factor in the continuing decline of sea turtle populations.71 Although sea turtles can stay under water for long periods, they need to come to the surface occasionally for air. They drown when trapped or entangled in fishing gear that is kept submerged for hours at a time. This incidental take has severe effects on populations because it kills adolescent and young adult turtles which, having survived natural predation during their juvenile phase, represent the current and future reproductive potential of sea turtles.

70 Michael Guinea, one of the five experts appointed to advise the WTO dispute settlement panel in Shrimp-Turtle, stated that "[h]uman activities have been nominated as the causative agents in every decline." Panel Report, supra note 7, para. 5.61. The Panel itself states as a matter of "fact" that "[s]ea turtles have been adversely affected by human activity." Id. para. 2.3. All seven species of sea turtles are listed in Appendix I to the Convention on International Trade in Endangered Species (CITES) as being threatened with extinction. CITES, supra note 38. The 1996 "Red Data Book" of the International Union for the Conservation of Nature (IUCN, now known as the World Conservation Union) lists six species as endangered, one of them, the hawksbill, as "critically endangered," and one, the Australian flatback (which is found only in Australian waters) as "vulnerable." Panel Report, supra note 7, para. 23.

71 All the experts consulted by the WTO Panel agree that incidental mortality from commercial fishing is a significant factor contributing to the turtle population declines. See, e.g., Panel Report, supra note 7, para. 5.100 ("Fishing operations cause mortality-albeit incidental-which impacts large turtles, including those that are breeders and close to breeding.") (statement of Dr. John Frazier). They disagree among themselves only about the relative importance of direct and indirect activities in particular countries, or whether scientists even know enough to rank the importance of the various effects for specific populations. Sce generally Panel Report, supra note 7, Part V-Panel's Consultation with Scientific Experts. 
Many experts identify incidental mortality from shrimp trawling in particular as one of the most significant threats to sea turtle populations.72 Shrimp trawling takes place in tropical or subtropical coastal waters frequented by sea turtles, and is locally intensive. The trawls are routinely submerged long enough that most turtles caught in the nets will drown. To reduce turtle mortality from shrimp trawling, experts developed the turtle excluder device, or TED. The TED is a simple adaptation to trawling gear, costing no more than a few hundred dollars per net fully constructed, much less if made by fishermen themselves with local materials. ${ }^{73}$ The TED consists of a "trap door" at the top of the net through which sea turtles can escape. According to United States studies, the TED reduces incidental sea turtle mortality by about ninety-seven percent with little loss of shrimp and minimal effect on the efficiency of shrimping operations. ${ }^{74}$ Disagreement about what governments should do and should be allowed to do in response to these ecological and technological facts gave rise to the WTO dispute.

\subsubsection{The Saga of Section 609}

The United States took three steps in response to the ShrimpTurtle relationship. First, it imposed stringent regulations on the

72 E.g., "By far the most serious threat to sea turtle stocks living in coastal communities are trawl fisheries." Statement of Dr. Scott Eckert, Panel Report, sttpra note 7, para. 5.119. A slightly more cautious view comes from Dr. John Frazier: "Because of its nature, bottom trawling is known to cause major impacts on non-target species because it is an unselective method of fishing. Shrimp trawls are notoriously unselective, and on a world level it has been estimated that they are responsible for more than a third of all by catch." Id. at 5.122 (internal citations omitted). All the WTO Panel experts agreed that shrimp trawling was the major threat to sea turtles in the United States. Id. at 5.113(b) (Mr. H.-C. Liew); Annex IV, para. 18 (Mr. M. Guinea). The CIEL et al. Amicus Brief, supra note 69, at 10-11, notes that international expert bodies, such as the IUCN (World Conservation Union) Marine Turtle Specialist Group, have identified trawling regulation as a "priority."

73 Panel Report, supra note 7, para. 3.79. The report gives the U.S. figures, which were questioned but not seriously discredited by the complaining countries. Id. Ironically, some of the contradictory data was provided by Thailand, even though Thailand had, by the time of the panel hearing, implemented a comprehensive TED program along the U.S. model. Id. paras. 3.80-3.93.

74 Id. para. 3.80. The United States estimates that one to three percent of shrimp are lost when TED-equipped nets are used. Again, there was dispute among the WTO experts about the specific figures in the U.S. studies, but the general effectiveness of TEDs was not fundamentally discredited. 
United States shrimp fleet, eventually requiring essentially all boats to use TEDs at all times. ${ }^{75}$ The second and third steps grew out of the TED requirement. The regulated community of American shrimp trawlers protested vehemently against the TED regulation, 76 motivated in part by concern that the new requirements would weaken their competitive position vis-à-vis shrimp imports from countries not using TEDs. At the same time, sea turtle experts and environmentalists warned that the United States measures, by themselves, would be insufficient to arrest sea turtle population decline around the world. Effective conservation, they argued, could only be achieved if shrimp trawlers in other countries also took steps to protect sea turtles from fishing operations. 7 The commercial and environmental interests converged to support Congress enactment in 1989 of a provision known as Section 609.78 Section 609 contains the other two steps in United States ShrimpTurtle policy, a carrot and a stick that together extend turtle protection beyond the limited confines of United States waters and exclusive economic zone.

The carrot, Section 609(a), calls upon the departments of state and commerce to initiate negotiation of agreements with other countries "for the protection and conservation of sea turtles," specifically including all governments with jurisdiction over commercial fishing operations that "may affect adversely such species of sea turtles." The stick comes in Section 609(b), which prohibits,

T5 With the TED technology available, the U.S. Department of Commerce, under the authority of the U.S. Endangered Species Act, 16 U.S.C. 1531, 1531-1544, promulgated regulations in 1987 requiring larger shrimp trawlers to use the TEDs and smaller trawlers to use TEDs or reduce the time of each tow of the trawl net. Sea Turtle Conservation; Shrimp Trawling Requirements, 52 Fed. Reg. 24,244 (June 29, 1987). The regulations exempt certain types of trawls that do not threaten sea turtles, as well as trawls retrieved manually because such trawls must be retrieved frequently to avoid drowning sea turtles. These regulations became effective on May 1,1990. They were subsequently strengthened to eliminate the shorter tow-time option for smaller boats and to include operations in bays and estuaries as well as in open water. 58 Fed. Reg. 9,016 (Feb. 18, 1993).

76 Dropping the Net on Gulf Shrimpers, NEWSWEEK, Aug. 7, 1989, at 28.

7 Guruswamy, supra note 244, at 262 (noting that the Congress asked for a scientific study of the threat to sea turtles from the National Research Council, which was almost complete at the time of enactment of the embargo provision at issue in Shrimp-Turtle).

78 Section 609 of Pub.L.No. 101-102, codified as a Note to 16 U.S.C. 1537, a section of the Endangered Species Act addressing international cooperation. 
after May 1, 1991, the import of wild-caught shrimp "which have been harvested with commercial fishing technology which may affect adversely such species of sea turtles." Exporting nations are exempted from this prohibition if "certified" by the president based on "documentary evidence of the adopiion of a regulatory program governing the incidental taking of such sea turtles in the course of such harvesting that is comparable to that of the United States" and an average rate of incidental take of turtles comparable to the U.S. average. The president assigned the development of the certification program to the Department of State. The department's implementing regulations and practices became the focus of discussion in Shrimp-Turtle.

To begin with, the State Department needed to translate into practical guidelines the statutory mandate of Section 609(b) for certification of programs for controlling the "incidental taking of such sea turtles in the course of such harvesting" of wild-caught shrimp that are "comparable" to the United States TEDs program and result in a "comparable" rate of incidental taking of turtles. Formulating guidelines required several interpretive judgments about what the statutory term "such harvesting" means for purposes of comparisons with United States practices. From the outset, the department decided that the certification program does not apply to aquaculture-raised shrimp. ${ }^{79}$ Later, in keeping with refinements of the domestic Shrimp-Turtle policy, it also determined that 609 certification does not apply to artisanal shrimp harvesting using non-mechanical equipment, or to harvesting using gear for which the United States does not require the use of TEDs. ${ }^{80}$ In 1996 guidelines, the United States further expanded the 609 exemption to include imports of certain species of shrimp that are found in waters where sea turtles do not exist. 81

The State Department then needed to define in regulations what would constitute a program "comparable" to the United

79 Turtles in Shrimp Trawl Fishing Operations Protection Requirements, 56 Fed. Reg. 1051 (Jan. 10, 1991).

8058 Fed. Reg. 9015, 9016 (Feb. 18, 1993) (framing as a ground for certification rather than an exemption); 61 Fed. Reg. 17,342, 17,343 (Apr. 19, 1996) (reconfirming as an exemption from the certification requirement).

81 Revised Notice of Guidelines for Determining Comparability of Foreign Programs for the Protection of Turtles in Shrimp Trawl Fishing Operations 61 Fed. Reg. at 17,342, 17,343 (Apr. 19, 1998). 
States program. Once the U.S. program became one that required the use of TEDs by all shrimp trawlers, regardless of size or area of operation, the State Department made two judgments about comparability, one in the regulations and one in its implementing practice. In the regulations, it provided that a comprehensive TED program in another nation "will be" certified as "comparable," 82 and that it would assume a comparable rate of incidental take from such a TED requirement. ${ }^{83}$ In practice, it also made the complementary determination that it would refuse to certify any program that did not contain a U.S.-style comprehensive TED requirement.\&:

Another key State Department decision specified a geographic scope for the 609 certification program and potential embargo, although Section 609 itself contains no geographical limitation. Based in part on what was understood about the ecology of sea turtles found in United States waters and the conservation thrust behind Section 609,85 and in part (presciently but ironically in light of later events) from a desire to avoid trade disruption and foreign policy conflict,86 it determined that "the scope of Section 609 is limited to the wider Caribbean/western Atlantic region."87 It also determined that nations in this region should have three years to phase in the appropriate regulatory programs before the embargo would take full effect, a period of time similar to that afforded United States shrimpers at the beginning of the domestic program. $^{88}$

8258 Fed. Reg. 9015, 9017 (Feb. 18, 1993).

83 Id at 9017. cials).

84 AB Report, supra note 9, para. 162 (citing oral representations of U.S. offi-

s5 56 Fed. Reg. 1051 Jan. 10, 1991).

86 In a 1990 report to Congress on the implementation of Section 609, the Department of State explained its geographical limitation on the scope of the program by noting that a worldwide application could affect shrimp imports from eighty countries with a value of $\$ 1.8$ billion, representing seventy-five percent of all shrimp and shrimp products in the U.S. market. Specifically, the report noted: "In implementing this law, the Administration has proceeded on the assumption that Congress ... did not intend to force a situation that would create enormous market disruptions in the United States and create major foreign policy problems with many countries." Quoted in Earth Island Inst. v. Christopher, 913 F. Supp. 559, 577 (Ct. Int'l Trade, 1995).

8756 Fed. Reg. 1051 (Jan. 10, 1991).

\&s See id. 
The State Department and the National Marine Fisheries Service in the Department of Commerce launched an intensive program to explain the TEDs program to the countries involved, to help them design suitable regulatory programs, and to transfer to them the technology of TED equipment and towing techniques. ${ }^{89}$ This combined effort succeeded fully: at the end of the three-year period, every affected nation in the wider Caribbean/western Atlantic had adopted the necessary laws and regulations, all shrimp trawlers were using TEDs, and every nation in the region was certified under Section 609(b), allowing their imports of shrimp to the United States to continue uninterrupted.90

The State Department also focused its Section 609(a) treaty negotiation efforts on the same western hemisphere region. ${ }^{11}$ In cooperation with Mexico, it initiated hemispheric negotiations on a turtle protection regime in 1993,92 which culminated on December 1, 1996, in the Inter-American Convention for the Protection and Conservation of Sea Turtles, signed by six governments and open for signature to all nations in the Americas. ${ }^{93}$ The Convention,

89 It is with respect to this fully discretionary diplomatic support for the Section 609 program that disparities arose compared to the treatment accorded the Asian complainants in the WTO case. See discussion infra at notes 216-17.

90 However, Honduras was recently "decertified" for failure to enforce its program effectively. Bureau of Oceans and International Environmental and Scientific Affairs, Certifications Pursuant to Section 609 of Public Law, 101-162, 65 Fed. Reg. 25,785, 25,785 (May 3, 2000).

91 Why the Department did so is difficult to say from the public record. Several explanations seem plausible, as discussed infra note 172. The most obvious is that a focus on treaty negotiation in the western hemisphere under Section 609(a) matched the State Department's geographic limitation on the scope of the embargo-certification program under Section 609(b). By the time the treaty negotiations were launched, the western hemisphere countries were well aware of the issues involved thanks to the U.S. educational and technology-transfer campaign. The regional emphasis also corresponded to contemporaneous U.S. foreign policy attention to the western hemisphere, including the Enterprise for the Americas initiative and the negotiation of NAFTA.

92 United States, First Submission, Brief to the WTO Dispute Settlement Panel, para. 30 (June 9, 1997).

93 Inter-American Convention for the Protection and Conservation of Sea Turtles, opened for signature Dec. 1, 1996, entered into force May 15, 2001 [hereinafter Inter-American Convention], available at http://www.seaturtle.org/iac /conventions.html. For the purposes of this Convention, the Americas specifically includes the three European countries-France, Great Britain, and the Netherlands - with island territories in the Caribbean. 
which did not come into force until May 2, 2001,94 takes a comprehensive approach to sea turtle conservation, calling for land-based protection and habitat restoration, the use of TEDs or other improvements in fishing gear, national or regional management plans, and further scientific research and fishing gear development. ${ }^{95}$ Like some other wildlife conservation treaties, it authorizes limited exceptions for "economic subsistence needs of traditional communities," provided that "such exceptions do not undermine efforts to achieve the objective of this Convention." 85

If the scientific concern about sea turtle survival were in fact limited to the wider Caribbean and western Atlantic, the State Department's approach to Section 609 application could be counted a major success in using the threat of trade sanctions in combination with technical assistance and active diplomacy to promote the development of effective international programs to protect and conserve natural resources, and to induce agreement on a longer-range multilateral management regime.97 The worldwide distribution and migratory life habits of sea turtles, however, mean that even a program covering most of the Western Hemisphere cannot protect all sea turtles, not even all sea turtles that spend part of their life in U.S. waters. Insisting on the need for a truly world-wide conservation effort, a U.S. environmental and animal welfare organization, the Earth Island Institute, brought suit to contest the decision to limit the application of Section 609 to the wider Caribbean/western Atlantic region. ${ }^{98}$ After some procedural delays, ${ }^{99}$

94 Recourse Panel Report, supra note 17, para. 2.3.

95 The Inter-American Convention provides that parties "shall take appropriate and necessary measures... for the protection, conservation, and recovery of sea turtle populations and their habitats." Id. art. IV.1. The Convention specifies that such measures "shall include" the variety of approaches mentioned in the text. Id. art III.2

Ss Id. art III.3.a.47.

97 The entire history of Shrintp-Turtle is similar in many respects to the TunaDolphin case, which also included two controversial dispute settlement reports. For a thorough history of Tuna-Dolphin, arguing that unilateral trade measures in that case helped the formation of an effective multilateral regime, see Parker, stlpra note 13.

93 Earth Island first filed their suit in U.S. district court in California. See Earth Island Inst. v. Christopher, 6 F.3d 648 (9th Cir. 1993) (affirming dismissal of the suit by the district court for the Northern District of California for lack of subject matter jurisdiction in view of the exclusive jurisdiction of the Court of International Trade). 
on December 29, 1995, the Court of International Trade ruled on the merits in favor of the environmental plaintiffs and gave the federal government until May 1, 1996 to implement the Section 609 embargo world-wide. ${ }^{100}$ The State Department sought a one-year delay, which the court rejected. ${ }^{101}$ In compliance with the court order, the State Department published a Federal Register notice on April 19, 1996, amending its Section 609 certification program effective May 1, 1996.102

This sudden and, for many, unexpected extension of Section 609 beyond the wider Caribbean precipitated the WTO dispute, initiated by four shrimp-exporting countries newly and almost immediately subject to the shrimp embargo-India, Malaysia, Pakistan, and Thailand. The WTO complainants made a formal request for consultations with the United States as early as October 8, 1996, and the WTO Dispute Settlement Body referred the matter to a dispute settlement panel on February 25, 1997, later consolidating another complaint on April 10, 1997.

The proceedings in the WTO followed a pattern that has become familiar in other disputes. 103 The initial panel proceedings moved expeditiously, resulting in a panel report on May 15, 1998. The United States and the petitioning countries cross-appealed on

99 The district court in California determined that it lacked jurisdiction over the matter because the claims under Section 609(a) "raise issues relating to the foreign affairs function," while those under 609(b) involved restrictions on imports into the United States that were within the exclusive jurisdiction of the Court of International Trade (CIT). Earth Island Inst. v. Christopher, 6 F.3d 648, 650 (9th Cir. 1993), reviewing the holdings of the district court in dismissing the case. The CIT has exclusive jurisdiction over cases under laws providing for "embargoes or other quantitative restrictions on the importation of merchandise for reasons other than protection of the public health or safety" and cases involving the "administration and enforcement" of such laws. 28 U.S.C. 1581(i)(3) and (4) (enacted as part of the Customs Courts Act of 1980, which created the CIT). On October 1, 1993, the Ninth Circuit upheld the district court's dismissal. It was only after this procedural delay of nearly two years that Earth Island, now joined by other environmental groups, re-filed its suit in the Court of International Trade. 1995).

100 Earth Island Inst. v. Christopher, 913 F. Supp. 559, 580 (Ct. Int'1 Trade

101 Earth Island Inst. v. Christopher, 922 F. Supp. 616 (Ct. Int'l Trade 1996).

102 Revised Notice of Guidelines for Determining Comparability of Foreign Programs for the Protection of Turtles in Shrimp Trawl Fishing Operations, 61 Fed. Reg. 17,342 (Apr. 19, 1996).

103 The history that follows derives from the account in the Recourse Panel Report, supra note 17, paras. 1.1-1.5, 2.12-2.22. 
various legal issues to the Appellate Body, which conducted its own proceedings and issued its lengthy report on October 12, 1998. The panel's report and the Appellate Body's report modifying it were accepted as the final decision at a meeting of the Dispute Settlement Body on November 6, 1998. The United States then negotiated with the complaining countries for a period of time to bring itself into compliance with the rulings, and a period of thirteen months was agreed. The United States then proceeded to develop some changes to its practices and its policies on the shrimp-turtle question vis-à-vis the Asian complainants. It proposed "revised guidelines" for implementation of Section 609 on March 25, 1999,104 and adopted final revised guidelines on July 8, 1999.105 In late 1999, the United States and Malaysia reached an understanding about any further proceedings in the WTO, and on October 12, 2000, Malaysia asked for a panel to be formed for a proceeding under Article 21.5 of the Dispute Settlement Understanding for a review of the U.S. implementation of the WTO decision and possible recourse by Malaysia based on a U.S. failure to meet WTO obligations.106 The Recourse Panel issued its report on June 15, 2001. Malaysia appealed, and the Appellate Body issued a report reviewing and upholding the decision of the Recourse Panel on October 22, 2001. Most of the analysis in Section 4 that follows focuses on the 1998 Appellate Body report in the main proceeding, but the analysis will incorporate the interpretation, clarification,

10464 Fed. Reg. 14,481.

10564 Fed. Reg. 36,946.

105 Malaysia was prompted to this action in part by further twists in the domestic legal battles in the United States. In 1996, the Court of International Trade ruled that trawl-caught shrimp could not be imported from non-certified countries even if the trawlers in question had used TEDs. Earth Island Inst. v. Christopher, 942 F. Supp. 597 (Ct. Int'1 Trade 1996). The Federal Circuit vacated those decisions in 1998, and the United States resumed accepting imports of TED-caught shrimp from non-certified countries. In July, 2000, in a new case, the Court of International Trade again found that such imports violated Section 609. Turtle Island Restoration Network v. Mallett, 110 F. Supp. 2d 1005 (Ct. Int'l Trade 2000). The government immediately appealed this decision, and the Court of Interational Trade declined to issue an injunction pending appeal, so TED-caught imports from non-certified countries continue to be allowed. Malaysia argued that the Turtle Island decision made the Section 609 policy inconsistent with Article XX. The United States argued in response, and the panel agreed, that Turlle Islmind was not yet effective law in the United States. Recourse Panel Report, supra note 17, paras. 5.108-5.111. 
and rearticulation of that report in the recent Recourse Panel and Appellate Body reports.

\section{THE SHRIMP-TURTLE INTERPRETATION OF THE CHAPEAU NULLIFIES ARTICLE XX}

\subsection{Overview of the 1998 Appellate Body Report}

The Shrimp-Turtle case, like the Tuna-Dolphin and Reformulated Gasoline cases before it, posed for the WTO the fundamental question of how the "general exceptions" allowed by Article XX fit into the overall purposes of the multilateral trading system. After the Appellate Body's Reformulated Gasoline report, the WTO panel appointed to hear the Shrimp-Turtle dispute understood that the chapeau of Article XX, not paragraph (g), had become the critical test. However, the panel missed the more basic point in Reformulated Gasoline about the proper analytical approach in Article XX cases.107 Ignoring the instruction to decide first if a measure fits within the excepted category defined by paragraph $(\mathrm{g})$, the ShrimpTurtle panel began its analysis by evaluating the U.S. measure in terms of the chapeau conditions. In so doing it reverted to earlier thinking that measures which "undermine the WTO multilateral trading system" must be regarded as "not within the scope of the measures permitted under the chapeau of Article XX."108

Recognizing the sweeping implications of the panel report language, ${ }^{109}$ the Appellate Body begins its discussion of Article $X X$

107 Accord, Howse, supra note 25, at 80-81 ("The panel itself managed to completely misunderstand Reformulated Gasoline.").

$108 \mathrm{AB}$ Report, supra note 9, para. 116 (juxtaposing quotes from paragraphs 7.44 and 7.62 of the Panel Report.)

109 Howse, supra note 25, at 78. This article notes five "fundamental propositions" on which the panel report depends:

- [T]he words "unjustified discrimination," [Howse's usage; it should be "unjustifiable discrimination"] when interpreted in light of the context and purpose and object of Article $X X$, encompass any measure that would undermine the WTO trading system, making unnecessary the identification of a discriminatory element in the ordinary meaning of the word;

- measures undermine the WTO trading system when they undermine the expectations of Members as to the competitive relationship between their products, and jeopardizes the predictability of future trade; 
with a sharp criticism of the panel's reasoning. The Body forthrightly reaffirms its rejection of the traditional GATT approach, reflected in the Tuna-Dolphin cases, that condemned essentially all environmental trade measures because they did not operate directly to address the underlying environmental problem. It recalled that Reformulated Gasoline had laid out a more precise analytical approach to the issue, which asked first whether a measure qualified "provisionally" under paragraphs (b) or (g), and left matters of potential discriminatory effect to the second step in the analysis, namely whether the measure was applied in accordance with the conditions of the chapeau. The Appellate Body then applied the two-step approach in Shrimp-Turtle.

In step one, the Appellate Body determined that Section 609 met the requirements of Article $X X(\mathrm{~g}) .{ }^{110}$ The reasoning on this issue is straightforward, though not uncontroversial. No party disputed that sea turtles are a natural resource. Against legal arguments advanced by the complainants that the turtles are not an "exhaustible natural resource" " because "exhaustible" refers only to finite resources like minerals, not to living, reproducing resources" the Appellate Body invoked modern biological science and the international recognition of the sea turtles" endangered status to conclude that they are "exhaustible."111 It then found the U.S. law to be focused quite narrowly on protection of sea turtles from mortality in shrimp trawling nets and thus "related to" the conservation of the turtles.112 Because the United States had already implemented equivalent measures for shrimping activities

- it is enough that, if the measures of this particular kind or class proliferate, the integrity of the world trading system would be affected;

- measures that condition access for imports on home country regulation undermine Members" expectations as to the competitive relationship between their products ...;

- the US measure complained of is a measure that conditions access for shrimp imports on home country regulation.

Id.

110 AB Report, supra note 9, paras. 125-145.

111 Id. paras. 127-134. Though many WTO Members question this aspect of Shrimp-Turtle, it is consistent with GATT and WTO precedent, including Cmada Salmon and Herring, supra note 61 (fish stocks as exhaustible resources) and Reformulated Gasoline, supra note 64 (clean air as an exhaustible resource).

112 AB Report, supra note 9, paras. 138, 141-42 
under United States jurisdiction, the Body found that the Section 609 shrimp embargo also satisfied the $X X(\mathrm{~g})$ condition that it a measure be taken "in conjunction with" restrictions on domestic production and consumption of the same resource.113 This part of Shrimp-Turtle has drawn the most praise from commentators for its new-found sensitivity to environmental considerations and welcome reliance on sources of public international law outside the WTO.

Having concluded that Section 609 qualified "provisionally" under Article $X X(\mathrm{~g})$, the Appellate Body turned to the second step of the analysis to see if the measure, as applied, also met the requirements of the chapeau. The Appellate Body began this section of its report with a broad discussion of the chapeau as a whole.114 As a provision for "general exceptions," Article $X X$ necessarily imagines that the multilateral trading system zvill tolerate certain national trade measures even though they deviate from, and thus could be said to "undermine," the core obligations of the GATT. On the other hand, the "rights" to the exceptions under Article XX are conditional, and the conditions are found in the chapeau. The Appellate Body developed a general conceptual approach to the chapeau conditions as a prevention against "abuse" of the Article $X X$ exceptions. ${ }^{115}$ The Body's analysis tends toward an interpretation of the chapeau conditions deduced from a presumed general objective. Putting the theoretical discussion first as the Appellate Body does can lead to logical error. The way Article $X X$ is written, however, rather broad exceptions are allowed, so any overarching constraints on exceptions in the chapeau should only be induced from the specific results it precludes. This Article therefore postpones its analysis of this part of Shrimp-Turtle until Section 4.3. infra.

The report of the Appellate Body turned finally to the three component elements of potential abuse of Article $X X$ specified in the chapeau-unjustifiable discrimination, arbitrary discrimination, and disguised restrictions on trade. This part of Shrimp-Turtle first examined the overall context for a finding of discrimination and then identified four discrete respects in which it found that

\footnotetext{
113 Id. paras. 144-45.

114 Id. paras. 148-60; see also infra Section 4.3.1.

115 Id. para. 151 (quoting from Reformulated Gasoline.)
} 
United States policy under Section 609 constituted arbitrary or unjustifiable discrimination.116 Shrimp-Turtle devoted most attention to elements of "unjustifiable discrimination,"117 using the discussion of the separate but closely related standard of "arbitrary discrimination" to reinforce its conclusions about unjustifiable discrimination.118 Section 4.2. analyzes this crucial part of ShrimpTurtle. Section 4.2.1. critiques the Appellate Body's overall frame of reference-or more accurately its lack of a clear frame of reference-for defining discrimination while the remaining subsections of Section 4.2. take up three alleged aspects of discrimination-the coercive effect of an inflexible policy, the failure to engage in systematic efforts at multilateral negotiations, and specific ways in which the Asian complainants were treated differently from western hemisphere shrimp exporters.

In spite of its generous view of the scope of Article $X X(\mathrm{~g})$, and notwithstanding the its effort to take a careful, analytical approach to the chapeau, Shrimp-Turtle continues the tradition of trade jurisprudence that has almost completely closed off the policy space Article $X X$ should leave open for national trade measures designed to protect the environment. Part of the problem is that the Appellate Body fails to comprehend the inherent characteristics of environmental legislation and regulation, so that its tests for nondiscrimination in application of measures under the Article $X X$ chapeau become a proverbial "eye of the needle" through which hardly any national environmental measure will be able to pass. The decision by the panel and Appellate Body in the subsequent recourse proceeding, even while qualifying the United States policy under Article $X X$, confirms this judgment, especially with respect to the supposed requirement for efforts at multilateral negotiations. More ominously, the Shrimp-Turtle analysis, which reads

116 The Appellate Body reached no conclusion on whether Section 609 was a "disguised restriction" on trade. Id. para. 184. Mavroidis remarks that the Appellate Body "eventually avoided" interpreting disguised restriction. Mavroidis, supra note 24, at 80 . That strikes me as too harsh a view. Given the Appellate Body's statement that there was no evidence of lack of good faith on the part of the United States in the exercise of its Section 609 policy, analysis of disguised restriction on these facts would have been problematic. AB Report, supra note 9, paras. 161-76. Since the issue was not important to the outcome, the Appellate Body was wise to leave it aside.

117 AB Report, supra note 9, paras. 161-76.

118 Id. paras. 177-84. 
the provisions of the lettered paragraphs of Article $X X$ broadly but then applies very strict criteria for the conditions of the chapeau, leaves the Appellate Body no analytical escape route in future cases. If the WTO is to give Article $X X$ its rightful place in the overall structure of the multilateral trading system, the Appellate Body, or the membership at large, will need to re-think this interpretation of the chapeau.

4.2. Finding "Arbitrary or Unjustifiable Discrimination between Countries where the Same Conditions Prevail" in the Application of Section 609

To draw the "line of equilibrium" between Article $X X$ rights and other GATT rights, the Appellate Body needs specific criteria or formulas to decide whether the contested measure has been applied in a way that results in "arbitrary or unjustifiable discrimination between countries where the same conditions prevail."119 The language of the chapeau indicates three necessary elements for such a determination: 1) an identification of the relevant "conditions" under which discrimination might occur; 2) a finding that the country taking the measure discriminated in fact or was bound to discriminate in law between two countries (one of which could be the country taking the measure), where relevant conditions were "the same"; and 3) a legal judgment that such discrimination was (or would be) either arbitrary or unjustifiable. In ShrimpTurtle, the Appellate Body identifies these three elements.120 Oddly, though, the Appellate Body fails to articulate a clear finding on the first or third elements: it never identifies the "conditions" it deems relevant, and it offers no legal analysis, separate from its discussion of the facts of the case, of what factors differentiate discrimination that is "arbitrary or unjustifiable" from dis-

119 The chapeau also guards against "disguised restrictions on trade," but that element was mentioned only inconclusively in Shrimp-Turtle, so the discussion in this Article will focus on the "arbitrary or unjustifiable discrimination" elements.

120 The Appellate Body, though, puts the issue of "same conditions" last instead of first. This ordering may account for the vagueness of its analytical approach. By focusing first on the details of the supposed discrimination, it is easy to slip into an incautious assumption that the same conditions prevail without ever determining that issue explicitly. AB Report, supra note 9, paras. 148-60. 
crimination that is not.121 As a result, Shrimp-Turtle exhibits an intense focus on the facts of the allegedly unjustifiable discrimination in the United States policy without a clear indication of just how those facts constituted discrimination and no meaningful legal arguments about why the discrimination was unjustifiable in WTO terms. The report is suffused with the feeling that the points of discrimination against the complainants are so clear that their unjustifiability speaks for itself.

Some lack of clarity in analyzing these points can be excused. The two issues of "discrimination" and "same conditions" tend to collapse into a single consideration of the facts about the nature and context of the alleged or observed discriminatory practice. Moreover, the legal question of whether the discrimination was arbitrary or unjustifiable immediately arises when the facts of the discrimination itself are being considered. Although the chapeau test clearly has three elements, it can be awkward to discuss them sequentially. Therefore, a unitary analysis is not entirely unsuitable. Nevertheless, the decisionmaker needs to articulate a clear framework for the analysis, whether unitary or tripartite. In its brief, the United States proposed an analytical framework, which the Appellate Body bluntly declared "must be rejected." But then the Appellate Body wandered off on a discourse on the general construction of the chapeau and never constructed its own analytical reference points for its findings of unjustifiable discrimination.

The following sections will try to fill the analytical gaps in Shrimp-Turtle. Section 4.2.1. will consider the general contours for an analytical approach. Sections 4.2.2., 4.2.3., and 4.2.4. will apply that approach in the context of the main elements of arbitrary or unjustifiable discrimination that Shrimp-Turtle identifies: that the United States applied its policy with "coercive effect"; that it failed to engage the complainants in negotiations toward a multilateral agreement on turtle protection; and that certain practices in administering Section 609 constituted "arbitrary" discrimination. These sections will show that, leaving aside a few minor elements

121 The Appellate Body tends to emphasize the "unjustifiable" element, using the "arbitrary" element only as a secondary or supporting explanation. To that extent, one can surmise that the Appellate Body feels more confident of its judgment about insufficiency of justification than it does in its judgment of arbitrariness. But it is not altogether clear that it makes a real distinction between the two aspects. 
that came up in the "arbitrary discrimination" analysis, 122 ShrimpTurtle fails to make a logical, fact-based case that the U.S. application of Section 609 discriminated inappropriately against the complainants.

\subsubsection{When is there "Unjustifiable Discrimination between} Countries where the Same Conditions Prevail"?

Whether a measure is applied in a way that is "arbitrary" or "unjustifiable" can only be judged against some standard of rationality that allows distinctions between non-arbitrary and arbitrary choices, or that permits some grounds that might "justify" a particular discriminatory effect. That is, the chapeau text implicitly allows discrimination in the application of a measure if there are circumstances or factors that provide some regular and predictable (i.e., non-arbitrary) basis for its discriminatory effect or support a plausible explanation for the discrimination (i.e., enable it to be justified).

The United States argued in its brief that the environmental policy goal of an Article $X X(\mathrm{~g})$ measure should shape the context for judging whether discrimination is unjustifiable:

In context, an alleged "discrimination between countries where the same conditions prevail" is not "unjustifiable" where the policy goal of the Article XX exception being applied provides rationale for the justification. If, for example, a measure is adopted for the purpose of conserving an exhaustible natural resource under Article $X X(\mathrm{~g})$, it is relevant whether the conservation goal justifies the discrimination .... [A]n evaluation of whether a measure constitutes ... unjustifiable discrimination should take account of whether differing treatment between countries relates to the policy goal of the applicable Article XX exception. If a measure differentiates between countries based on a rationale legitimately connected with the policy of an Article $X X$ exception, rather than for protectionist reasons, the measure

122 See infra Section 4.2.4. 
does not amount to an abuse of the applicable Article $X X$ exception. ${ }^{123}$

The Appellate Body rejects this approach for reasons that can only be characterized as confusing:

We believe [the United States] argument must be rejected. The policy goal of a measure at issue cannot provide its rationale or justification under the standards of the chapeau of Article XX. The legitimacy of the declared policy objective of the measure, and the relationship of that objective with the measure itself and its general design and structure, are examined under Article $X X(\mathrm{~g})$, and the treaty interpreter may then and there declare the measure inconsistent with Article $X X(\mathrm{~g})$. If the measure is not held provisionally justified under Article $X X(\mathrm{~g})$, it cannot be ultimately justified under the chapeau of Article XX. On the other hand, it does not follow from the fact that a measure falls within the terms of Article $X X(\mathrm{~g})$ that that measure also will necessarily comply with the requirements of the chapeau. To accept the argument of the United States would be to disregard the standards established by the chapeau. ${ }^{124}$

\section{What sense can we make of this paragraph?}

Recall that the general logic of the Appellate Body's approach to the evaluation of a disputed environmental trade measure under Article $X X$ begins with an assessment of whether the measure was "necessary" for the protection of life or health under $X \times(b)$ or "related to" the conservation of resources under $X X(\mathrm{~g})$. Provisional acceptance of the measure under one of those paragraphs requires a rational relationship between the effect of the measure and its environmental objective. So the Appellate Body is clearly correct in saying that the policy objective of the measure is examined under XX(g) and that a measure might be "then and there" declared outside the scope of the Article $X X$ exceptions. If a measure does not provisionally qualify under (b) or (g), that is the end of the

123 Brief of the United States, quoted in AB Report, supra note 9, para. 148.

124 Id. para. 149. 
matter, without any consideration of the chapeau conditions. It is absurdly redundant for the Appellate Body to point out that measures that do not "provisionally qualify under one of the paragraphs" cannot "ultimately" meet the Article XX qualifications by reference to the chapeau. It is equally obvious that qualification under (b) or ( $g$ ) does not automatically qualify the measure under the chapeau. The issues to be determined under the chapeau are an additional control on national action distinct from those under (b) or (g). Under $X X(\mathrm{~g})$ analysis, a measure, whether discriminatory or not, is examined simply to judge if it is part of an overall program that relates to conservation of an exhaustible resource. The chapeau, on the other hand, does not focus on the broad objectives of an environmental law nor on the merits of any of its provisions, but on whether some specific aspect of its application gives rise to trade discrimination that is "arbitrary" or "unjustifiable." The Appellate Body itself underscored this point in Reformulated Gasoline. ${ }^{125}$

But the Appellate Body's assertion that the "policy goal of a measure at issue cannot provide its rationale or justification under the standards of the chapeau of Article XX" does not follow logically from the preceding points. If the policy goal of the measure cannot be the reference point for justifiability of discrimination, what can be? It is difficult to imagine other criteria by which to evaluate arbitrariness or unjustifiability, and the Appellate Body offers none. Could the Appellate Body, subliminally, be saying that there is never a justification for discrimination? That would be contrary to the Article $X X$ text, which precludes not all discrimination but only discrimination that is "arbitrary or unjustifiable." To assert or imply that any discrimination ipso facto arbitrarily or unjustifiably impairs trade rights would contradict not simply the GATT text but the reality that some discrimination is actually to be desired in the application of measures lest any national measure become a universal and indiscriminate trade barrier.

The chapeau itself creates no independent "standards" or requirements. As discussed in more detail below, 126 the chapeau is not a free-standing statement but a subordinate clause that takes its

125 Reformulated Gasoline, supra note 64, at 22.

126 See infra Section 4.3. (arguing that the chapeau should not be viewed separately from the lettered paragraphs of Article XX). 
meaning from the rest of the sentence that follows the lettered paragraphs of Article XX. In other words, the chapeau puts certain threshold conditions on the exercise of the rights granted in the separate paragraphs of the article. In essence, it imposes a reasonableness standard for the possible trade-discriminatory effects of national policy. In this light, the Appellate Body is wrong to claim that following the U.S. approach "would be to disregard" the chapeau. Quite the opposite: the United States approach acknowledged the justifiability of discrimination as a separate requirement and proposed a frame of reference for assessing justifiability with respect to the particular facts of the case.

The chapeau by its own terms sets one important parameter: discrimination inconsistent with the chapeau conditions can occur only between countries "where the same conditions prevail." Implicit in the "same conditions" proviso is an allowance for discrimination in an Article $X X$ measure between any two trading partners based on differences in conditions. At the threshold, then, the WTO needs a jurisprudence to decide which "conditions" are pertinent and when they can be deemed to be "the same." Each nation in the world is unique; it is impossible that all conditions might be the same in any two countries. In the trade context, however, it would be preposterous to argue from that premise that the "same conditions" never prevail. An effective interpretation of the chapeau, therefore, needs to establish a context for deciding which conditions to compare in judging the application of a national measure. It would be senseless for the comparison to focus on conditions that have no relationship to the purposes for which the trade measure was instituted. For example, the United States should not be allowed to discriminate between two countries under Section 609 on the basis of the number of television sets per household. The only principled basis on which to select the relevant conditions for comparison is that they should have something to do with the declared objectives of the measure-in this case, something to do with shrimp fishing and sea turtle protection. The Appellate Body's provisional acceptance of Section 609 under Article $X X(\mathrm{~g})$ depended on its finding a rational relationship between the operation of Section 609 and its turtle-protection objective. The test for discrimination under the chapeau ought to be congruent with that rational relationship, looking at the similarity of those conditions in each country that have some relevance to the envi- 
ronmental policy objectives of the measure in question. That was the thrust of the United States proposition in its brief.

Ample precedent supports such an approach to the issue of "same conditions." For example, the WTO has developed a flexible interpretive approach to the analogous issue of whether or not two products are "like."127 The WTO's contextual approach to the interpretation of very similar language in Article 2.3 of the Agreement on the Application of Sanitary and Phytosanitary Measures (the SPS Agreement) is even more pertinent.128 The nearly identical language in GATT Article XX and Article 2.3 of the SPS Agreement reflects their similar goals. ${ }^{129}$ It is well understood that SPS measures, which by their nature concern themselves with conditions in countries where agricultural goods or food products originate, will frequently violate one or both of the GATT's main nondiscrimination obligations - national treatment or most-favorednation. Article $X X$ was crafted in part to shield national SPS meas-

127 See Appellate Body, Japan-Taxes on Alcoholic Beverages (Oct. 4, 1996), $W T / D S 8 / A B / R, W T / D S 10 / A B / R, W T / D S 11 / A B / R$, at 20. The Appellate Body invokes a picturesque analogy:

The concept of "likeness" is a relative one that evokes the image of an accordion. The accordion of "likeness" stretches and squeezes in different places as different provisions of the WTO Agreement are applied. The width of the accordion in any one of those places must be determined by the particular provision in which the term "like" is encountered as well as by the context and the circumstances that prevail in any given case to which that provision may apply.

Id.

128 Article 2.3 of that agreement provides:

Members shall ensure that their sanitary and phytosanitary measures do not arbitrarily or unjustifiably discriminate between Members where identical or similar conditions prevail, including between their own territory and that of other Members. Sanitary and phytosanitary measures shall not be applied in a manner which would constitute a disguised restriction on international trade.

Agreement on the Application of Sanitary and Phytosanitary Measures, April 15, 1994, Marrakesh Agreement Establishing the World Trade Organization [hereinafter WTO Agreement], Annex 1A LEGAL INSTRUMENTS-RESULTS OF THE URUGUAY RouND vol. 6; 33 I.L.M. 1153 (1994) [hereinafter SPS Agreement].

129 At the time GATT was negotiated in 1947, trade law had no provision comparable to the SPS Agreement. Steve Charnovitz, Exploring the Environmental Exceptions in GATT Article XX, $25 \mathrm{~J}$. WORLD TRADE 37, 38 (1991). In substantial part, Article $X X$ was included to authorize national SPS measures but to impose some constraints on how they were applied. Id. at 52 . 
ures from challenge on trade discrimination grounds. ${ }^{120}$ Article 2.3 in the WTO SPS Agreement similarly guards against SPS discriminations that are not related to the objective behind the measure. The "same conditions" language clearly refers to conditions relevant to the health or agriculture protective purposes of the national measure at issue. ${ }^{131}$

Using the same analytical approach to discrimination under Article $X X(\mathrm{~g})$, a trade measure to conserve an exhaustible natural resource should be able to discriminate between different nations depending on such conservation-relevant factors as whether the resource exists in the nation and whether its conservation programs and practices for the resource are consistent with the policies for conserving the same resource in the country taking the measure. Indeed, the better argument is that such conservationrelevant factors should be the only permissible bases for differentiation. No other conceivable similarities or differences in conditions from one country to the next, including social values or economic conditions, bear a direct relationship to the conservation

130 Id.

131 Consider two recent high-profile measures relating to beef imports in the European Union ("EU"). In the case of bovine spongiform encephalopathy ("BSE"), the EU adopted a measure restricting the shipment of certain beef products to protect human health from Creutzfeld-Jakob disease. The only "conditions" that mattered were the presence of BSE infection in cattle or slaughtered beef in the country of origin. For several years, BSE was known to be present only in the beef supply of the United Kingdom, so British beef was banned from shipment to other European countries, while beef from other countries not otherwise notably different from the United Kingdom, such as the Netherlands or Germany, continued to be traded across borders. In the WTO beef hormone case, the policy concern behind the EU action was human exposure to artificial hormones. The relevant "condition" was the non-therapeutic use of hormones to promote growth in beef cattle, a practice common in the United States and Canada but illegal in Europe. Therefore, the EU embargoed American and Canadian beef, while beef from other major exporting countries was allowed in. Report of the Appellate Body, EC Measures Concerning Meat and Meat Products (Hormones), WT/DS28/AB/R \&WT/DS46/AB/R, Jan. 161998 [hereinafter Bref Hormones]. In both cases, of course, there continues to be tremendous political and legal controversy about the measures because of disputes over their scientific basis, but to the best of my knowledge neither the United Kingdom in the BSE case nor the United States in the hormones case claimed that the EU measures "discriminated" against them impermissibly because the "same conditions" prevailed between the United Kingdom or the United States on the one hand and the other WTO members whose beef products continued to be imported into Europe. The "discrimination" inherent in selective application of SPS measures to particular countries had its justification in the policy goals for which the import restrictions were adopted. 
purposes of the measure. A turtle-protective shrimp embargo that discriminated, for example, between shrimp from Malaysia and shrimp from the Dominican Republic on the basis of their different economic conditions would be "unjustifiable." That is not to say that international environmental policy should not, as the Rio Declaration puts it, consider the "differentiated responsibilities" of countries based on their developmental status.132 Certain aspects of trade policy also make or permit distinctions between countries in terms of economic development. ${ }^{133}$ But an economically-based discrimination should be virtually impossible to justify for an environmental trade measure under the chapeau of Article XX.

Indeed, WTO members have repeatedly expressed this point of view in the Committee on Trade and Environment debates over the relationship between Article $X X$ and multilateral environmental agreements ("MEAs"). Virtually every member espouses the view that the WTO-consistency of the application of a trade measure in an environmental agreement should depend fundamentally on the substantive compliance status of the target government vis-a-vis the objectives and implementing provisions of the agreement. The target government's formal party status (that is, whether it has legally bound itself to the treaty) should be irrelevant. Similarly, most governments are of the view that an environmental trade measure in a multilateral environmental agreement should not make trade conditions dependent on a nonenvironmental consideration such as the membership of the exporting nation in the Organization for Economic Cooperation and Development. Rather, recourse to a trade restriction should turn on some objective criteria related to the environmental risks involved or the environmental performance desired.

132 United Nations Conference on Environment and Development: Rio Declaration on Environment and Development, Principle 7, 31 I.L.M. 874, 878 (1992) ("In view of the different contributions to global environmental degradation, States have common but differentiated responsibilities.") [hereinafter Rio Declaration].

133 One of the most well-known of such differentiations is the Generalized System of Preferences ("GSP"), allowing developed countries to grant preferential trade status to the poorer of the developing countries. For one of several ministerial decisions reached in conjunction with the Final Act of the Uruguay Round, see Decision on Measures in Favour of Least-Developed Countries (April 15, 1994) WTO Agreement, Part III, 33 I.L.M. 138 (1994) (reaffirming a 1979 decision to create the GSP). 
The argument can and should be taken further: Article $\chi X$ measures must, in most cases, discriminate among trading partners. If discrimination in application of an environmental trade measure were not allowed, a national measure like the United States shrimp embargo would have to be applied world-wide, which would make it an over-broad restriction on trade. In its analysis of Section 609 for provisional qualification under $\chi \chi(\mathrm{g})$, the Appellate Body commented with approval that 609 was "not a simple, blanket prohibition of the importation of shrimp imposed without regard to the consequences (or lack thereof) of the mode of harvesting employed upon the incidental capture and mortality of sea turtles." 134 Control of such imports would have had no rational relationship to sea turtle conservation, and would thus have been assumed to be an economic protection measure rather than an environmental measure. Precisely because the Section 609 embargo was not applied to imports of shrimp species not associated with sea turtle habitat, aquaculture shrimp, and artisanal harvesting methods, the Appellate Body concluded that it was "not disproportionately wide in its scope and reach in relation to the policy objective of protection and conservation of sea turtle species." ${ }^{133}$ In other words, such "discrimination" in application was not only "justifiable," it was essential to avoid disqualifying Section 609 as a disguised restriction on trade. Finally, the Appellate Body itself provisionally accepted under $X \times(\mathrm{g})$ the core element of discrimination in the United States program - the allowance of shrimp imports from countries requiring TEDs and the embargo on shrimp from countries not requiring TEDs.

In sum, the Appellate Body lacked any reasoned basis or legal foundation for its out-of-hand dismissal of the United States argument. Just as the United States advocated, the conservation objective of a program provides the most appropriate context for judging whether there was discrimination in its application or whether the discrimination was rational and justifiable.

Having rejected the United States approach, the Appellate Body put forward no discernible principles of its own as an alternative. Most of the discussion of arbitrary and unjustifiable discrimination in Shrimp-Turtle proceeds without any coherent deter-

134 AB Report, supra note 9, para. 141.

135 Id. 
mination that the United States was in fact discriminating at all between countries where the same conditions prevail. That is not surprising in light of the fact that the TED-only program devised by the United States and implemented in all waters and to all shrimp trawlers under United States jurisdiction had also been universally adopted, and shown effective, throughout the Gulf of Mexico, the Caribbean Sea, and the western Atlantic as far as Brazil. That took away from the Asian complainants most grounds for claiming that there had been discrimination against them compared with other countries exporting shrimp to the United States. The demonstrated suitability of TEDs in all these different waters should establish a high threshold of evidence for any argument that conditions in South Asia are different in some way that is meaningful for shrimp fishing equipment and practices and the conservation of sea turtles. The record of the WTO proceeding shows much argumentation but little clear evidence that there is any difference between the shrimp harvesting conditions prevailing in the United States and those in South Asia that is pertinent to the legitimate goal of protecting sea turtles from incidental mortality from shrimp trawling.

In the end, the Shrimp-Turtle analysis of arbitrary and unjustifiable discrimination turned the "same conditions" proviso on its head. Harping on the "coercive" United States insistence that other countries must adopt laws or regulations requiring TEDs to have their programs certified and their shrimp accepted for import, the Appellate Body found that inflexible approach impermissible under the chapeau of Article $X X$, not because it discriminated between countries where the same conditions prevail, but because it refused to discriminate in trade treatment between countries where different conditions may prevail.136 This is the exact converse of the chapeau language, as the Appellate Body essentially confesses:

136 In theory, such a refusal to discriminate could be equally offensive in trade terms. In the BSE example used earlier, for example, suppose the EU blocked shipments of beef from Greece as well as the United Kingdom. Greece might argue that its beef should not be treated that same as British beef, because the prevailing BSE conditions in Greece are different. But in such a case the true Article $X X$ argument is still available and would actually be stronger that such a policy would have discriminated against Greek beef compared with, let us say, beef from Spain or Australia even though the same BSE-free conditions prevail in all those countries. 
"We believe that discrimination results not only when countries in which the same conditions prevail are differently treated, but also when the application of the measure does not allow for any inquiry into the appropriateness of the regulatory program for the conditions prevailing in those exporting countries." 137 Note that the Appellate Body never clarified which conditions it had in mind when it condemned the uniformity of the United States policy approach, nor did it identify the conditions of the Asian countries that were supposedly different. Lacking clear legal guidance, the Recourse Panel reduces the issue of discrimination to a simplistic truism that robs Article XX of any meaning: "In other words," it declares, "the United States failed to pass the "unjustified discrimination" test by applying the same regime to domestic and foreign shrimp."138 By the Recourse Panel's reckoning, then, the uncritical assumption that domestic and foreign conditions must be "different" automatically makes any uniformly applied national measure unjustifiably discriminatory and therefore beyond the pale of Article $X X$. The patent absurdity of such an outcome renders the reasoning "abhorrent." 139 Similarity or difference in conditions for Article $X X$ purposes must mean something more than the always-present distinction between domestic and foreign. This forces us back to the question about just which conditions to compare.

The Panel Report recounted in exhaustive detail the sharply different views of the parties on the environmental policy justifica-

137 AB Report, supra note 9, para. 165. The Appellate Body here overstates the rigidity of the United States system, which excluded from the embargo all farmraised shrimp, shrimp caught with artisanal techniques, and shrimp from waters where sea turtles do not occur. For all other commercial fishing of shrimp, though, the United States applied expert judgment to reach a general regulatory conclusion that TEDs were the only effective measure regardless of other local factors.

138 Recourse Panel Report, supra note 17, para. 5.46.

139 The word comes from the Appellate Body itself, in warning against any interpretation that would totally negate Article $X X$ :

It is not necessary to assume that requiring from exporting countries compliance with, or adoption of, certain policies... prescribed by the importing country, renders a measure a priori incapable of justification under Article XX. Such an interpretation renders most, if not all, of the specific exceptions of Article $X X$ inutile, a result abhorrent to the principles of interpretation we are bound to apply.

AB Report, supra note 9, para. 121. 
tion of a TEDs requirement in Asian waters, ${ }^{140}$ but the Appellate Body made no reference to this and articulated no view of its own. As argued above, 141 the policy goal behind the measure and its application ought to inform the selection of the relevant conditions to compare.

In simplified terms, the United States practice insisted that only two conditions were relevant: 1) the presence of sea turtles in most of the waters where shrimp trawling occurs and 2) the agreed effectiveness of TEDs in reducing incidental turtle mortality from shrimp trawling and the absence of scientific evidence that any other measure was equally effective in conserving sea turtles. From these two conditions, the United States derived the presumptive policy that only the systematic use of TEDs in waters where sea turtles may be present would be "comparable" in turtleprotecting effect to the domestic TEDs requirement. As a matter of environmental policy, this was not an unreasonable approach to implementing the technology emphasis of Section 609, which called for an embargo on shrimp "which have been harvested with commercial fishing technology which may affect adversely such species of sea turtles." 142 Once these statutory policy objectives are accepted as legitimate under Article $X X(\mathrm{~g})$, it is difficult to accept the judgment that it was "unjustifiable" for the State Department regulations to take such a clear-cut, objective policy approach. As a matter of both GATT interpretation and environmental policy, refusal to discriminate across conditions that are only nominally different is not a sound basis on which to disqualify the Section 609 program under the chapeau of Article $X X$. At the very least, the Appellate Body needed to make a robust finding of fact that the shrimp fishing and sea turtle conditions in South Asian waters were different from those in the Caribbean or western Atlantic in ways that were significant for policies to reduce sea turtle mortality.

The Shrimp-Turtle application of the Article $X X$ chapeau to disqualify the U.S. policy because of the refusal to discriminate among nations with arguably different conditions has profound trade-

140 Panel Report, supra note 7, paras. 5.1-5.432.

141 See text accompanying notes 127-29.

142 Act of Nov. 21, 1989, Pub. L. No. 101-162, § 609 (b)(1), 16 U.S.C. $\$ 1537$ (2000). 
environment policy implications. Consider how the Appellate Body must have reasoned to its "unjustifiable discrimination" conclusion. It affirmed the judgment of experts that TEDs are an effective device for the conservation of sea turtles, and it raised no doubt that they would be as effective in South Asian waters as they are elsewhere. ${ }^{143}$ It did not question the GATT-legitimacy of the United States statutory standard for certification: that national programs provide "comparable" and "equally effective" protection of sea turtles from mortality due to commercial shrimp trawling.194 Nevertheless, the Appellate Body somehow reached a conclusion that "equally effective" sea turtle conservation in South Asia might be achievable under different policies that would not include a comprehensive TED requirement. Only on this basis could it have concluded that the State Department's blanket (thus nondiscriminatory) presumptive requirement for the use of TEDs in all nonartisanal shrimp trawling represented an "unjustifiable" discrimination against the South Asian complainants. Slirimp-Turtle thus creates a veritable Catch-22: the blanket requirement for use of TEDs, being "directly connected with the policy of the conservation of sea turtles," brings Section 609 within the scope of $X \times(\mathrm{g}),{ }^{145}$ yet that very same policy cannot meet the chapeau conditions because it precludes decision makers from differentiating among trading partners based on more refined evaluations of their respective turtle conservation programs taking into account unspecified differences in their circumstances.

Before the Appellate Body condemned as "unjustifiable" the "rigid and unbending" insistence on TEDs, it should have considered whether there is a justification for it from an environmental policy perspective. Reasonable people and reasonable governments can and do differ about what turtle conservation policy to select. The United States decided within its own jurisdiction to make TEDs obligatory, a policy choice that the Appellate Body ac-

143 The Appellate Body quotes, with approval, the statement of the Panel that it "did not question ... the fact generally acknowledged by the experts that TEDs, when properly installed and adapted to the local area, would be an effective tool for the preservation of sea turtles." AB Report, supra note 9, para. 140, quoting from Panel Report, supra note 7, para. 7.60, note 674.

$144 A B$ Report, supra note 9, para. 140 (noting those requirements in the context of a paragraph upholding the qualification of the U.S. policy under Article $X X(g))$.

145 Id. para. 140. 
knowledges to be valid in the domestic context.146 The United States also decided, as a matter of legislative policy that the Appellate Body also found provisionally acceptable under $X X(g)$, that other countries wishing to sell their shrimp in the United States should have "comparable" and equally effective programs to protect sea turtles from shrimp harvesting activities. The State Department, in consultation with marine science and management experts at the National Marine Fisheries Service, made a regulatory determination, based on its legal understanding of the term "comparable" and on its scientific assessment of what we know and do not know about sea turtles and means to protect them, that the only program that could be considered comparable and equally effective would be a program that also required the use of TEDs. Since TEDs are about ninety-five percent effective in allowing turtles to escape from shrimp nets, this is not an "arbitrary" or "unjustifiable" conclusion, even if other conclusions might also be reasonable.

Undoubtedly, considerations of administrative capacity also played a part in the State Department's decision, just as they did in adopting the domestic TED-only rule, but such considerations are not impermissible under trade jurisprudence. ${ }^{147}$ A policy requiring each nation simply to mandate use of TEDs on all shrimp trawlers makes it quite easy for the United States to evaluate the other nation's program in terms of its turtle-protecting effectiveness. Whether alternative policies, such as limiting trawling seasons or closing certain areas to trawling would be "equally effective" would be matters of complicated and debatable scientific judgment, requiring collection, validation, and assessment of data that might not be readily available or would be expensive to obtain. Alternative policies would also be more difficult for implementing governments to monitor and enforce, raising further controversial questions for the United States about their "comparability" and their "equal" effectiveness as turtle conservation strategies. On a variety of grounds, therefore, the simplified approach that all countries require TEDs on all trawlers as a condition of certifica-

146 "It may be quite acceptable for a government, in adopting and implementing a domestic policy, to adopt a single standard applicable to all its citizens throughout that country." Id. para. 164.

147 Asbestos, supra note 19, para. 169. 
tion was not at all arbitrary or unjustifiable. It could not have survived as a national policy under United States law if it had been.145

The WTO has a legitimate reviewing role to prevent abuse or deception in Article $X X$ measures. Absent some imputation of bad faith or an effort to disguise trade restrictions, however (and Shrimp-Turtle never suggested a lack of good faith on the part of the United States in applying its policy), the issue for the WTO really reduces to one of whether the national resource conservation policy being examined has been applied reasonably and evenhandedly. The Appellate Body put forward no specific argument that the United States policy choices were patently unreasonable or without scientific foundation. Its own apparent belief that a universal TEDs requirement is not essential to sea turtle conservation may also be reasonable, but it is not and should not be the role of the WTO Dispute Settlement Body to substitute its environmental policy judgment for the not-unreasonable policy judgment of a WTO member. To be precise, the chapeau uses the word "unjustifiable," not "unjustified." Discrimination only fails the chapeau test if one cannot reasonably explain its basis. The Appellate Body need not agree that the discrimination is justified.149 The chapeau sets a somewhat lower and more objective burden-of-persuasion threshold-that the defending government offer an argument by which it is reasonably "able" to justify the discrimination.

The Appellate Body's implicit and unsubstantiated conclusion that policy-relevant differences exist between the conditions in the complaining nations and conditions in the United States creates the further danger that the WTO will become the final arbiter of the environmental merits of United States policy. To have the Appellate Body second-guessing a member's environmental policy takes the WTO well beyond the reach of its limited expertise in environmental protection. Shrimp-Turtle reveals this risk. The Appellate Body failed to consider, for example, the support the U.S. policy draws from the widely-recognized "precautionary approach," which legitimizes cost-effective policy choices to protect the environment even in the absence of scientific certainty about the need

148 See Administrative Procedure Act, 5 U.S.C. \$ 706(2) (2001) (requiring reviewing courts to "hold unlawful and set aside agency action ... found to be (a) arbitrary, capricious, an abuse of discretion, or otherwise not in accordance with law").

149 Panel Report, supra note 7. 
for the measures. ${ }^{150}$ More broadly, Shrimp-Turtle showed insufficient deference to good-faith decisions by a Member. The Appellate Body, a politically insular decision maker with no environmental expertise and not politically accountable, overrode reasonable environmental policy choices forged in the crucible of democratic domestic procedures. "Mysterious . . . unaccountable ... bureaucrats" in Geneva rode roughshod over hard-fought environmental policy choices made by "our" government ${ }^{151}$ - the very specter raised by the oft-scorned environmentalist critics of the WTO. A chapeau interpretation that leads to such a result erodes the public confidence that provides the foundation for an effective WTO and an energetic policy of trade liberalization.

In the recourse proceedings, the Appellate Body stepped back from any WTO role as the scientific arbiter of the fairness of the U.S. practice in reviewing certification applications from other countries.152 Malaysia argued that the U.S. guidelines were not flexible enough under Article $X X$ because they "do not provide explicitly for the specific conditions prevailing Malaysia." Malaysia's specific complaint seems to be that Malaysian boats do not trawl for shrimp specifically, but trawl for fish and harvest shrimp as "by-catch." The Appellate Body declines to get into the specifics of Malaysia's situation, and contents itself with setting forth the discretionary elements of the U.S. guidelines.

[I]n our view, a measure should be designed in such a manner that there is sufficient flexibility to take into account the specific conditions prevailing in any exporting Member, including, of course, Malaysia. Yet this is not the same as saying that there must be specific provisions in the measure aimed at addressing specifically the particular conditions prevailing in every individual exporting Member. Article XX of the GATT 1994 does not require a Member to

150 The "precautionary approach" or "precautionary principle" is itself a slippery concept, but reference to it in the Rio Declaration gives it some stature as a legitimate legal benchmark. Rio Declaration, supra note 132, Principle 15. More generally, see DAVID FREESTONE, THE PRECAUTIONARY PRINCIPLE IN INTERNATIONAL ENVIRONMENTAL LAW (1996).

151 Advertisement, N.Y. TIMEs, April 20, 1992, at B5. Fifteen nonprofit organizations placed the advertisement. Id.

152 AB Recourse Report, supra note 23, para. 145. 
anticipate and provide explicitly for the specific conditions prevailing and evolving in every individual Member. ${ }^{153}$

\subsection{2. "Intended and Actual Coercive Effect" as "Unjustifinble Discrimination"}

Calling it "[p]erhaps the most conspicuous flaw," the Appellate Body claimed that because the United States Shrimp-Turtle policy had an "intended and actual coercive effect on the specific policy decisions made by foreign governments" it resulted in unjustifiable discrimination..$^{154}$ Two intertwined thoughts, it seems prompted this conclusion. On the surface, the Appellate Body faulted the "rigid and unbending" 155 application of the statutory certification conditions, through which foreign countries were essentially required to adopt a turtle protection policy identical to the United States policy in order to avoid the embargo. The strong condemnation of "coercive effect" also seems inspired by the general WTO resistance to the use of trade measures to pressure other governments to adopt policies preferred by the country applying the trade pressure. 156

The Appellate Body, as noted, did not provide a clear analytical roadmap to its conclusion, but it apparently proceeded on the basis of an appropriate distinction between the statute itself, Section 609, and the application of that law. As to the statute itself, the Appellate Body found that it meets the conditions of Article XX(g), and it also appeared to conclude that the law, as written, it is not inconsistent with the chapeau. This interpretation finds support in the recourse proceedings. There the Appellate Body states that the Recourse Panel "rightly concluded that our ruling ... with respect to the consistency of Section 609 ... still stands," 157 and goes on to declare that the "task of the [recourse] Panel with respect to Section 609 ... was limited to examining its application. "15s

\footnotetext{
153 Id. para. 149 (emphasis in original).

154 AB Report, supra note 9, para. 161.

155 Id para. 163.

156 See, e.g., Tuna-Dolphin II, supra note 60, para. 4.12

157 AB Recourse Report, supra note 23, para. 96.

155 Id. para. 98.
} 
Shrimp-Turtle thus focuses on the application of the law by the United States Department of State. The application of the law, though, also has two dimensions that the Appellate Body acknowledges but does not distinguish between in its analysis.159 One dimension is the written "guidelines" for application of Section 609 prepared and published by the State Department; the other is the unwritten "practice" of the department in its interpretation and administration of those guidelines. These two levels of the application of the law merit separate consideration in assessing the WTO's judgment. It is standard in WTO jurisprudence to distinguish between those manifestations of policy that require discriminatory treatment and those that merely allow such treatment. In the case of legal requirements, they can be found inconsistent with WTO obligations, even if they have not yet been applied in a way that results in discrimination, because it is the existence of the measure, and its possible influence on the behavior of others, that offends the trading regime.160 In the case of discretionary measures, however, the WTO will assume that they will be applied in a way that is compatible with the member's obligations, so they will be held inconsistent only if they have actually been applied in an impermissible manner. ${ }^{161}$ The Shrimp-Turtle holdings on the "actual and intended coercive effect" of the application of Section 609 should be assessed for their adherence to those general legal principles.

Although it was not entirely clear from Shrimp-Turtle, the Appellate Body makes clear in its recourse report that it does not question the U.S. effort to induce other governments to adopt sea turtle conservation policies. Malaysia argued in the recourse proceeding that the U.S. program under Section 609 "results in 'arbi-

159 The Recourse Panel Report, for example, notes, "The Appellate Body opposed the text of Section 609 on the one hand and the implementing guidelines and the practice of the United States authorities on the other..." Recourse Panel Report, supra note 17, para. 5.91 (emphasis added).

160 For an exhaustive consideration of these points, see Report of the Panel, United States-Sections 301-310 of the Trade Act of 1974, WT/DS152/R (Dec. 22, 1999).

161 Id. (narrowing this general rule in the specific case, but accepting definitive administrative commitments not to act contrary to WTO obligations as overcoming a prima facie finding that the statute in question, though facially discretionary, impermissibly threatened other states with action inconsistent with the WTO regime). 
trary or unjustifiable discrimination' because it conditions access to the United States market on compliance with policies and standards 'unilaterally' prescribed by the United States." The Appellate Body specifically recalled its statement in the main report that "conditioning access to a Member's domestic market on whether exporting Members comply with, or adopt, a policy or policies unilaterally prescribed by the importing Member may, to some degree, be a common aspect of measures" under the lettered paragraphs of Article XX. The Appellate Body then strongly confirms that conclusion: "this statement expresses a principle that was central to our ruling in United States - Shrint." 162 The Appellate Body has thus put itself clearly on record, for the first time, that a measure is not disqualified under Article $X X$ merely because it is imposed unilaterally by the importing country.

The focus, then, is on the application of the certification program in a way that required governments, if they wished to avoid the embargo, to adopt the specific measure of requiring TED technology on all shrimp trawlers in their waters. Shrimtp-Turtle hinted that the legislative language of Section 609, which requires turtle conservation programs "comparable" to the U.S. program and resulting in a "comparable" rate of incidental take, might have passed muster under the "unjustifiable discrimination" test because it had elements of discretion and flexibility. The Recourse Panel adopts this view, saying that it "seems" that the Appellate Body accepted - at least implicitly - that the comparability language of Section 609 was compatible with the chapeau conditions. ${ }^{163}$ The Appellate Body, in its recourse report, then further clarifies that a measure like Section 609 that calls on exporting countries to adopt measures "comparable in effectiveness" is acceptable under Article XX. In its earlier report, it had been particularly concerned that the U.S. practice seemed to require exporters to adopt measures that were "essentially the same." On the basis of the distinction between sameness and comparability, the Appellate Body now affirms: "As we see it, the Panel correctly reasoned and concluded that conditioning market access on the adoption of a programme contparable in effectiveness, allows for suf-

162 AB Recourse Panel Report, supra note 23, para. 138.

163 Recourse Panel Report, supra note 17, para. 5.93 (citing AB Report, supra note 9, para. 161). 
ficient flexibility in the application of a measure so as to avoid 'arbitrary or unjustifiable discrimination."'164 This holding is expressed despite the fact that the revised U.S. guidelines being reviewed in the recourse proceeding maintain a strong presumption that TEDs will need to be required on trawl nets:

Where standard otter trawl nets are used in shrimp fisheries where sea turtles are present, sea turtles will inevitably be captured and drowned. The Department of State is presently aware of no measure or series of measures that can minimize the capture and drowning of sea turtles in such nets that is comparable in effectiveness to the required use of TEDs. 165

In other words, the Appellate Body has adopted a posture of allowing the country taking an Article XX measure to express presumptions in favor of "same" regulatory approaches so long as it leaves open the possibility and the process for an exporting country to rebut that presumption based on scientific evidence about different local conditions. That possibility was, in fact, always there in the U.S. program. The revised guidelines simply state it more clearly and define the process for making decisions more explicitly. Just how discretion and flexibility in applying statutory standards avoids unjustifiable discrimination is not obvious, but that is a separate point to which we return later. Just how discretion and flexibility in applying statutory standards avoids unjustfiable discrimination is not obvious, but that is a separate point to which we return later. ${ }^{166}$

In its main Shrimp-Turtle report, Appellate Body made a special point that the executive branch's implementation of Section 609 "effectively eliminated" the statutory flexibility and made the United States program "an economic embargo which requires all other exporting Members ... to adopt essentially the same policy [as the United States domestic policy]." 167 Here, though, it is often un-

164 AB Recourse Report, supra note 23, para. 144 (emphasis in original).

165 Id.

166 See infra text accompanying notes 219-25.

167 AB Report, supra note 9, para. 161 (emphasis in original). 
clear whether the Appellate Body is taking issue with the published guidelines or with the informal practice of the officials at the State Department. For example, the Appellate Body especially criticized the "rigid and unbending standard by which U.S. officials determine whether or not countries will be certified," which it believed excluded consideration of "[o]ther specific policies and measures that an exporting country may have adopted for the protection and conservation of sea turtles...."16s However, the 1996 guidelines are not necessarily that constrictive.

In the Recourse Panel Report, the WTO panel concludes that the revised guidelines that the State Department issued after the Appellate Body decision are compatible with the Appellate Body's determinations. The differences between the 1996 guidelines and the revised guidelines are largely ones of tone and of spelling out in greater detail certain sensitive aspects of the guidelines, so it is not immediately obvious why the earlier version of the guidelines was not acceptable and the revised one is. The Recourse Panel even tolerates the express statement in the guidelines that the United States is "aware of no other measure or series of measures ... comparable in effectiveness to the required use of TEDs ${ }^{\prime \prime 69}$ in standard trawl nets, concluding that that statement nevertheless "provides for "inquiry into the appropriateness" of other regulatory programs for different circumstances. ${ }^{170}$

The Recourse Panel, like the Appellate Body before it, was apparently influenced by the overall context and tenor of the State Department's practices. In the first round of the case, the evidence indicated a certain curtness and a rather perfunctory attention to the political sensibilities of foreign governments in the behavior of the State Department. This "ambience" of the Section 609 program seems to have contributed to the Appellate Body's harsh criticism of the "rigid and unbending" U.S. application of the program.17 By 2001, the United States was playing a much more active, supportive role in its work with South Asian governments to get their turtle conservation programs certified. The Recourse Panel takes special note of the United States certification of Pakistan's pro-

\footnotetext{
165 Id. para. 163.

16964 Fed. Reg. 36, 946, 36,950 (July 8, 1999).

170 Recourse Panel Report, supra note 17, para. 5.98.

171 Id.
} 
gram, which combined TEDs use with prohibitions on shrimp trawling in certain areas. ${ }^{172}$ The panel may have been even more influenced to accept the revised United States guidelines by the apparent readiness of the United States to approve Malaysia's program despite Malaysia's obstinacy in declining to apply for certification.173

Even so, the Recourse Panel seemed reluctant to approve the U.S. approach, and quite sympathetic to Malaysia's facial attack on the Section 609 program on the ground that it "violates the sovereign right of Malaysia to determine its own sea turtles protection and conservation policy." 174 This is the second thread of the argument that "coercive" application of Section 609 discriminates "unjustifiably." The Recourse Panel pointedly "recalls" Principle 12 of the Rio Declaration, which states that unilateral actions dealing with environmental problems beyond one's jurisdiction "should be avoided." Nevertheless, "it is the understanding of the Panel" that Shrimp-Turtle holds that a "Member may legitimately require, as a condition of access of certain products to its market, that exporting countries commit themselves to a regulatory programme deemed comparable to its own." 175 The apparent anguish with which the panel reaches this conclusion is a symptom of the WTO's deepseated antagonism to Article $X X$, given that the article itself sanctions resource conservation trade measures taken "in conjunction with" domestic measures affecting the same resource.

The Appellate Body, and the GATT before it, have raised the coercive effect objection to virtually every environmental measure that has come before it.176 Shrimp-Turtle approached this concern under the rubric of "unjustifiable discrimination," a new twist on the old argument, without explaining how a coercive effect constitutes a point of discrimination between countries where the same conditions prevail. From the language in its report, the Appellate Body appears simply to have felt that the overall effect of United States policy, which put pressure on other governments to conform their turtle preservation policies to United States specifi-

172 Id.

173 Id.

174 Id. para. 5.103.

175 Id. para. 5.103.

176 In particular, this was the basis in Tuna-Dolphin II for disallowing the Article $X X$ exception in that case. See supra note 60 and accompanying text. 
cations, was an "unjustifiable" use of trade measures within the WTO system. "M]t is not acceptable, in international trade relations," the Appellate Body opines, "for one WTO Member to use an economic embargo to require other Members to adopt essentially the same comprehensive regulatory program... without taking into consideration different conditions which may occur in the territories of those other Members." 177 The instinct of international adjudicative bodies to react negatively to measures of one nation that truly "coerce" other nations is no doubt healthy, lest power be allowed to override the rule of law.178 But the proclivity of the WTO to act on that instinct to block refuge in the safe haven of Article XX lacks any juridical foundation, and thus itself contravenes the rule of law. Moreover, Shrimp-Turtle grossly exaggerates the nature of the "coercive" power being applied, and thus unreasonably constrains an exercise of power that is explicitly authorized by the GATT.

To begin with, the characterization of environmental trade measures as "coercive" is somewhat hyperbolic. To coerce means "to compel submission or obedience by the use of superior power, intimidation, threats, etc."179 Although in international law scholarship the term "coercive" traditionally embraces the use or threat of economic sanctions, the sanctions so characterized have been more sweeping in effect, and thus more intimidating, than the potential loss of trade in a single product under Section 609 or other environmental trade measures. ${ }^{180}$ Nationals of countries who do not conform their environmental policies to the Section 609 standards can still sell products other than shrimp to the U.S. market, and they can still sell shrimp to other markets. ${ }^{181}$ Although the size

177 AB Report, supra note 9, para. 164.

178 See Abram Chayes \& ANTONIA Handler Chayes, The New SOVERegntY: COMPLIANCE ITITH INTERNATIONAL REGULATORY AGREEMENIS (1995) [hereinafter CHAYES]; $c f$. Parker, supra note 13 (highlighting different theories concerning application of international law as seen through the lens of the Tuna-Dolphin case).

179 WEBSTER's NEw WORLD THESAURUS 317 (3d ed. 1997) (describing synonyms under "force" heading).

180 The usual trade sanctions scenario is the suspension of all trade with a single target country like Cuba or Iraq. See, e.g., GARY CLYDE HUFBAUER,EI AL, ECONOMIC SANCTIONS RECONSIDERED (2d ed. 1990); see also CHAYES, stupra note 178.

181 Indeed, in the Shrimp-Turtle case specifically, three of the four complainants (Pakistan is the exception) exported millions of dollars worth of shrimp to the United States while the WTO case was in process. 
of the U.S. market usually makes the economic cost of foregoing sales to it significant, the sanction of losing shrimp exports worth even hundreds of millions of dollars per year is, the historical evidence clearly shows, insufficient to "coerce" governments to change policies. Malaysia's conduct in the instant case, in which it has devoted more effort to litigating against Section 609 in the WTO than it has to obtaining certification for shrimp exports, is a telling example of the weakness of the coercive effect. The lack of results raises serious questions about the effectiveness of such unilateral economic sanctions, and such sanctions are of course damaging to the general climate for international trade and for cooperative discourse. It is thus quite proper to raise objections to the use of trade measures in general in support of non-trade objectives. ${ }^{182}$ In the interpretation and application of Article XX, however, neither the wisdom of the United States policy nor its effectiveness in reaching U.S. goals should be relevant. The issue for adjudication is whether the chapeau to Article $X X$ forbids the deployment of trade measures to apply pressure on other governments to change their policies.

No language in Article $X X$ or elsewhere in the WTO Agreements warns against, much less forbids, trade measures that put pressure on other governments to change their policies. This is not surprising; many traditional trade measures are designed for just such purposes. Countervailing duties, for example, put pressure on other governments to remove subsidies. SPS measures pressure governments to correct deficiencies in their sanitary regulations. Antidumping duties are often applied to pressure governments to revise economic policies that may be the source of competitive pressures leading to below-cost sales. The only difference between these common practices and environmental trade measures lies not in their coercive effect per se but in the fact that the desired environmental resource policy change lies outside the trade sphere. In

182 E.g., CHAYES, supra note 178, at 88-108 (discussing "unilateral sanctions" and concluding that such sanctions are "not an effective system for the enforcement of any particular treaty" and that a "more cooperative and participatory process is needed."); Howard F. Chang, An Economic Analysis of Trade Measures to Protect the Global Environment, 83 GEO. L.J. 2131 (1995) (arguing that "sticks" not "carrots" should be used to induce nations to participate in multilateral environmental agreements); cf. Parker, supra note 13 (taking issue with Chayes at several points and arguing that unilateral trade restrictions often help promote multilateral cooperation). 
that sense, environmental trade measures are more analogous to trade sanctions against other governments for violation of human rights or for the protection of "national security."

More generally, trade measures do not contradict fundamental international law principles. International law insists upon peaceful modes for the resolution of policy conflicts. When consultations or other diplomatic approaches have failed, governments look to measures that create some degree of hardship for the recalcitrant country, such as suspension or withdrawal of foreign aid. In the same vein, trade measures are often used. Whatever their drawbacks, they are unquestionably preferable to more intrusive or belligerent forms of external pressure. The WTO agreements establish some significant restraints on the use of trade measures in support of national non-trade policy preferences, but they do not foreclose them altogether. Specifically, nothing in Article $X X$ prevents use of the exceptions there granted for non-trade purposes. Quite the contrary, some of the listed exceptions envision such use, including Article XX(a) allowing measures "necessary to protect public morals."

It might be argued that Article $X X(a)$ allows a country to protect its "public morals" against the effects of trade-most likely imported products-that undercut its own moral preferences within its borders, whereas the United States sought to invoke Article $X X(\mathrm{~g})$ to project its environmental preferences onto the domestic policies of other governments. The Appellate Body itself, and the GATT before it in Tuna-Dolphin II, refused to read into Article $X X(\mathrm{~g})$ a geographical limitation on the location of the natural resources that a country might seek to conserve through national restrictions supported by trade measures. With respect to global commons resources such as dolphins and migratory resources such as sea turtles, their effective conservation requires protective action by all, or virtually all, of the nations whose nationals may be acting on those resources. In such contexts, restrictions on domestic production or consumption will be of no avail to conserve the resource in the commons, or even in the country taking the measure, without corresponding protective efforts by other nations. Section 609 was prompted in part by just such a recognition. Indeed, it is hard to imagine any trade measure of the type envisioned by and allowed by Article $X X(\mathrm{~g})$ that would not be written and applied in such a way that the affected countries would have their imports 
into the country taking the measure limited or prohibited unless they adopted national rules that conformed to the resource conservation policies already being applied in the country taking the trade measure.

The deeper problem here may be the oft-remarked difference in the cultures-the modes of thought and understanding-between the trade and environmental communities.183 Shrimp-Turtle, and the other Article XX cases before it, show no understanding of how environmental protection measures operate, and perforce must operate, to achieve their objectives. Broadly speaking, governments can follow one of three instrumental strategies in getting private actors to take steps to protect the environment. They can have voluntary programs (encourage, support, and reward voluntary efforts); they can use economic incentives to induce private actors to take desired measures (including taxes, liability regimes, emissions trading, and the like); or they can use so-called command-and-control regimes (which specify particular behaviors or standards of performance that must be observed, backed by public civil and criminal enforcement). ${ }^{184}$ In practice, national environmental programs in all countries are heavily oriented toward command-and-control, though they have some voluntary and economic incentive elements. Command-and-control systems are relatively inflexible; they leave relatively little choice to the regulated entity (except for the possible strategy of deliberate noncompliance). In that sense, they might be said to be "coercive." Economic incentive measures are more flexible and leave the choice of responsive behavior up to the regulated entity as a participant in a free market where different courses of action have different costs. There is no judicial sanction or moral opprobrium for refusing to adopt the desired behavior, but the individual or firm (or nation) must absorb an economic cost for its failure to cooperate.

Domestically, the United States chose a command-and-control approach to sea turtle conservation, the uniform requirement to

183 E.g., ESTY, supra note 40, at 36-37.

184 For the specific purposes of this very broad and non-rigorous categorization, I would include information collection and disclosure laws, such as the Toxics Release Inventory, under the rubric of economic incentive measures, and procedural and planning requirements such as environmental auditing under the broad heading of enforceable command systems. The environmental policy literature makes much finer distinctions. 
use TEDs. This policy choice was dictated by several factors. First, technical experts had devised a rather simple technological fix to a complicated problem, so a technology-based standard was an obvious choice. Moreover, there were no competing technologies, and the evidence available then, since confirmed by further studies, showed that the TEDs were very effective. Second, the decline in sea turtle populations was severe, so there was an urgent need to implement responsive measures as rapidly as possible. Third, an effective turtle conservation program required near-universal compliance. Voluntary and economic incentive approaches rarely yield either rapid or comprehensive changes in behavior. Fourth, the TEDs requirement was more reliable, much easier to enforce, and interfered less with fishing operations than any alternative for sea turtle protection, such as restricted areas or reduced tow times.

International environmental law regimes also fall into one of the three types, but voluntary and economic incentive approaches are much more common, whereas prescriptive command-andcontrol regimes, lacking the support of domestic-style enforcement mechanisms, are reinforced by collective diplomatic action of treaty parties. Interestingly, several prominent environmental treaty regimes deploy the particular economic incentive of prohibiting treaty parties from trading in the regulated products with nations that are not in compliance with the treaty requirements. ${ }^{183}$ Trade measures have been adopted in these contexts precisely because they are-and are perceived to be-less coercive than other international legal options to influence governments to conform to regimes that depend for their effectiveness on near-universal compliance. This is closely analogous to the situation with respect to sea turtle conservation; the sole, albeit significant, ${ }^{186}$ difference is that the U.S. measures do not stem from a multilateral sea turtle conservation treaty. ${ }^{187}$ Being a unilateral measure, the U.S. shrimp embargo comes out a curious hybrid. It functions as an economic

185 See the three major multilateral agreements: CITES, the Montreal Protocol, and the Basel Convention, supra note 53.

186 Although the WTO has failed so far to express a clear policy that multilaterally-based trade restrictions are permissible under Article $\chi \chi$, the preference for multilateral solutions runs through the Article $X X$ jurisprudence. Sce infri Section 4.2; supra text accompanying notes 52-61.

187 The western hemisphere convention referred to in the AB Report is not in force. See text accompanying notes 199-210 infra for further discussion of that convention. 
incentive - $a$ trade measure-but the standard of behavior it seeks to motivate is defined by a domestic command-and-control program.

The inflexible U.S. policy offends trade experts, but the central legal question of Shrimp-Turtle must be kept in mind: did that inflexibility constitute "unjustifiable discrimination"? The simplistic policy to require TEDs in all countries, though deemed "unjustifiable" by the Appellate Body, looks eminently justifiable when viewed from the environmental policy perspective. It exemplifies the common practice of applying a technological solution uniformly across many countries or regions or actors. To insist, as the Appellate Body does, that environmental policies or technology standards should permit variation according to physical and economic conditions that differ from place to place or firm to firm exalts theoretical elegance over practical responses to political and administrative difficulties in environmental regulation. In an ideal world where all interests operate from a position of perfect information, tailor-made regulations to fit precisely each firm's or each nation's unique situation would clearly be preferable to a one-sizefits all uniform standard across diverse situations. But our information about the state of the environment and the effectiveness of environmental controls is very imperfect, and there is a limit to how many "tailors" the public sector can employ to take the precise measure of each regulation. In the real world, therefore, uniform standards are a staple of environmental regulation. They are relatively simple and transparent, easy for regulators to apply and for the regulated community to understand. And they usually get the basic job done efficiently. Policy makers are not oblivious to the inefficiencies and inequities of uniform "command-andcontrol" regulation. Nevertheless, legal and administrative considerations, including enforceability of rules and simplicity in administration, favor "rigid and unbending" requirements of the kind applied by the United States under Section 609. They continue to be the norm, not the exception, in most fields of environmental regulation. This is as much true of international environmental regulation as it is of domestic regimes. From this perspective, the degree of "coercion" involved in the TED-only 
policy requires a more thorough and thoughtful analysis than appears in Shrimp-Turtle. 188

A deeper problem revealed by the weaknesses in the Appellate Body's handling of this issue is that the WTO simply has no capacity for such analysis. In dealing with a dispute like Shrimp-Turtle, the lack of environmental expertise within the WTO becomes a serious weakness. The missing expertise is not merely one of scientific understanding. That can be remedied by resort to expert consultants; the panel in the Shrimp-Turtle case used, and the Appellate Body benefited from, an international group of experts on sea turtles. What is missing and what hired scientific experts cannot transfer to the WTO, is a deeper, intuitive comprehension of environmental policy that comes only with experience. A group of veteran trade experts dealing only sporadically with environmental cases can never develop a robust capacity to judge these policy issues.

In the final analysis, the Appellate Body simply disagreed with the policy choices the United States made in defining the grounds for "discriminating" between nations whose shrimp imports would be embargoed and nations that would be "certified" under Section 609. Nowhere in Shrimp-Turtle does the Appellate Body state, much less offer a reasoned basis for, the necessary legal conclusion that would give validity to its policy disagreement, namely that the United States policy resulted in "arbitrary or unjustifiable discrimination." With a few exceptions that come up later in the report and will be considered below, 169 the Appellate Body never shows that the United States criteria for discretionary judgments of the United States were applied disparately to countries similarly situated. It never discusses in what respects the United States was unable to "justify" its criteria. The Appellate Body only offers conclusory statements on these essential legal findings. Shrimp-Turtle's central analysis, in short, has no logical structure and lacks a foundation in the text of the chapeau.

188 Ironically, the one effort by the Department of State to make a discriminatory judgment-its early decision to apply Section 609 only in the wider Caribbean/western Atlantic region-was declared legally incorrect as a matter of U.S. law and ultimately resulted in some clear-cut patterns of discrimination in applying the embargo between the western hemisphere countries originally affected and the South Asian countries who broughtSection 609 into dispute in the WTO.

189 See infra Section 4.4.3. 
If Article $X X(\mathrm{~g})$ is to have any application whatsoever, it must necessarily be read to permit trade measures by one country that effectively put pressure on-coerce, if you will-other countries to adopt consistent resource conservation regimes. By disqualifying under the Article $X X$ chapeau any measure that has the result of applying the economic pressure of a trade restriction on other governments unless they change their resource conservation policies, the Appellate Body effectively nullified Article $X X(\mathrm{~g})$.

\subsubsection{Failure to Negotiate a Multilateral Regime as "Unjustifiable Discrimination"}

Shrimp-Turtle opens the other major topic under the rubric "unjustifiable discrimination" with the following assertion:

Another aspect of the application of Section 609 that bears heavily in any appraisal of justifiable or unjustifiable discrimination is the failure of the United States to engage the appellees, as well as other Members exporting shrimp to the United States, in serious across-the-board negotiations with the objective of concluding bilateral or multilateral agreements for the protection and conservation of sea turtles, before enforcing the import prohibition against the shrimp exports of those other Members. ${ }^{190}$

Certainly the very foundations of international law, not to mention a number of specific declarations in recent international environmental law documents (such as Principle 12 of the Rio Declaration), attest to the strong preference of the world community for multilateral consensual solutions to world environmental problems. ${ }^{191}$ Some of these same declarations also assert a negative corollary - that unilateral trade measures to protect environmental resources are to be avoided.192 It takes a large leap of logic, how-

190 AB Report, supra note 9, para. 166.

191 Rio Declaration, supra note 132, Principle 12. It states in part that, "[e]nvironmental measures addressing transboundary or global environmental problems should, as far as possible, be based on international consensus." Id.

192 Id. (declaring in the sentence preceding the one just cited, "Unilateral actions to deal with environmental challenges outside the jurisdiction of the importing country should be avoided."). 
ever, to draw from these general principles the specific legal conclusion that failure to engage other countries in "serious, acrossthe-board" treaty negotiations makes a unilateral trade restriction ipso facto unjustifiable under the GATT Article $X X$ chapeau. There is no inherent connection between unilateralism and discrimination. Establishing international negotiation as a precondition to the invocation of Article $X X$ unreasonably stretches the concept of "justifiability" into sensitive areas of national policy discretion. Multilateralism may be preferable, but it is not obligatory. Moreover, the "serious across-the-board" test sets no definable, predictable standard for determining how much effort at negotiations will satisfy the WTO. The approach to these same issues in the Recourse Panel Report demonstrates the misguided nature of the serious across-the-board negotiations test.

Shrimp-Turtle articulates no historical foundation or legal basis for the conclusion that failure to make bona fide efforts to negotiate a treaty comes within the chapeau's concept of "unjustifiable" discrimination. It simply asserted that the "failure to have prior consistent recourse to diplomacy as an instrument of environmental ... or protection policy ... produces discriminatory impacts on countries exporting shrimp to the United States with which no international agreements are reached or even seriously attempted...."193 In some cases there might be trade discrimination between countries who are members of a treaty regime and others who are not members, ${ }^{194}$ but that is not the case for shrimp trade and turtle conservation. At the time of the Appellate Body report, no international sea turtle conservation treaty regime was in effect.195 The U.S. policy under Section 609 does not purport to make any distinction between countries that have negotiated with the United States and countries that have not negotiated. Even ac-

193 AB Report, supra note 9, para. 167.

194 Such possible discrimination has been one of the main points of discussion in the long-running dialogue in the WTO Committee on Trade and Environment under the topic, "the relationship between the multilateral trade regime and the provisions of multilateral environmental agreements."

195 As discussed below, the Appellate Body places great weight on the negotiation of the Inter-American Convention for the Protection and Conservation of Sea Turtles, supra note 93. This convention did not come into force until May 2 , 2001, and many western hemisphere countries, including many states that harvest shrimp, have yet to ratify it. The convention's significance in the Appellate Body report is therefore symbolic, not legal. Id. 
cepting the Appellate Body's assertion that the United States made no bona fide efforts to negotiate a treaty with the Asian complainants while it seriously pursued negotiations with western hemisphere countries, absolutely no discrimination in trade resulted from such differences in foreign policy. In the absence of discrimination, the Appellate Body cannot logically find "unjustifiable" discrimination.

Indeed, to qualify potentially under Article XX, Section 609 could not make distinctions between countries based on their willingness to negotiate or their participation in an international regime. If the embargo provisions of Section 609(b) had in some way been linked with the responsiveness of countries to negotiations pursued under Section 609(a) regardless of their actual turtle conservation practices, that would have created fair grounds to argue that the policy discriminated unjustifiably between countries where the same conditions prevail. Moreover, a trade measure linked to a country's willingness to negotiate would be "coercive" (in the Appellate Body's usage) with respect to an arena of national sovereignty -its foreign relations-distinctly more sensitive than its resource conservation policies. Formal participation in a treaty, much less willingness to negotiate toward a treaty, has no bearing on an objective assessment of a nation's resource conservation practices and thus may not constitute a basis for discrimination in trade.

As before with respect to coercive effect, Shrimp-Turtle's approach to multilateralism confuses policy and law. The Appellate Body refers to the Rio Declaration language on avoidance of unilateral action and to international environmental conventions that affirm an international preference for "concerted action" on protection of endangered species. ${ }^{196}$ As a matter of policy, no government takes exception to the importance of international cooperation in addressing environmental problems of international scope, especially species protection. The question for the Appellate Body, though, is narrower and more analytic-to interpret the law of the WTO agreements. ${ }^{197}$ The Appellate Body may properly take

196 AB Report, supra note 9, para. 168.

197 Indeed, the function of the Appellate Body is narrower than that of dispute settlement panels. Appeals to the Appellate Body are "limited to issues of law covered in the panel report and legal interpretations developed by the pancl." GATT, supra note 4, art. 17.6. "The Appellate Body may uphold, modify or re- 
into account the policy preferences of the members, but its role is to develop legally sound and generally applicable interpretations of the agreements. Notwithstanding the nearly unanimous sentiment in the WTO membership against unilateral trade measures for environmental purposes, the text of Article $\chi \chi$ makes no explicit reference to unilateral or multilateral action.

Nor does the language of Article $X X$ offer any basis from which to infer that multilateral action is a chapeau precondition for national measures. The legal question is the meaning of the term "unjustifiable discrimination." The origins of Article $\chi \chi$ and the close analogy with the SPS Agreement lead to the conclusion that "unjustifiable" discrimination means only discrimination in trate between two countries similarly situated for which the country taking the measure can provide no reasoned explanation related to the policy behind the measure.198 Such discrimination might occur in the context of multilateral agreements as well as in cases of unilateral action ${ }^{199}$ the simple distinction between multilateral strategies and unilateral strategies by itself has no bearing on the presence or absence of trade discrimination.

By its very nature, Article $X X$ allows independent national action in certain policy fields, subject only to the chapeau conditions. Nothing in the lettered paragraphs or the chapeau constrains a member government's choice among multilateral, regional, bilateral, or unilateral approaches. Yet from the policy miasma that has

verse the legal findings and conclusions of the panel." Id. art. 17.13. Dunoff, infra note 274 , makes the excellent point that too strictly legal an approach by dispute settlement panels in "trade and" cases puts them in the quandary of trying to draw "principled lines in the midst of larger political struggles." Id. at 755. But Dunoff's apprehension about these dangers, and his prescription for a deliberate strategy of avoidance, depends on his premise that a strict reading of GATT will be inimical to the social objectives of the "and" interests. Id. at 757. The premise of the present Article is quite the opposite: at least with respect to Article $X X$, a more rigorous legal analysis of the GATT text would actually favor environmental values.

198 See discussion supra Section 4.2.1. for the full argument about the proper meaning of "unjustifiable discrimination."

199 The years of debate in the WTO Committee on Trade and Environment about the GATT-compatibility of trade measures in multilateral environmental agreements ("MEAs") have focused precisely on the potential for "unjustifiable" discrimination in those regimes. The most common hypothetical given is trade discrimination based exclusively on whether a trading partner is or is not a party to the MEA, without regard to its conformity with the environmental requirements of the MEA. 
surrounded Article $X X$ since Tuna-Dolphin I ten years ago, the Shrimp-Turtle report draws an obligation for WTO members to pursue multilateral approaches before they can exercise their Article XX rights. As the recent Shrimp-Turtle Recourse Panel states, "the Appellate Body, like the Original Panel, considered that negotiations should have taken place before an import prohibition was applied." 200 In construing the contours of this obligation, the panel stops just short of a complete nullification of Article XX:

[1]t seems appropriate for us first to determine the actual scope of the ... findings, as adopted by the DSB, in respect of the negotiation of an international agreement before reviewing the modifications made by the United States to its original measure. Indeed, if we were to conclude that the United States may not impose any measure of the type currently applied except pursuant to an international agreement, it would not be necessary to review any further the compatibility of the implementing measure ....201

It seems inconceivable that a WTO panel would even countenance the idea that Article $X X$ allows national measures only pursuant to international agreements, when nothing at all in the text of the article suggests such a stringent limitation. That, however, is where Shrimp-Turtle has situated the analysis. A closer examination of the Recourse Report reveals the extent of the interpretational hazards that stem from forging a link between multilateralism and trade discrimination that has no foundation in the Article XX text.

The Recourse Panel purported to find "clear guidance" about the nature and extent of the obligation to engage in multilateral negotiations in the Appellate Body's broad notion that the chapeau protects against the abuse or misuse of the rights granted by Article XX.202 From the notion of abuse of rights the panel develops an argument that there is a fact-dependent, shifting "line of equilibrium" between unilateral measures and multilateral approaches to

200 Recourse Panel Report, supra note 17, para. 5.30 (emphasis in original).

201 Id. fra.

202 For a discussion of these broader contextual arguments see Section 4.3. in- 
environmental problems. ${ }^{203}$ In the Shrimp-Turtle context, it concludes that the migratory nature and worldwide distribution of sea turtles "significantly moves the line of equilibrium ... towards a bilaterally or multilaterally negotiated solution, thus rendering recourse to unilateral measures less acceptable."201 In a remarkable extension of logic, it then articulates the legal standard to be applied as one of "whether the line of equilibrium in the field of sea turtle conservation and protection is such as to require the conclusion of an international agreement or only efforts to negotiate." 225 The panel here not only countenances, but embraces, a remarkable interpretation of Article $X X$ that would deny all right to national measures outside the context of an international agreement in some circumstances. Fortunately, the panel then retreats from that extreme position, finding that the Appellate Body "considered that the requirement is one of "negotiation," not "conclusion" of an agreement," and that "recourse to a unilateral measure cannot $a$ priori be excluded under Article XX of the GATT 1994."20s

This jurisprudence of compulsory multilateralism is especially unfortunate because it hobbles the very multilateral negotiations it purports to promote. It is one thing to hold a general preference for multilateral action to address transboundary or global environmental problems; such a preference has nearly universal acceptance. It is highly problematic, however, to legally "coerce" a multilateral approach to every issue by insisting that a country "had to engage in negotiations" 207 before it employs other strategies. A rich literature in law and political science explores the intricate, multidimensional, and inherently unpredictable process of developing international agreements in general and international environmental agreements in particular. ${ }^{208}$ With respect to Article $X X$ interpretation, this scholarship demonstrates a complex interplay between national action and national politics on the one hand and the exercise of and response to international diplomacy on the other. Even when international agreement is the ultimate goal,

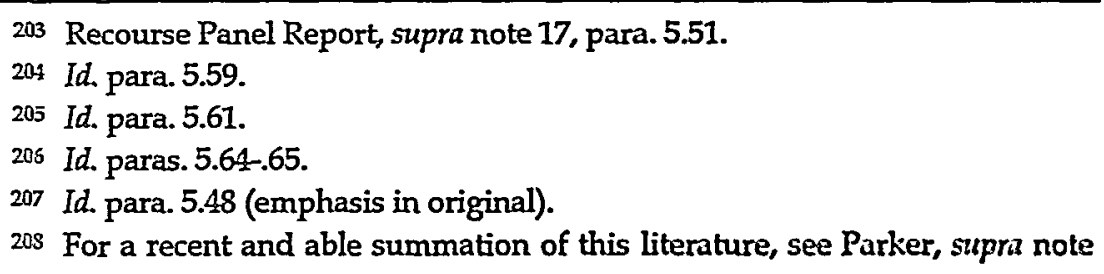
13. 
unilateral national action may be necessary or appropriate to create a suitable context for formation of the desired regime. As Professor Parker summarizes:

[T]una-Dolphin is not unique. It is simply another installment in a line of cases that establish the more-thanoccasional need for unilateral action, including trade leverage. These are the "hard cases" of cooperation. In such cases the truth is plain: to deny a regime the benefits of unilateral action is to deny it the prospect of change. ${ }^{209}$

The Article $X X$ chapeau should not be interpreted "to deny ... the prospect of change" in the faltering international effort to preserve the world's remnant populations of sea turtles.

Shrimp-Turtle also makes an issue of the fact that the statutory language of Section 609 mandates international negotiations and that the Department of State largely failed "to carry out the express directions of Congress." 210 While the State Department is open to that charge, a failure by the Executive Branch to "faithfully execute" a clear congressional mandate, while an important matter in U.S. domestic law, 211 has no direct bearing on the legality of U.S. trade behavior vis-à-vis other nations. ${ }^{212}$ The only matters of

209 Id. at 107.

210 AB Report, supra note 9, para. 167.

211 The decisions of the Court of International Trade in the Shrimp-Turtle case are grounded in matters of administrative failure to follow statutory instructions. See, e.g., Earth Island Inst. v. Christopher, 922 F. Supp. 616 (Ct. Int'1 Trade 1996) (rejecting the State Department's request for more time to comply with the court's earlier order). Of course, separation of powers principles and the Constitution's grant to the executive branch to conduct the foreign affairs of the nation make it doubtful whether a court would attempt to enjoin executive branch compliance with a congressional directive to engage foreign governments in negotiations. $C f$. Japan Whaling Ass'n v. American Cetacean Society, 78 U.S. 221 (1986) (holding that a statutorily indicated and arguably nondiscretionary decision to "certify" Japan for possible trade sanctions based on clear facts that Japan was undermining the International Whaling Convention was nevertheless discretionary given its close relationship to the executive's prerogative to manage foreign policy).

212 To its credit, the Recourse Panel acknowledges that execution or nonexecution of Section 609 (a) "as such is not a ground for a finding of unjustifiable discrimination unless, in implementing Section 609(a), the United States authorities have discriminated between exporting countries by negotiating seriously with some and less seriously or not at all with others." Recourse Panel Report, supra note 17, para. 5.44 . 
proper concern to the WTO are the trade effects of the actual policy of the United States government as a whole, regardless of which branch of government had final responsibility for it. Such argumentation by the Appellate Body takes it further and further from the core legal issues to be adjudicated.

Even accepting for the purposes of argument that a WTO member should be required to make an effort toward an international solution before resorting to unilateral self-help, the Appellate Body's insistence on prior "consistent" recourse to "serious across-the-board" negotiations establishes an undefinable and unpredictable threshold for "access" to Article XX. Under this test, no government can ever be sure that its initiatives toward a multilateral agreement, in advance of a unilateral trade measure, will be sufficient to satisfy trade-dispute adjudicators. This difficulty becomes clear in the further exposition of the Recourse Panel as it sought to "assess the extent of the efforts required"213 by the Shrimp-Turtle holdings. If the obligation is presumed to exist, one cannot quarrel with the further stipulation that it is an obligation "to make serious good faith efforts to reach an agreement," that the "negotiations had to be with all interested parties ('across-theboard')," and that there must be a "continuous process" rather than a "one-off" exercise.214 The Recourse Panel, however, ventured far beyond the criteria for measuring the extent of the effort in space and time to insinuate criteria for the tenor and content of such negotiations.

Because the Appellate Body had referred to the Inter-American Convention as a demonstration of the feasibility of consensusbased approaches, the Recourse Panel concluded:

that the Inter-American Convention can reasonably be considered as a benchmark of what can be achieved through multilateral negotiations in the field of protection and conservation. While we agree that factual circumstances may influence the duration of the process or the end result, we consider that any effort alleged to be a 'serious good faith

213 Id. para. 5.48.

214 Id. paras. 5.66-.67. 
effort' must be assessed against the efforts made in relation to the conclusion of the Inter-American Convention. 215

For the WTO to set up the level of effort at a particular regional negotiation as a legal standard for judging the "good faith" of contemporaneous or subsequent efforts at negotiations in another region or on a global level is a breathtaking exercise of legal and policy hubris, all the more remarkable because it judges the conduct of WTO members in an area of policy in which the WTO has repeatedly disavowed any expertise. Yet the panel goes even further. Taking as its premise the Appellate Body's dictate that the United States policy needed to allow consideration of any differences in Shrimp-Turtle situations in other countries, the Recourse Panel determined that the efforts at multilateral negotiations must likewise be structured so as to take into account "the situations prevailing in the other negotiating countries." 216 It further suggests that it would therefore be inappropriate to use the pressure of Section 609 to influence the negotiations by constraining negotiators "to accept conditions that they may not have accepted had Section 609 not been applied. Even if Section 609 as currently applied takes more into account the existence of different conservation programmes, it can still influence the outcome of the negotiations." On this ground, the panel declares it to be:

important to take the reality of international relations into account and considers that the standard of review of the efforts of the United States on the international plane should be expressed as follows: whether the United States made serious good faith efforts to negotiate an international agreement, taking into account the situations of the other negotiating countries. ${ }^{217}$

In the name of protecting WTO members against an "abuse" of the Article $X X$ rights of another member, then, the WTO is setting

215 Id. para. 5.71.

216 Id. para. 5.73.

217 Id. 
itself up as the arbiter of the faimess of environmental negotiations.

German sociologist Juergen Habermas has advocated an ideal pattern of democratic discourse in which the participants in a policy negotiation are entirely free of any social or economic constraint so that consensus is reached through purely rational argument and objective consideration of differing viewpoints.218 His model has much to recommend it, but he advances it as a critique of current legal systems, not as a description of what domestic law, much less international law, requires. Habermas would certainly be surprised that the WTO has adopted constraint-free international negotiation as an operative legal precondition for use of trade measures to protect the environment. Too sensitive, perhaps, to the power-based "reality of international relations," the Recourse Panel has abstracted and idealized how multilateral negotiations should operate. The panel also seems oblivious to the internal contradiction of its argument-namely, that it is using the Inter-American Convention, negotiated precisely among those countries subject since 1991 to the rigors of the Section 609 policy, as a benchmark for a negotiating process in which the influence of Section 609 is to be suppressed.219 It is hard to imagine that any

218 John Dryzek describes the Habermasian ideal as follows:

Communicative rationality clearly obtains to the degree social interaction is free from domination (the exercise of power), strategizing by the actors involved, and (self-) deception. Further, all actors should be equally and fully capable of making and questioning arguments (communicatively competent). There should be no restrictions on the participation of these competent actors. Under such conditions, the only remaining authority is that of a good argument, which can be advanced on behalf of the veracity of empirical description, explanation, and understanding and, equally important, the validity of normative judgments.

John S. Dryzek, Discursive Democracy: Politics, Policy, and Political Science 15 (1990). Dryzek's description draws on two works by Juergen Habermas. See Juergen Habermas, The Theory of Communicative Action I: Reason and the Rationalization of Society (1984); Juergen Habermas, The Theory of Communicative Action II: Lifeworld and System (1987).

219 This same contradiction also appears in the apparent difference between the panel and the United States in drawing lessons from the Inter-American Convention. The panel expresses an opinion that the convention regime is "quite demanding." and supposes that future negotiations may yield equally demanding regimes. The United States apparently expressed a contrary view. The United States may have appreciated that the "demanding" nature of the Inter-American Convention reflects the fact that all the negotiating parties had already imple- 
person who drafted or negotiated over Article $X X$ in the 1940 s could have imagined such a condition on its use.

The Recourse Panel imposes yet one more remarkable condition on good faith negotiating efforts that further erodes the residual scope of Article $X X$ : it asserts that the obligation to negotiate toward a multilateral agreement, at least in the sea turtle context, is a continuing obligation, so that the opportunity of the United States to apply Section 609 under the protective shield of Article $X X$ is "more to be seen as" a "provisional" (the panel's emphasis) authority "allowed for emergency reasons than as a definitive "right" to take a permanent measure. The extent to which serious good faith efforts continue to be made may be reassessed at any time."220 Not only that, this "provisional" authority "may only be accepted under Article XX ... if [the measures] were taken further to the completion of serious good faith efforts to reach a multilateral agreement...."221

The end result of the Recourse Panel's gloss on the Appellate Body's condition that unilateral measures under Article XX can only be taken after serious efforts at multilateral negotiations is to reduce Article $X X$ to an emergency measure (with the nature of the qualifying "emergency" left undefined) that can be applied only in direct connection with ceaseless efforts to reach a multilateral agreement. This turns Article $X X$ on its head. The text of Article $X X$ allows, and should be construed by the WTO to allow, a country to take measures, presumably of long duration, to conserve exhaustible (not exhausted) natural resources so long as those measures are in conjunction with comparable domestic measures to conserve the same resource. Under this plain vanilla reading of Article XX, WTO members are allowed, within the constraints of the chapeau, to employ market access restrictions on certain resource-related products that will act as a constant stimulus toward an effective multilateral regime that would then take the place of

mented TEDs requirements, while the negotiating dynamics with the Asian countries are significantly different and less likely to yield a turtle conservation program of equivalent stringency. Recourse Panel Report, supra note 17, para. 5.75. The panel subsequently remarks on the "capacity of persuasion" of the United States, id. para. 5.76, without appreciating that to take Section 609 out of the negotiating context substantially reduces that persuasive capacity.

220 Id. paras. $5.86,5.88$.

221 Id. para. 5.88 . 
the unilateral measure. It is up to the country or countries subject to the trade restriction to initiate negotiations or be responsive to negotiating opportunities so as to have the trade restrictions lifted. International environmental history confirms the usefulness of such economic motivations in prompting countries to protect resources of regional or global significance.

Given the endless variations in international affairs, the Appellate Body should not have interpreted the chapeau so that the WTO sits in judgment of the wisdom of a member's particular foreign policy strategy or outcome. Experience with past international negotiations supports the U.S. decision in the shrimp-turtle context to negotiate first with countries having closely-shared concerns before attempting a world-wide treaty among more diverse nations.222 Moreover, ten years of deliberations in the GATT and the WTO about the relationship between Article $X X$ and multilateral environmental agreements reveal unanimity on one key point imposition of trade restrictions to promote compliance or to punish noncompliance with a multilateral regime should not depend on the formal status of the offending country as a party or non-party to the treaty, but on whether the offending country had or had not put into effect the national legal structure for enforcing the rules of the multilateral regime. National behavior as it actually affects the environment, then, is the key differentiating factor for trade restrictions, regardless of nominal participation in a particular treaty arrangement.

The Appellate Body's discussion of the multilateralism issue also reveals an other-worldly naivete one would not expect from senior trade diplomats. The Appellate Body argued that the ability of the United States to reach agreement with its western hemisphere neighbors on a convention text that includes language recognizing certain GATT obligations demonstrated "that consensual and multilateral procedures are available and feasible for the establishment of programs for the conservation of sea turtles."203 Even casual observers of international affairs understand that an

222 See generally PETER M. HAAS, ROBERT O. KFOHANE, \& MAKC A. LEV,, INSTITUTIONS FOR THE EARTH: SOURCES OF EFFECTIVE INTERNATIONAL ENVIRONMENTAL PROTECTION (Global ENVIRONMENTal ACCORDS) (1993) (using case studies to explore the development of values of concern and a contractual environment, two predicates to negotiating effective environmental agreements).

223 AB Report, supra note 9, para. 170. 
agreement among one group of countries does not signal the readiness of other countries to accept a comparable agreement. The South Asian complainants could have proposed international negotiation themselves or signaled their willingness to accept the same obligations as those in the Inter-American Convention. The historical record indicates quite the contrary reaction, a rejection of the United States overtures and a resistance to adoption of the available TED technology in their shrimp fisheries. At the time of its decision, the Appellate Body was indulging in wishful thinking, not clear-headed analysis, when it claimed that "[t]he InterAmerican Convention thus provides convincing demonstration that an alternative course of action was reasonably open to the United States for securing the legitimate policy goal of its measure, a course of action other than the unilateral and non-consensual procedures of the import prohibition under Section 609."224 Even as of late 2001 there is no agreement, and no imminent prospect of agreement, outside the Western Hemisphere. The Appellate Body also ignored the pertinent fact that the negotiation of the InterAmerican Convention came about after the threat of a shrimp embargo under Section 609 and compliance by all countries in the wider Caribbean/western Atlantic with the "rigid and unbending" United States insistence on comprehensive use of TEDs by shrimp trawlers. Dispassionate analysis of this record gives greater support to the opposite conclusion from the one drawn by the Appellate Body: the signatures of western hemisphere governments to the Inter-American Convention showed the effectiveness of the "unilateral and non-consensual procedures of ... Section 609" in changing policy preferences in the targeted countries and fostering the political climate for a successful international negotiation.

224 AB Report, supra note 9, para. 171. In a further, gratuitous criticism of the United States in footnote 174 for its non-accession to certain international environmental agreements, including the U.N. Convention on the Law of the Sea and the Convention on Biological Diversity, the Appellate Body comes close to questioning whether the U.S. interest in sea turtle preservation is bona fide. I draw a much different inference from the same facts: they provide strong evidence of the difficulty of getting various countries to agree to international environmental protection agreements even when those countries acknowledge the underlying environmental problems. The U.S. failure to sign the U.N. Convention on the Law of the Sea and the U.S. failure to ratify the Convention on Biological Diversity have mostly to do with the way those agreements impinge on certain commercial interests and with the associated political (and partisan) preoccupation with yielding control to international authorities. 
When it finally focused in the issue of discrimination in trade, the Appellate Body completely misconstrued the operation and effects of the United States policy. It characterized the policy of the United States to negotiate "seriously with some, but not with other Members (including the appellees)" as "plainly discriminatory" in its effect. This claim does not withstand even casual scrutiny. The western hemisphere countries were subjected to the pressures of Section 609 years before the law was applied to the Asian appellees. The Caribbean/Atlantic deadline for compliance with the TEDs requirement came more than two years before the conclusion of the Inter-American Convention. Besides, the Convention was not in force at the time of the Shrimp-Turtle report, so it was inappropriate for the Appellate Body to ascribe any legal significance to its negotiation. At that point, it symbolized little more than a shared political commitment. Building on its mistaken proposition about the "plainly discriminatory" effect of United States diplomacy, the Appellate Body proceeded to argue, "The unjustifiable nature of this discrimination emerges clearly when we consider the cumulative effects of the failure to pursue negotiations .... . The principal consequence of this failure may be seen in the resulting unilateralism evident in the application of Section 609."225 On the contrary, the implementation of the embargo provisions of Section 609 (b) is completely unaffected by any progress, or lack of progress, toward international agreement under Section 609(a). The implementation of the United States embargo depends principally on TEDs requirements in the national laws of shrimp-exporting countries and the actual use of TEDs, without regard to participation in any related international agreement. To negotiate with the western hemisphere countries first was therefore not discriminatory in any GATT-relevant sense, since those negotiations had no effect on trade embargo decisions under Section 609. Moreover, the Appellate Body's argument depends on the implicit assumption that the Asian appellees would have followed a different course of conduct with respect to sea turtle protection if the United States had "negotiated seriously" with them, and that the unilater-

225 AB Report, supra note 9, para. 172 (emphasis added). 
alism of Section 609 (b) could have thereby been avoided. Nothing in the record then or since makes that assumption credible.226

In the final analysis, the Appellate Body's argument on unilateralism and multilateralism in its original Shrimp-Turtle report becomes tautological. "The unilateral character of the application of Section 609 heightens the disruptive and discriminatory influence of the import prohibition and underscores its unjustifiability."227 The only unjustifiably discriminatory effect of United States policy that the Appellate Body perceives is its unilateralism. In the Appellate Body's logic, then, the "unilateral character" of Section 609 heightens and underscores the unjustifiably discriminatory effect of the "resulting unilateralism" of applying Section 609. The tautology is complete. The unilateral nature of the United States measures seems to be what really offends the WTO, not any resulting "discrimination." Yet, if Article XX has any purpose at all, it is precisely to permit WTO members to take unilateral trade measures that contravene other GATT principles. To argue that the chapeau condition barring "unjustifiable discrimination" precludes unilateralism is to eviscerate Article $X X$.

The Recourse Panel Report puts the WTO in has adopted the unfortunate position that Article XX measures can only be used as a last resort or as occasional prods on recalcitrant countries who remain at liberty, without fear of serious economic loss, to despoil or endanger a natural resource of international significance. Countries promoting resource conservation and sustainable development are reduced to the role of perpetual suitors for the good graces of countries not yet contributing to an international conservation program. And it apparently matters not at all to the WTO that critically endangered species, like some species of sea turtles, may become extinct in the meantime, a loss to humanity as profound, if not more profound, than the loss of pieces of our world heritage like the Buddha statues of Bamiyan.

In its report reviewing the Recourse Panel report, the Appellate Body does not specifically comment on, much less disavow, the panel's extreme interpretation of the "requirement" for prior effort

226 United States, First Submission Brief to the WTO Dispute Settlement Panel, June 9, 1997, para. 32 (noting that three complaining governments "declined to accept the offer [in late 1996] of multilateral negotiations" toward a protocol or agreement for the Asian region).

227 AB Report, supra note 9, para. 172 (emphasis added). 
at multilateral solutions before invoking Article $\chi \chi$ rights. Nevertheless, in affirming the panel's ultimate holding that the U.S. practices since 1998 satisfy the chapeau conditions, the Appellate Body shifts the emphasis away from "prior" recourse to a more mundane concern with the perceived discrimination in treatment between the Western Hemisphere nations and the Asian nations in United States diplomacy. The Appellate Body highlights its earlier finding that the United States had "negotiated seriously with some, but not with other Members," 228 and articulates its test in new language as one that a Member "would be expected to make good faith efforts to reach international agreements that are comparable from one forum of negotiation to the other." 229 The Appellate Body immediately clarifies that "[ $t]$ he negotiations need not be identical .... Yet the negotiations must be contparable in the sense that comparable efforts are made, comparable resources are invested, and comparable energies are devoted to securing an international agreement." 230 Referring back to its discussion in the main report of the Inter-American Convention, the Appellate Body further clarifies that that convention should be used only as an "example" for such a comparability analysis, and not as a substantive standard or "benchmark."231

While this new gloss on Shrimp-Turtle is helpful in understanding the criteria for establishing discrimination when comparing different negotiating contexts, it still leaves open the problematic issue noted above 232 about the threshold of efforts, resources, and energies needed to satisfy the implicit more general requirement, which the Appellate Body's recourse report does not question, that there must always be a good faith effort at negotiations before invoking Article $X X$ rights. On that question, the only point that the Appellate Body makes absolutely clear is that the obligation is one to negotiate, not to reach agreement.

228 AB Recourse Report, supra note 23, para. 121 (quoting AB Report, stupra note 9, para. 172).

229 AB Recourse Report, supra note 23, para. 122.

230 Id.

231 Id. para. 130.

232 See supra text accompanying notes 197-203. 
[I]t is one thing to prefer a multilateral approach in the application of a measure that is provisionally justified under one of the subparagraphs of Article XX of the GATT 1994; it is another to require the conclusion of a multilateral agreement as a condition of avoiding 'arbitrary or unjustifiable discrimination' under the chapeau of Article XX. We see, in this case, no such requirement. ${ }^{233}$

That last qualifier, "in this case," leaves one with the uneasy feeling that the preference for multilateralism remains so strong that unilateral measures affecting transnational or global resources outside the context of any systematic effort to promote a multilateral solution will, ipso facto, not qualify under Article XX. A1though it never so holds explicitly, the Appellate Body's language suggests that it would not have found Section 609 qualified if it had not contained the Section 609(a) congressional instruction for the pursuit of international negotiations. The carrot of Section 609(a) was a desirable expression of policy, but nothing in the GATT suggests that it should be a necessary precondition to invoking the shelter of Article $X X$ for the embargo stick of Section 609(b).

\subsubsection{Differential Application of Section 609 to the Asian Complainants as Arbitrary}

We come at last to certain elements of Shrimp-Turtle where narrower and more legitimate questions arise about "unjustifiable" or "arbitrary" discrimination in the implementation of Section 609. As noted at the beginning of this Article, there were deficiencies in the administration of Section 609 that resulted in arbitrarily or unjustifiably discriminatory treatment of the Asian complainants visà-vis western hemisphere members. The Appellate Body takes up these points in a by-the-way fashion in just a few paragraphs at the end of its report commenting on "other differential treatment." 234 The ultimate holding that the United States practices resulted in "arbitrary or unjustifiable discrimination" is on much firmer ground with respect to these minor points. Even in this context,

233 AB Recourse Report, supra note 23, para. 124.

234 Id. para. 173. 
though, Shrimp-Turtle makes some claims about the discriminatory effects of United States implementation that cannot withstand close scrutiny.

The root of the problems in the administration of Section 609 lies in the 1991 determination by the Department of State to apply the statute to only one region - the "wider Caribbean/western Atlantic" - despite the absence of any geographical limitation in the statutory language. By the time environmental organizations had challenged this geographic restriction in court and the Court of International Trade ("CIT") rendered its decision that the statute applied worldwide, the statutory deadline for the imposition of the shrimp embargo had long since passed. Rejecting the request of the United States government for extra time, the CIT insisted that the application of Section 609 to countries outside the wider Caribbean/western Atlantic be made effective within five months of its decision. 233

Two distinct elements of discriminatory treatment of the newly-affected Asian countries arose from this history. Most obviously, the complaining WTO members were given just months to satisfy the requirements to avoid an embargo, whereas the countries of the wider Caribbean/western Atlantic had been given three years to achieve full compliance. This discrimination had no "justification" other than the politically ill-advised order of a federal court. One could argue (and the United States did) that the Asian complainants had more rather than less time to comply because the deadline for them was nearly two years later than the deadline for the Caribbean countries, but that ignores the 1991 determination by the Department of State that the Asian complainants were outside the scope of Section 609 and therefore did not need to implement TEDs to continue their shrimp exports to the United States.235 Once an enforceable compliance deadline was established, the Asian countries faced a formidable task to avoid the shrimp embargo. The Appellate Body had ample reason to conclude that the short time-frame for compliance imposed "administrative and fi-

235 Earth Island Inst. v. Christopher, 922 F. Supp. 616 (Ct. Int'l Trade 1996).

236 The United States also argued that the three-year phase in of TEDs regulations for the wider Caribbean countries was needed because the TEDs technology was still under development, but that by 1996 the implementation of a TEDs requirement in the Asian countries could have been accomplished in much less time. See AB Report, supra note 9, para. 174. 
nancial costs" and presented "difficulties ... in putting together and enacting the necessary regulatory programs." 237

A second element of discrimination also arose out of the shortened time frame for compliance. The United States was not ready or able to offer the Asian countries the same level of organized technical and legal assistance on TEDs and their regulation that it had provided to the wider Caribbean countries.238 The United States did hold some workshops in Asia on turtle conservation and TEDs, including several workshops in each of the complaining countries except Pakistan,239 but it did not conduct the kind of intense technical assistance campaign there that it had with the wider Caribbean countries. Thus, the stick of the shrimp import embargo for the Asians was not accompanied by the carrot of effective assistance.

These differences in application are certainly understandable in light of the initial decision by the State Department to limit Section 609 to the wider Caribbean region, the subsequent invalidation of that approach by the Court of International Trade, and the court's tight timetable for compliance with its order. The differences may also be attributable in part to a foreign policy choice by the United States to give closer attention and greater support to its near neighbors in the Caribbean, and less attention and support to the south and southeast Asian countries.240 But no matter how understandable the explanations, the differences in application of Section 609 created an apparent pattern of discrimination among trading partners. For trade purposes, it matters only whether there was discrimination between countries similarly situated, and whether that discrimination was arbitrary or unjustifiable in trade terms. The United States did not discriminate in trade against Thailand, which was certified under Section 609 , but to the extent that the

237 Id.

238 AB Report, supra note 9, para. 175.

239 United States, First Submission, supra note 92, paras. 34-36.

240 Another explanation for the discrepancy in diplomatic treatment is a strategic choice about the most effective negotiating strategy to adopt in pursuit of a long-term goal of a broadly multilateral agreement. In political science terms, this is a judgment about creating the right context for regime formation. Such a strategic choice would really amount to a decision about effective environmental policy, and should therefore be granted deference in a trade-based dispute settlement proceeding. For further elaboration of this argument, see supra text accompanying notes 204-10. 
embargo against wild-caught shrimp from the other three complainants was an outgrowth of the peculiar and unbalanced implementation of the TEDs program by the United States government, exacerbated by the rulings of a United States court, rather than because of differences in their own practices relevant to turtle protection, such discrimination would be arbitrary or unjustifiable in the WTO context.

Another point of alleged discrimination against the Asian complainants relates to the general procedures followed by the United States government in rendering decisions on certification of national sea turtle protection programs. Certification of the national program under Section 609 is a general precondition of access to the United States market for shrimp and shrimp products. The Appellate Body, applying at this point the concept of "arbitrary" discrimination, finds that the certification procedure is neither transparent nor predictable. In particular, the Appellate Body singles out three aspects of the procedure that offend its sense of "fairness and due process." 241 First, the Office of Marine Conservation in the Department of State, the ultimate decision-making agency, consults ex parte with officials in the United States National Marine Fisheries Service in the Department of Commerce in evaluating a certification application. The applicant country has no formal opportunity to be heard or to respond to any arguments raised within the United States government against its application. Second, "no formal written, reasoned decision, whether of acceptance or rejection, is rendered" 242 on applications for certification. Third, according to what the United States apparently represented during the oral hearing before the Appellate Body, "[n]o procedure for review of, or appeal from, a denial of an application is provided." 243 Given the "singularly informal and casual" procedures of the United States, the Appellate Body concludes: "It appears to us that, effectively, exporting Members applying for certification whose applications are rejected are denied basic fairness and due process, and are discriminated against, vis-à-vis those Members which are granted certification."244 183.

241 The points that follow are raised in AB Report, supra note 9, paras. 180,

242 AB Report, supra note 9, para. 180.

243 Id.

244 Id. para. 181. 
However legitimate the criticism of the "informal and casual" procedures for making Section 609 certification decisions, ShrimpTurtle's blanket conclusion that those who are denied certification have been "discriminated against" is a complete non sequitur. Those who received certification were, after all, subject to the same non-transparent process as the others. There is no claim of discrimination in the procedures followed or decision criteria applied; the only difference is the result. Without some evidence that the United States officials were engaged in dishonest or manipulative behavior, it would be more reasonable to assume is that the countries were denied certification because their programs did not meet the rather straightforward and duly promulgated and published criteria for certification. That would not be an arbitrary discrimination in procedure but a legitimate "discrimination" on the merits based on a determination that the "same conditions" prevailing in certified countries did not prevail in the uncertified countries. Because the chapeau of Article $X X$ involves an assessment of whether the application of the measure "results in" abusive discrimination, it was incumbent upon the Appellate Body to establish that there was discrimination in practice, not merely the procedural possibility of surreptitious and unexplained discrimination.

To bolster its argument on this point, the Appellate Body refers to Article X:3 of the GATT. ${ }^{245}$ The first paragraph of Article $X$ sets forth an obligation to publish trade-relevant "laws, regulations, judicial decisions and administrative rulings of general application."246 There is no question that the Department of State's regulations on the implementation of Section 609 are rules of general application, and that they were duly published in the Federal Register. Paragraph 3(a) then charges each WTO member to "administer in a uniform, impartial and reasonable manner" all such rules of general application. The Appellate Body does not find that the administration of the Section 609 rules was other than "uniform"

245 One question, of course, is whether the application of a measure that otherwise qualifies for an exception under Article $X X$ must nevertheless be in conformity with Article $X$. The Appellate Body argues that, "it is only reasonable that rigorous compliance with the fundamental requirements of due process should be required in the application and administration of a measure which purports to be an exception to the treaty obligations of the Member imposing the measure ...." AB Report, supra note 9, para. 182. That argument has some appeal, and will be accepted as valid for the purposes of the current analysis. Id.

246 GATT art. X, para. 1. 
and "impartial." On the contrary, the Appellate Body made a major point of the unjustifiably "rigid and unbending" uniformity of the United States policy, which required every country to implement a comprehensive requirement for TEDs. So the Appellate Body is apparently asserting that the "non-transparent and ex parte nature of the internal government procedures" were in some sense "unreasonable." Except in special circumstances involving individual rights or treaty-based guarantees to individuals, however, there are no customary international standards of "due process"2s7; certainly for decisions of the type involved here, no international norms, and nothing in GATT Article $X$, bars one official from conferring with another in her own government about the evaluation of an application from a second government outside the presence of the applicant, and none that compels a formal written and reasoned decision. Absent such a clearly-agreed international standard, it seems questionable to construe the United States practice as "unreasonable" in the context of Article $X$, much less "arbitrary" under Article $X X$. Such a conclusion would mark an unusual intrusion of international law into domestic decision-making procedures.

\subsection{How the Chapeau Relates to the GATT: The Appellate Body's Balancing Test}

The preceding sections have criticized Shrintp-Turtle's specific determinations that various aspects of United States implementation of Section 609 constituted "arbitrary or unjustifiable discrimination." The flaws of reasoning in those sections perpetuate and give additional weight to a WTO jurisprudence that has consistently thwarted appeal by governments to the safe haven of Article $X X$ 's general exceptions from GATT obligations. Unfortunately, the flawed reasoning of Shrimp-Turtle is not limited to the specific facts of that case. Rather, it reflects a more fundamental bias in the WTO approach to the relationship between Article $\chi \chi$ and the rest of the WTO agreements. The nature of this bias becomes clear

247 The concept of "international minimum standards" traditionally applied to state treatment of aliens, and has been broadened in the last half-century to include certain broad minimum standards for criminal convictions, especially as an element of universal human rights. See, e.g., International Covenant on Civil and political Rights, 999 U.N.T.S. 171, art. 14, adopted by U.N.G.A. Res. 2200 (Dec. 16, 1996) (dealing with the concept of international minimum standards). 
from Shrimp-Turtle's articulation of a general approach to the analysis of any Article XX case.

\subsubsection{The Chapeau as a Protection Against Abuse}

The Appellate Body set the general tone of its overarching interpretation of the chapeau with a statement from the negotiating history of Article $X X$, that "the purpose and object of the introductory clauses of Article $X X$ is generally the prevention of 'abuse of exceptions of [Article XX]." 248 Descriptively as well as normatively, prevention of abuse aptly characterizes the general "requirement" in the chapeau. ${ }^{249}$ Article XX does not grant an unconditional license for trade restrictions based on environmental or other goals. On the contrary, as the Appellate Body pointed out, the Article XX exceptions are "limited and conditional"250 - "limited" because they apply in only a few tightly defined circumstances, "conditional" in that government measures get the safe haven of Article XX only if they do not "constitute" a means of 1) "arbitrary" discrimination; 2) "unjustifiable" discrimination; or 3) a "disguised" trade restriction.251 Provisions against arbitrary or unjustifiable discrimination and disguised trade restrictions in other WTO agreements reflect the normative judgment that these particular behaviors so deeply offend the core nondiscrimination and transparency principles of the GATT ${ }^{252}$ that they constitute "abuses" of the exceptions. It is the specific nature of the trifold chapeau "requirement" - that measures not result in arbitrary or

248 AB Report, supra note 9, para. 151 (quoting Reformulated Gasoline, supra note 64 , at 22 (citation omitted)).

249 There are some problems with it, however, as distinguished from an understanding of the chapeau as placing conditions on the use of the Article $X X$ exceptions, conditions that, by their terms, may serve to prevent abuse of Article $X X$ rights.

250 AB Report, supra note 9, para. 157.

251 Id. para. 150.

252 Language guarding against these two abuses is included in other WTO agreements. E.g., SPS Agreement supra note 128, art. 2, para. 3 ("Members shall ensure that their . . . measures ... do not arbitrarily or unjustifiably discriminate... measures shall not ... constitute a disguised restriction in international trade."). See also Treaty Establishing the European Community, Feb. 7, 1992, art. 36, O.J. (C 224) 16-17 (1992) [hereinafter EC TREATY] ("Such prohibitions or restrictions shall not . . . constitute a means of arbitrary discrimination or a disguised restriction on trade...."). The E.C. Treaty language, which roughly parallels GATT Article $\chi X$, omits only the term "unjustifiable." $i d$. 
unjustifiable discrimination or a disguised restriction-that validates the Appellate Body's claim that the chapeau guards against "abuses" of Article XX.

Curiously, however, the Appellate Body in Shrimp-Turtle inverts the logic of the argument, discoursing at length on its normative view of the abuses of trade rights to be prevented, and only then taking up the specific elements of the chapeau. In following such reasoning, it builds up a concept of abuse much broader than can be deduced from the three-part chapeau condition. Remarkably, the Appellate Body itself identified a similar logical weakness at an earlier point in Shrimp-Turtle, noting that it is "very difficult, if indeed it remains possible at all" 253 to decide how the chapeau should prevent abuse if the decisionmaker has not identified which of the Article XX exceptions applies. The Appellate Body correctly noted that the permissibility of certain discriminations may vary depending on whether the measure is one to protect public morals or relates to the products of prison labor. ${ }^{254}$ "Abuse" is thus a relative concept, as it should be. "The location of the line of equilibrium [of rights and obligations], as expressed in the chapeau, is not fixed and unchanging; the line moves as the kind and the shape of the measures at stake vary and as the facts making up the specific cases differ." 255 All the more reason to try to define, in this case for Article $X X(\mathrm{~g})$ purposes, just what patterns of trade discrimination might be "justifiable" or "unjustifiable" before, and as a step towards, developing a broader universal notion of the nature of the abuse to be prevented. Shrimp-Turtle, though, develops its argument from the general to the specific. The preceding sections show

253 AB Report, supra note 9, para. 120.

254 Id.

255 Id. para. 159. Some would argue against this relativity, preferring a more fixed rule. But as Farber and Hudec have observed, after reviewing U.S., EU, and GATT cases, "in some ultimate sense the problem is unresolvable... . No matter how a legal test is articulated, it cannot satisfactorily resolve the tensions between local autonomy and free trade in all conceivable cases. In the end, the law must have a certain irreducible messiness in dealing with such fundamental tensions." Daniel A. Farber \& Robert E. Hudec, GATT Legal Restraints on Domestic Environmental Regulations, in Hudec, supra note 27, vol. 2, at 59, 84. A complex and variable array of factors ought fairly to be evaluated in seeking a modus viczndi for a system of open trade that does not unduly constrain the choices of constituent subsidiary governments in pursuit of important social objectives, such as environmental protection, in ways that conform to local values, traditions, and institutional arrangements. 
the result: the lens of the Appellate Body's general antipathy to unilateral trade measures distorts its reading of the text of the chapeau. Extra-legal policy dictates law.

In approaching the overall interpretation of Article XX, the Appellate Body strongly criticized the panel's very broad formulation that measures which "undermine the WTO multilateral trading system" must be regarded as "not within the scope of measures permitted under the chapeau of Article XX."256 Maintaining, rather than undermining the multilateral trading system is necessarily a fundamental and pervasive premise underlying the WTO Agreement; but it is not a right or an obligation, nor is it an interpretative rule which can be employed in the appraisal of a given measure under the chapeau of Article XX.257 The Appellate Body harked back to its statement in Reformulated Gasoline:

[W] hile the exceptions of Article $X X$ may be invoked as a matter of legal right, they should not be so applied as to frustrate or defeat the legal obligations of the holder of the right under the substantive rules of the General Agreement.... [Article $X X$ measures] must be applied reasonably, with due regard both to the legal duties of the party claiming the exception and the legal rights of the other parties concerned. 258

It is not clear from Reformulated Gasoline, however, just which "substantive rules" of the GATT the Appellate Body has in mind as establishing "rights" of other parties, or just how broadly or narrowly it thinks of those "rights." From this general statement alone, the Appellate Body's idea of "abuse" seems indistinguishable from the Panel's awkward attempt to say that Article XX will not countenance measures that contravene basic "rights" that define the multilateral trading system. The Panel at least expressed its view of what those basic "rights" entail, namely market access and nondiscriminatory treatment. ${ }^{259}$ The Appellate Body, in con-

256 AB Report, supra note 9, para. 116.

257 Id.

258 Reformulated Gasoline, supra note 64, at 22 (quoted in AB Report, supra note 9, para. 151).

259 Panel Report, supra note 7, para. 44. 
trast, never specified the substantive "rights" that it thought deserved "due regard."

On close reading, the Reformulated Gasoline formulation loses coherence. It declares that the actions of a Member taking a measure under Article XX could be said to "frustrate or defeat" its "legal obligations" - a perplexing turn of phrase. It could be read to mean that Article $X X$ does not allow the government taking the action to avoid or escape "obligations" that it owes to other Members, but reading it that way contradicts the plain meaning of Article XX that "nothing in this Agreement" is to be construed to prevent adoption or enforcement of national measures within the permitted categories. Perhaps the Appellate Body really meant to say that Article $X X$ should not allow governments to frustrate or defeat legal "benefits" accruing to other Members.

\subsubsection{Framing the Balancing Test-Dualism and Integration}

Even thus understood, the Reformulated Gasoline language establishes at best an unsatisfyingly vague idea about what government conduct might constitute an "abuse" of Article XX's rights.250 What emerges most distinctly from Reformulated Gasoline is the idea that the allowances for national autonomous action in Article $X X$ must be "balanced" against certain GATT rights and obligations as to which no exceptions whatsoever will be tolerated. An abuse of Article $X X$, then, would be any result that upsets the supposed balance. In a paragraph that raises many issues for analysis, here is how Shrimp-Turtle more explicitly articulates the balancing approach:

Turning then to the chapeau of Article $X X$, we consider that it embodies the recognition on the part of the WTO Members of the need to maintain a balance of rights and obligations between the right of a member to invoke one or another of the exceptions of Article $X X$, specified in paragraphs (a) to (j), on the one hand, and the substantive rights of the other Members under the GATT 1994, on the other hand. Exercise by one Member of its right to invoke

260 As remarked in note 233, supra, a degree of vagueness or "messiness" may need to be tolerated, but that is no excuse for a failure to articulate a coherent and principled general test or set of tangible factors for the case at hand. 
an exception, such as Article $X X(g)$, if abused or misused, will, to that extent, erode or render naught the substantive treaty rights in, for example, Article XI:1, of other Members. Similarly, because the GATT 1994 itself makes available the exceptions of Article $X X$, in recognition of the legitimate nature of the policies and interests there embodied, the right to invoke one of those exceptions is not to be rendered illusory. The same concept may be expressed from a slightly different angle of vision, thus, a balance must be struck between the right of a Member to invoke an exception under Article $X X$ and the duty of that same Member to respect the treaty rights of the other Members. To permit one Member to abuse or misuse its right to invoke an exception would be effectively to allow that Member to degrade its own treaty obligations as well as to devalue the treaty rights of other Members. If the abuse or misuse is sufficiently grave or extensive, the Member, in effect, reduces its treaty obligation to a merely facultative one and dissolves its juridical character, and, in so doing, negates altogether the treaty rights of other Members. The chapeau was installed at the head of the list of "General Exceptions" in Article XX to prevent such far-reaching consequences. ${ }^{261}$

Let us take a closer look at the implications of the balancing test defined here. A balancing test has sound theoretical premises. A treaty should be construed to prevent an abuse or misuse of one right by a Member in a way that would devalue, and ultimately negate, other treaty rights of other Members. But as the Appellate Body acknowledges, Article XX itself creates certain "rights" for WTO Members, and the Article XX rights relate to "legitimate" policies and interests. The balancing test only underscores the need for a clear analysis, within the context of the WTO treaty regime, of just when a unilateral environmentally-based trade measure of one Member can be said to have crossed the line between a valid invocation of the treaty-based Article $X X$ "right" and an illegitimate "abuse" of that right.

261 AB Report, supra note 9, para. 156 (emphasis in original). 
Consider for a moment how the argument about the potential negation of rights might apply if the tables were reversed. Is there not some risk that one Member could abuse or misuse its "right" to trade free of quantitative restrictions in a way that would degrade its own broader treaty obligations and devalue the right of another Member to national action within the scope of Article XX? To put such an argument in the Appellate Body's own language, could one not argue that any interpretation of the Article XX chapeau that gives undue weight to competing trade-oriented rights found elsewhere in the Agreement, "dissolves [Article XX's] juridical character and, in so doing, negates altogether the treaty rights of ... Members" who seek to invoke the protections of Article XX? As the Appellate Body itself said, the rights of Members under Article $X X$ are "not to be rendered illusory." In that sense, too strong an insistence on free market access would be abusive of GATT rights.

What is the scope of the legitimate (non-abusive) rights of Members under Article $X X$ ? In the paragraph quoted above, the Appellate Body strikes its "balance of rights and obligations" in three analytical steps:

1) The Article $X X$ rights of the Members are specified in paragraphs (a) through (j).

2) Those rights are balanced against the countervailing "substantive" rights of other Members (or a Member's obligation to respect those rights).

3) The requirements of the chapeau of Article $\chi \chi$ are meant to prevent abuse of the Article $X X$ rights at the expense of the other "substantive" rights of WTO Members.

This Shrimp-Turtle balancing test is fundamentally dualistic: it compares the competing interests at stake and sets up a construct for weighing the apples of one interest against the oranges of the other. There are several facets to its duality; embedded in each is a policy assumption or perspective that, in the estimation of this author, gives a trade-favoring bias to the test as a whole. The Appellate Body would have done better with an integrated or unitary analysis based on the appreciation that Article $\chi \chi$ is an integral 
element of the GATT and the chapeau an integral element of Article XX. The Appellate Body's dualistic analysis, I will argue, leads to distorted interpretations that would have been avoided by integrating the various rights and interests at stake in a single, internally-balanced whole.

\subsubsection{Article XX Balanced Against the Rest of the GATT}

The first facet of the dualism conceives Article $X X$ as a selfcontained legal statement counterpoised against the rest of the GATT, with the chapeau as the governor "to maintain a balance of rights and obligations between the right of a member to invoke one or another of the exceptions of Article XX... on the one hand, and the substantive rights of the other Members under the GATT 1994, on the other hand." This construct ignores the fact that Article XX, as an original and organic component of the GATT, $a b$ initio conditioned the rights that governments obtained and the obligations they undertook in the rest of the Agreement. Even the League of Nations draft of 1927 contained a provision very close in language as well as in spirit to the current Article XX.262 By its very essence, Article $X X$ describes the relationship of its exceptions to the rest of the GATT, so the rest of the GATT must be read with the recognition that Article $X X$ constitutes an integral part of the overall structure of rights and obligations created by the Agreement. It is not an exaggeration to suggest that the original parties in 1947 would never have concluded a General Agreement that did not contain Article XX.263 The challenge for the Appellate Body, then, was to integrate within an interpretation of the GATT as a whole meaningful allowance for derogations from its core principles. The dualism of the Shrimp-Turtle analysis ducks this challenge, and thus fails to develop an appreciation of the nature of the multilateral trading system within which the Article $X X$ exceptions would have a clear and reasonable function.

262 Steve Charnovitz, Exploring the Environmental Exceptions in GATT Article XX, $25 \mathrm{~J}$. WORLD TRADE, 37, 41-42 (1991). The 1927 language actually foreshadows the E.C. Treaty language, supra note 252 , in that it precludes arbitrary discrimination and disguised trade restrictions but omits the added term "unjustifiable" that occurs in Article XX. EC TREATY art. 36.

263 This is more obviously true of the much larger membership of the WTO, now 142, who subscribe to the GATT 1994, which reinforced Article XX with important preamble language on environmental protection and optimum use of resources. 
One of the cardinal principles of treaty interpretation-the principle that any specific provision should be read in relation to the purposes of the treaty as a whole 264 - points the way to an integrative approach to Article $X X$. This principle supports the Appellate Body's endorsement of the long-standing GATT practice to construe the Article $X X$ exceptions narrowly.265 After all, "general exceptions" by definition tend to run contrary to the main tenets of the treaty of which they are a part, so they should be available only in the precise circumstances for which they were created. By the same token, however, the exceptions must be given meaningful effect. They should not be so narrowly interpreted as to make them less than the "general" exceptions they declare themselves to be.

The limited nature of the overall GATT regime provides a key to defining Article $X X$ 's proper role. The principal function of the GATT, not only when originally adopted in 1947 but when WTO Members committed themselves to it anew in 1994, is "to develop an integrated, more viable and durable multilateral trading system" and "to preserve the basic principles and to further the objectives underlying this multilateral trading system." $2 \in 5$ Such language begs a further inquiry: what are the basic principles underlying this multilateral trading system, and what are its objectives?

When originally adopted, and as it operates today, the GATT yields significant elements of economic policy making to a multilateral system of mutual restraint and obligation. But the system is neither absolute nor all-encompassing. The GATT is replete with qualifications and exceptions that soften the effect or limit the reach of even its central tenets. ${ }^{267}$ These qualifications and excep-

264 Vienna Convention on the Law of Treaties, May 23, 1969, art. 31.1, para. 1, 1155 U.N.T.S. 331, 340, art. 31.1 [hereinafter Vienna Convention] (providing that: "[a] treaty shall be interpreted in good faith in accordance with the ordinary meaning to be given to the terms of the treaty in their context and in light of its object and purpose.").

265 See, e.g., United States-Section 337 of the Tariff Act of 1930, Nov. 7, 1989, GATT B.I.S.D. (36th Supp.) at 345, 373-76 (1990) (applying "necessary" test to Article XX(d)); GATT Dispute Settlement Panel Report, Thailand-Restrictions on Importation of and Internal Taxes on Cigarettes, Nov. 7, 1990, 30 1.L.M. 1122, 1129-32 (applying "necessary" test to Article XX(b)).

266 GATT pmbl.

267 See, e.g., ROBERT GILPIN, Global POLTICAL ECONO:MT: UndersTanotic the INTERNATIONAL ECONOMIC ORDER 218 (2001) ("[T] he principles of the GATT regime were significantly qualified by escape clauses and exceptions ...."). A few 
tions reinforce the observation that Members have shielded many elements of national policy from the full force of the GATT obligations. They yielded only so much of their economic policy-making authority as they saw fit in order to secure the advantages of international trade, while maintaining freedom of national action in especially sensitive policy areas or for the protection of politically important national prerogatives.268 Even the most sacrosanct GATT principles-most-favored-nation, national treatment, and the prohibition on quantitative restrictions - are hedged with exemptions and qualifications within the GATT besides Article $X X$. In short, the GATT is an agreement of limited and carefully defined obligations. ${ }^{269}$ Among the many areas for which the WTO Members retained national prerogatives for autonomous action are the areas of public policy specified in the lettered paragraphs of Article XX.

examples illustrate the point: Article III:8 exempts government procurement from the national treatment obligations of the Article III; Article XII allows a nation to impose quantitative restrictions, notwithstanding Article XI, "in order to safeguard its external financial position and its balance of payments"; Article XIX allows parties to "suspend" obligations or "withdraw" concessions in response to surges of imports that threaten "serious injury" to domestic producers; Article XXIII relaxes GATT obligations, such as the most-favored-nation obligation, to facilitate the creation of customs unions and free trade areas.

268 John Gerard Ruggie coined the oft-cited term "embedded liberalism" to capture the point that liberal international trade policy is "embedded" within the politics of national economic policies, including policies on the domestic distribution of the welfare gains of trade, and allows such key economic policy decisions to continue to be made at the national level. John Gerard Ruggie, International Regimes, Transactions and Change: Embedded Liberalism in the Postwar Economic Order, 36 INT'L ORG. 379 (1982). See also Dunoff, supra note 45, at 1409-10 (applying Ruggie's analysis in the "trade and..." context).

269 There are obvious parallels to the limited nature of the powers of central governments vis-à-vis constituent states in the United States constitutional system and in the European Union. In each case, the constituent states retain broad prerogatives that may, from time to time, result in state measures that interfere with the constitutional or treaty-based value of free interstate commerce/the free movement of goods. It is worth noting, as part of the parallel between these systems and the WTO, that the United States, which has the longest history of a "single market," exercises the strictest control over state interference with interstate commerce in the name of environmental protection. The European Union, which is more recent and is composed of sovereign nations, shows somewhat greater tolerance for national environmental measures with trade effects. See generally Farber \& Hudec, supra note 255. By analogy, the WTO, which is simply a mutual system of trade rules and has no pretensions to the creation of a single market, should accept an even wider area of discretion for national governments to protect their environments even at some cost to liberal trade. 
A careful look at the objectives of the WTO membership in giving new life to the GATT in 1994 confirms the special appropriateness of Article XX's policy space for national action with respect to protection of the environment. A truism often reaffirmed by trade policy advocates themselves in the trade-environment dialogue holds that the multilateral trading system is not valued as an end in itself, but as an effective means for meeting important world objectives. As summarized in the WTO Preamble's first two paragraphs, 270 those "objectives" turn out to be rather complex. Of particular relevance for the interpretation of Article XX, the objectives for GATT 1994 explicitly include not only "optimal use of the world's resources" (which has strong overtones of economic efficiency) but also the desire to "protect and preserve the environment," and, in addition, to "enhance the means for doing so." The only notable qualification on these statements is that environmental protection efforts should respect the "needs and concerns" of WTO Members "at different levels of economic development."

In Shrimp-Turtle, the Appellate Body took note of this Preamble language and paid some lip-service to the values it expresses, saying that it gives "colour, context, and shading to the rights and obligations of Members under the ... GATT 1994."271 But making the

270 GATT pmbl:

The Parties to this Agreement,

Recognizing that their relations in the field of trade and economic endeavour should be conducted with a view to raising standards of living, ensuring full employment and a large and steadily growing volume of real income and effective demand, and expanding the production of and trade in goods and services, while allowing for the optimal use of the world's resources in accordance with the objective of sustainable development, seeking both to protect and preserve the environment and to enhance the means for doing so in a manner consistent with their respective needs and concerns at different levels of economic development,

Recognizing further that there is need for positive efforts designed to ensure that developing countries, and especially the least developed among them, secure a share in the growth in international trade commensurate with the needs of their economic development....

Id.

271 AB Report, supra note 9, para. 155. In the same vein, it also uses the Preamble language to confirm its interpretation of Article $X X(\mathrm{~g})$ as covering living as well as non-living resources. Id. para. 131. 
preamble into a fashion statement about "colour, context, and shading" denigrates the importance of the environmental objectives and thereby gives the trade promotion objectives of the GATT a disproportionate significance. To be sure, the terms of the operative provisions of the treaty, not the preamble, should be the main guide for interpreting its meaning. But the Vienna Convention expressly embraces the "preamble and annexes" of a treaty within the treaty "text" that is the foundation for interpretation. ${ }^{272}$ When the Appellate Body steps back to view Article XX in the context of the GATT as a whole, it discredits the negotiations over environmental issues that lie behind the Preamble when it says that this language gives only "colour" and "shading" to the trade provisions. In particular, it ignores the trade ministers" contemporaneous commitment to remove "policy contradictions" between trade and environment.273

The Appellate Body also discredits the intent of the ministers in 1994 when it says that "they decided to qualify the original objectives of the GATT 1947" with the preamble language..$^{274}$ In putting the issue in those terms, the Appellate Body forgets that the GATT 1994 is, legally speaking, a wholly new agreement.275 Each member of the WTO, not only new entrants but also each original party to the GATT 1947, has newly ratified the GATT 1994. The words are the same as the GATT 1947, and the basic thrust remains the same, but the 1994 preamble marks a fresh start at defining trade policy objectives for the WTO members in the context of the late twentieth century. The Preamble, then, does not merely "qualify" the 1947 objectives, it replaces them with a new set of objectives. The words of the GATT 1994 have henceforth to be read in that new light, with rather less consideration to the postwar circumstances of their original negotiation fifty years earlier.

The heads of state of the WTO Members endorsed the Rio Declaration and Agenda 21 just two years before Marakkesh providing further contemporaneous evidence of the political impulse motivating the WTO Preamble. In language that trade advocates like to quote, Principle 12 of the Rio Declaration and Chapter 2 of

\footnotetext{
272 Vienna Convention, supra note 264, art. 31, para. 2.

273 Marrakesh Decision, supra note 1.

274 AB Report, supra note 9, para. 152.

275 GATT, supra note 4.
} 
Agenda 21 observe that international trade and environmental protection can and should be "mutually supportive."276 In part, this language reasserts the article of faith among WTO Members that a liberal international trade system can promote environmental protection objectives. Mutual support, however, connotes reciprocity in the relationship. In the Rio Declaration, then, the governments were also declaring that policies promoting the protection of the environment contribute to the objectives for which those governments maintain the multilateral trading system. Indeed, the use of "should" in the Rio clause makes it a normative declaration that these two spheres of policy ought be managed so as to maintain and enhance their positive interaction, a position reaffirmed in the WTO Preamble. Though the same paragraph of the Rio Declaration expresses a familiar and unexceptionable preference for multilateral approaches to environmental protection and warns that unilateral approaches should be "avoided," such language clearly does not preclude unilateral action altogether. $2 \pi$

\subsubsection{The Chapeau Balanced Against the Paragraphs of Article XX}

The Shrimp-Turtle balancing test also shows dualism in setting up the chapeau of Article $X X$ as a legal test distinct from the subsequent paragraphs (a) through (j) that it introduces. At one point the Appellate Body states that, "Any measure, to qualify finally for exception, must also satisfy the requirements of the chapeau."273 At another point, the Appellate Body frames this same distinction in terms of the chapeau as a "prevention" of abuse by Members of the permitted exceptions.279 As a matter of judicial economy, it certainly makes sense to determine if the measure at issue is even within the ambit of the lettered paragraphs of Article $\chi \chi$ before embarking on the more fact-specific and contentious judgment whether it was applied in a manner that results in unacceptable forms of trade discrimination or trade restriction. It may also be sensible to characterize that requirement as a protection against

276 Agenda 21, supra note 3, para. 221.

277 See, e.g., Howse, supra note 25, at 96 ("[T] hibit unilateral environment measures.") (emphasis in original).

278 AB Report, supra note 9, para. 157.

279 Id. para. 151. 
particular anticipated "abuses" of the Article $X X$ general exceptions. But it is quite another matter to set the chapeau up as a second hurdle, rather than as part and parcel of a single test. The first clause of the chapeau is not written, and should not be construed, as defining a legal balance between two conflicting rights. An alternative, integrative analysis faithful to the text recognizes the chapeau as a condition on the use of the lettered exceptions rather than as a protection against their misuse. The difference is important. If the listed exceptions are conditional $a b$ initio, then they can be fully and freely exercised as long as those conditions are satisfied. In that sense, they are not subject to abuse, and there is no need to "prevent" possible abuse. The Appellate Body's claim that the chapeau of Article XX was "installed at the head of the list of 'General Exceptions' to prevent such far-reaching [GATT-eroding] consequences" is altogether too grandiose a description of language guarding against a few specified effects. The chapeau is neither the first nor the last line of defense protecting the GATT structure against all diminishment. It is a limited and conditional restraint on the exercise of certain national rights that have never been yielded by governments to multilateral trade control. Both the text and the context of the chapeau confirm this view.

The language and structure of Article $X X$ make the chapeau an integral part of the Article, not a separate principle or separate test. The chapeau itself has two clauses. The language setting forth the "requirements" or conditions on resort to Article $X X$, which the Appellate Body isolates, appears at the beginning of chapeau, but in a subordinate clause. The limits and conditions of this clause make no sense except in their subordinate relationship to the ensuing main clause of the sentence. It is the main clause that expresses the central purpose of Article $X X$ : "[n]othing in this Agreement shall be construed to prevent the adoption or enforcement by any Member of measures" having the objectives and characteristics listed in the lettered paragraphs that follow. The unambiguous policy statement of Article XX (also reflected in the title given to the Article, "General Exceptions") establishes that WTO Members cannot be prevented by any aspect of their GATT commitments from adopting and enforcing trade measures in the listed categories. Like similar clauses in contracts, statutes, and other treaties, Article XX exempts certain activities of the parties, or certain of their rights and interests, from any application of the 
agreement in any respect whatsoever. Article $X X$ can be thought of as a negotiated reservation, an agreement by the parties that, from the outset, they reserved to themselves their existing rights as governments to take action in certain spheres of interest, and that the mutual obligations they were undertaking in the general realm of international trade did not extend to trade measures relating in defined ways to those non-trade spheres of interest.

Contextually, Article XX establishes the rights of Members to take certain trade actions notwithstanding their agreement to the mutual rights and obligations of the GATT. The first clause of the chapeau should be read so as to give expression to that central purpose. To be sure, the clause puts certain conditions on that central purpose, but just as Article $X X$ is construed narrowly vis-àvis the rest of the GATT, so too should the three elements of the chapeau "requirement" be read narrowly in conditioning the broad rights that they introduce. 280 The language of the chapeau - "Subject to the requirement ...."-indicates that the chapeau expresses a single limitation on the rights of Article $X X$. It should be read to limit those rights only according to the specific elements that give definition to that "requirement." The chapeau does not offer broad-brush protection against all possible "abuses" of free-trade interests that come to the imagination; it protects the so-called "substantive rights" of the GATT only against the particular "abuses" of arbitrary or unjustifiable discrimination or disguised trade restrictions. All other consequences of national measures to conserve natural resources are to be tolerated, whether or not they are thought to "undermine," "degrade," "devalue," or even in a particular case to "negate," the core principles of an idealized "system" of multilateral trade.281

280 As Howse puts it:

This goes back to the principle of in dubio mitius ... which was applied by the Appellate Body in Hormones: unless they have done so in explicit language, parties to a treaty should not normally be assumed to have ceded sovereign rights and prerogatives that they possess under the general principles of international law.

Howse, supra note 25, at 95-96.

281 Howse makes the further observation that the lettered paragraphs contain their own tailor-made protections against abuse (e.g., measures under (b) must be "necessary"; measures under (g) can only be "in conjunction with domestic restrictions"). He concludes: "This is all the more reason why the language "unjustifi[able] discrimination" in the chapeau should not be read so as to create 
Both the historical antecedents to Article $X X^{282}$ and the subsequent negotiation of similar conditions on national action in the Agreement on the Application of Sanitary and Phytosanitary Measures 283 ("SPS Agreement") support an integrated view of the exceptions as conditional exceptions, and imply no broader concern about abuses of the rights reserved to the Member states. The SPS Agreement was negotiated as, and is phrased as, a set of international limitations on actions that remain, in principle, national prerogatives, not as a grant to Member nations of rights they would not otherwise have. ${ }^{284}$ The Appellate Body's own interpretation of the SPS Agreement in Beef Hormones follows such an approach. SPS measures are not suspect in principle; they are simply subject to a number of specific constraints and conditions, each of which is described in the text of the agreement.285 In either case, the connection between the conditions of the agreements and the rights of action in the listed paragraphs is best read as an international guarantee of continued freedom of national action in these sensitive policy spheres, with a few conditions placed on that freedom in keeping with the overall international trade regime being

broad constraints on particular classes or kinds of measures." Howse, supra note 25 , at 84 .

282 See supra text accompanying notes 146-47.

283 SPS Agreement, supra note 128. $X X:$

284 The preambular paragraph of the SPS Agreement closely parallels Article

Reaffirming that no Member should be prevented from adopting or enforcing measures necessary to protect human, animal or plant life or health, subject to the requirement that these measures are not applied in a manner which would constitute a means of arbitrary or unjustifiable discrimination between Members where the same conditions prevail or a disguised restriction on international trade....

Id. The basic rights and obligations declared here are restated in slightly different words in the operative articles of the Agreement. Article 2.1 affirms that "Members have the right" to take SPS measures, while Article 2.3 enjoins them to "ensure" that they do not discriminate arbitrarily or unjustifiably. Id.

285 Beef Hormones, supra note 131, para. 172. Beef Hormones states that the right of a Member to set its own level of health protection is an "autonomous" right, not an exception from a general obligation to base measures on international standards. Id. In this context, it later concludes that the European Union was pursuing multiple objectives in its regulations on hormones, and therefore overturns the Panel's conclusion that patterns of seemingly inconsistent regulation resulted in "arbitrary or unjustifiable" discrimination under the SPS Agreement. Id. paras. 245-46. 
established. From this perspective, the chapeau language of Article $X X$ should be interpreted narrowly so as to preserve national prerogatives, and not as broad shield against diverse protectionist "abuses" impairing liberalization of international trade.

The dualism of the Shrimp-Turtle's balancing test, construing the chapeau as the embodiment of the WTO's "recognition . . . of the need to maintain a balance of rights and obligations" between the Article XX rights of one Member and the "substantive rights of the other Members," permits the trade-centered principles of the GATT to outweigh the exercise of reserved national rights under Article XX. Such a construction arrogates to the dispute settlement panels and the Appellate Body the authority to impose, after all, some GATT trade constraints on national resource conservation measures, contrary to the clear command of Article XX that "nothing" in the GATT should restrain the exercise of the authorized national prerogatives.

\subsubsection{Substantive vs. Insubstantial GATT Rights}

The Appellate Body unbalances its balancing test even further with a third duality: the "treaty rights" of Article XI:1 (and, one assumes, Articles I and III at least) are said to be substantive, while the rights of unilateral action under Article $X X$ are, for some vague and unexplained reason, relegated to an unspecified but otherthan-substantive nether realm. In six consecutive sentences, the Appellate Body counterposes the simple, unmodified Article $X X$ "right" against the trade-enhancing substantive or treaty rights of Members. Article XI.1 is one example: "[e]xercise by one Member of its right to invoke an exception, such as Article $X \times(g)$, if abused or misused, will, to that extent, erode or render naught the substantive treaty rights in, for example, Article XI:1, of other Members." Like the ruling elite of George Orwell's Animal Farm, the Appellate Body has apparently decided that although all GATT rights are equal, some are more equal than others.

This third dualism only reinforces the first two, but its implications are more disturbing. The GATT makes no distinction of status among its different rights and obligations. One might speak, as lawyers habitually do, of certain rights as "substantive" (for example, the right to most-favored-nation treatment) in comparison to other rights that are essentially "procedural" (such as the right to consultation under Article XXII). But the Slrrimp-Turtle language 
goes well beyond such simple analytical utility to create the distinct impression that some of the "substantive" rights, like MFN, are more substantive (or at least more deserving of being labeled "substantive") than the substantive Article $X X$ rights of national action. Consciously or unconsciously, the Appellate Body thereby conveys a profound bias in favor of all Member rights that expand the scope and authority of multilateral trade disciplines and a bias against all rights of the same Members to act in ways that express or protect national interests. A more balanced, historically honest, and analytically sound approach would clearly acknowledge that the whole GATT and WTO fabric weaves the warp of multilateralism into the woof of national autonomy, with neither being in any way the more "substantive" of the Members' interests.

The multiple analytical dualities described in this section put into the scales of WTO justice certain unconditional substantive rights and principles of the GATT that are weighed against legitimate but implicitly subordinate national interests. This uneven balancing test lacks the equilibrium the Appellate Body set out to define. As applied in Shrimp-Turtle, potential or abstract discriminations in the way a unilateral measure operates tip the scales against the government that takes an Article XX measure regardless of the significance of the national-indeed international-conservation interest it seeks to advance.

\section{AN ALTERNATTVE APPROACH TO ARTICLE XX}

Section 4 of this Article has found multiple, serious flaws in the Appellate Body's interpretation of the Article XX chapeau. It has also raised the concern that Shrimp-Turtle's Article XX jurisprudence has already had, and will continue to have, a corrosive effect on the ideological framework of shared principles that supports constructive trade-environment policy dialogue. Without a constructive dialogue in both civil society and the WTO, the muchdesired but seldom-achieved patterns of "mutual support" between trade and environmental policy will remain unattainable. This Article's sharp criticisms of Shrimp-Turtle naturally raise the following question: are there plausible reconstructions of the chapeau that could restore the lost balance between trade and environmental objectives and make Article $X X$ a useful element of the overall structure of trade policy? I contend that such reconstructions are possible. They can be created within the current institu- 
tional context without a serious weakening of the safeguards that shield open, nondiscriminatory, and equitable trade from narrowminded protectionist assaults.

The proposed reconsideration of Article $\chi \chi$ has two aspects. One is a question of substantive law: what should be the legal content of a reconstructed Article $X X$ interpretation? The other is an institutional and procedural issue: who would reconstruct the Article $X X$ interpretation and how would that be accomplished? Because the choice of institutional and procedural strategy depends in part on the nature of the substantive change being proposed, this Section of the Article will address the substantive issues first (Section 5.2.), and then consider how to introduce the proposed reinterpretations into the system (Section 5.3.). This Section prefaces that discussion with a more general consideration of the conflicts that may arise under Article $X X(\mathrm{~g})$ and the legal issues that call for decision in cases involving transboundary resources (Section 5.1.).

Other fundamental problems with the trade policy structure also need to be addressed if the WTO is to play a lasting role in promoting sustainable development. One is the general bar to trade measures based on processes and production methods ("PPMs"). The GATT sets the framework for policies about trade in products themselves. It is an article of faith in trade circles that governments should not be permitted to condition access to their markets on compliance with any unilaterally-determined PPMs that are not related to the product itself. Opening the policy door to PPM-linked trade measures raises such complex, uncomfortable choices that most WTO members have so far taken an intransigent "just say no" attitude.286 As an exceptions clause, however, Article $X X$ would and should excuse from this anti-PPM bar any national trade restriction for the qualifying purposes. A more modest ob-

286 Howse and Regan have advanced a provocative argument that neither "the text and jurisprudence of GATT ... support[s] the process/product distinction" and that is premised on faulty conceptual and policy arguments. Robert Howse and Donald Regan, The Product/Process Distinction-An Mlusory Basis for Disciplining "Unilateralism" in Trade Policy, 11 EUR. J. INT'L L. 249, 252 (2000). In a response in the same journal, Jackson questions their analysis, saying that it "generally misses the real issues that the trade policy institutions are forced to address." John H. Jackson, Comments on Slurimp-Turtle and the Product Prouss Distinction, 11 EUR. J. INT'L L. 303 (2000). 
jective, then, is to ensure that Article $X X$ effectively permits environmentally-based trade measures.

\subsection{The Three Dimensions of Trade-Environment Conflicts}

The trade and environment dilemma posed by the relationship between shrimp trawling and sea turtle protection has three dimensions, drawn from earlier trade-environment conflicts: jurisdiction; values; and a tension between trade and environment policy.

Jurisdiction shapes the issue because a geographic and hence jurisdictional asymmetry exists between economic cause and environmental effect. Given current technology, the regulation of shrimp trawling intensity and equipment is an essential means of achieving sea turtle protection. The economic activity of shrimp trawling is local; its regulation has traditionally been a matter for national governments to determine. Sea turtles, though, are migratory so the ecological consequences of local shrimping transcend national boundaries, affecting the distribution of sea turtles worldwide and threatening the survival of particular breeding stocks of sea turtles in distant countries. Under these circumstances, all agree that truly effective protection of sea turtles can be secured only through a collective response at the international level. But a worldwide turtle conservation regime has yet to be developed or even discussed seriously among governments. In the meantime, should individual nations be allowed to take steps to protect sea turtles even though those steps, to be ecologically effective, must cross jurisdictional boundaries? To put the question in more provocative legal terms, do the wanderings of sea turtles across jurisdictional boundaries justify extraterritorial reach for unilaterally determined shrimp trawling rules?

The jurisdictional asymmetry between cause and effect takes on a sharper edge from a second dimension of the controversy, the diversity of values and circumstances among the many countries involved. The people who trawl for shrimp make their livelihood from it and contribute, often significantly, to the economic welfare of their home countries. Sea turtles, on the other hand, have little commercial value, thanks in part (ironically) to recent legal prohibitions on their direct exploitation. Their value derives from more abstract ecological concerns relating to biodiversity conservation infused with moral concern about human responsibility for possi- 
ble extinction of species that have survived the vicissitudes of nature for over 100 million years.287 Consequently, in weighing the benefits of shrimp trawling against the dangers it poses to sea turtles, different individuals and different nations can be expected to make divergent policy choices depending on their economic standing, their cultural preferences, and even their moral outlook on man and nature.288 These national differences have two consequences that make the Shrimp-Turtle dilemma intractable. On the one hand, values diversity impedes formation of a multilateral turtle protection regime. On the other hand, it empowers those who reject the extraterritorial effects of unilateral measures as infringements on national autonomy and sovereignty. In this way, values create a legal Catch-22 in which nations are reluctant to create a multilateral turtle protection regime but object to unilateral measures toward the same objective.259 Only appeal to more gen-

287 Christopher Stone, taking a phrase from the Talmud - "the gnat is older than he $e^{\prime \prime}$-makes a moral argument for humility by man in relation to nature in these circumstances. Christopher D. STONE, THE GNAT is OLDER than MAN: GLOBAL ENVIRONMENT AND HUMAN AGENDA 280 (1993).

288 If the protection of sea turtles were a uniquely American pre-occupation, as was arguably the case with dolphin protection in the tuna-dolphin cases (with the exception of one species, dolphin protection was not based on the endangered status of dolphins or their ecological role), many would argue that morality cannot justify the United States policy and other nations should be allowed their diverse views. For example, Jagdish Bhagwati and T.N. Srinivasan, Trade and the Environment: Does Environmental Diversity Detract from the Case for Free Trade, in Hudec, supra note 27 , at 159 , make the argument that ethical preferences do not justify trade policies to compel harmonization of environmental standards. Professor Stone would agree. He has made the statement, "Dogmatism has no place, least of all in morals." CHRISTOPHER D. STONE, EARTH AND OTHER ETHIC: THE CASE FOR MORAL PLURALISM 259 (1987). But the commitment to make efforts to prevent the extinction of species, while not without a moral element, has attained the status of a universal norm in international environmental affairs. The Asian complainants in the WTO Shrimp-Turtle dispute agreed with the widely-shared international view that sea turtles should be protected. For example, India commented: "[i]n general we agree with the views of [an expert] that all measures that prevent sea turtles from being killed are important." Panel Report, supra note 7, para. 5.301. Unlike the tuna-dolphin cases, then, the differences in environmental views among the parties in the Shrimp-Turlle dispute centered on shrimp trawling equipment as the main means of sea turtle protection, not on any clash about the fundamental objective of saving sea turtles from extinction.

289 This describes the attitude of Malaysia in particular in the shrimp-turtle dispute. It has shown no particular eagerness for a strong multilateral regime, and at the same time strenuously argued against the unilateralism of Section 609. See generally Recourse Panel Report, supra note 17. 
eral principles, such as the responsibility to care for sea turtles as a "common concern of mankind," 290 offers escape from the dilemma.

The preoccupation of economic actors and their governments with competitiveness in international markets gives the ShrimpTurtle issue its third dimension, the conflict between trade objectives and environmental protection. Most governments favor trade over the environment where the two policy objectives come into conflict. The economic value of shrimp trawling for each country depends on the ability of its trawlers to compete in a global market against trawlers and shrimp farmers from other countries, while effective sea turtle conservation depends on protecting turtles from incidental take in all waters where they occur. As noted before, it would be ideal to protect sea turtles through a binding multilateral agreement, but formidable diplomatic obstacles have so far precluded the necessary consensus. ${ }^{291}$ A distorted view of competitiveness concerns creates corresponding barriers to unilateral measures. Any national regulation of shrimping that is perceived to affect the competitiveness of domestic shrimpers will be resisted. ${ }^{292}$ But once a nation overcomes those domestic forces and takes steps to protect turtles from commercial shrimping, shrimpers in that nation will generate political pressure for rules to get other nations to adopt similar regulations. In the words of the Rio Declaration, however, "[u]nilateral measures to deal with environmental challenges outside the jurisdiction of the importing country should be avoided." 293 Once again, the prevailing political

290 I refer to "common concern of mankind" because sea turtle conservation indisputably meets that criterion. It is a specific example of the obligation to conserve biological diversity, which is denoted a "common concern of mankind" in the Convention on Biological Diversity. With respect to sea turtles, one could make a strong argument that they are, in fact, part of the "common heritage of mankind," a designation that implies even stronger protective obligations on all nations.

291 In Parker's view, the history of tuna-dolphin "clearly refutes the assumption of free traders and legal optimists that 'management' alone will suffice to protect the truly global commons .... Moreover, the reasons for the presumed necessity of ETL [environmental trade leverage] in cases like tuna-dolphin are clearly set forth in neoliberal IR [international relations] theory." Parker, supra note 13 , at $99-100$.

292 There was a vehement, almost violent, reaction by the United States shrimp industry to the required use of turtle excluder devices. Shrimpboats Blockade Pass to Protest Turtle Devices, UPI, July 22, 1989, available at LEXIS, ARCNEWS File.

293 Rio Declaration, supra note 132, at 878. Principle 12 goes on to declare: 
norms and legal systems slow the formation of international environmental cooperation and then privilege national autonomy based on economic considerations to frustrate individual national responses to the same environmental problem.

Of the three dimensions just described, the first two lie beyond the reformative reach of law and politics. Jurisdiction inheres: genetics determine the life-cycle of sea turtles, and centuries-old patterns of political organization by nation-states prescribe jurisdictional boundaries and rules. Economic and cultural differences within and among nations likewise have deep roots in established circumstances of the world that will not change appreciably without radical social transformations. Legal strategies for sea turtle conservation at the national and international levels therefore must account for the jurisdictional asymmetries and the diversity of values among countries. The United States policy in enacting and implementing Section 609 should be evaluated with those considerations in mind.

By contrast, the third dimension of the dilemma, the tradeenvironment tension, can be addressed in the near term by legal and policy development. The tension between international trade disciplines and environmental protection measures, after all, is simply an artifact of prevailing constructions of international law. The dissonance can be resolved, if nations will, by nonrevolutionary policy choices-by designing rules and institutions so as to establish a new balance of legal powver between economic interests and ecological interests. The only question would be just how to remove, in trade ministers' own words, "any policy contradiction" between the multilateral trading system and the promotion of sustainable development.294

International agreement rhetoric indicates suitable objectives for such legal reform. Chapter 2 of Agenda 21 proclaims a normative construct: "Environment and trade policies should be mutually supportive." ${ }^{295}$ It then charges governments to strive to meet a

\footnotetext{
"Environmental measures addressing transboundary or global environmental problems should, as far as possible, be based on international consensus." Id.

294 WTO, Releoant WTO Provisions: Text of 1994 Decision, 4 IssUES IN THE WTO, at http://www.wto.org/english/tratop_e/envir_e/issu5_e.htm (last visisted Dec. 5, 2001).

295 Agenda 21, supra note 3, para. 219 (setting forth the "basis of action" on making trade and environment mutually supportive).
} 
corresponding objective: "To make international trade and environment policies mutually supportive in favour of sustainable development."296 Although "sustainable development" eludes specific definition, 297 it embraces the conservation of biodiversity in general,298 and the avoidance of extinction of species in particular. 299 Thus, for international trade and environmental policies to be mutually supportive one element of their reciprocal relationship must be an assurance that international trade disciplines will not thwart environmentally sound policies that protect endangered species such as sea turtles. WTO dispute settlement ought not to be the primary forum for such legal and institutional reform toward sustainable development, but the Appellate Body can, and should, play a constructive role by interpreting the WTO agreements with more sensitivity to the environmental policy implications of its decisions. ${ }^{300}$ The focal point for those decisions has

296 Id. para. 2.21(a) (stating the "objective" corresponding to the basis of action).

297 One writer captures the definitional problem with the observation that "sustainable development is a contestable concept" - a broad and widely shared concept, often a goal, as to which the specific content or mode of implementation is open to reasonable, and continual, debate. MiCHAEL COMMON, SUSTAINABILITY AND POLICY: LIMITS TO ECONOMICS 222 (1995). Other examples of "contestable concepts" include "democracy" and "justice." The conceptual "contest" over sustainable development plays out in an almost limitless literature. A few examples of legal analysis grappling with the definitional aspect include Günther Handl, Sustainable Development: General Rules versus Specific Obligations, in SUSTAINABLE DEVELOPMENT AND INTERNATIONAL LAW 35 (Winfried Lang ed., 1995); John C. Drnbach, Sustainable Development as a framework for National Governance, 49 CASE W. Res. L. Rev. 1 (1998); Helen Endre-Stacy, Sustaining ESD in Australia, 69 CHI.KENT L. REv. 935 (1994); David R. Hodas, The Role of Law in Defining Sustainable Development: NEPA Reconsidered, 3 WIDENER L. SYMP. J. 1 (1998); David Wirth, The Rio Declaration on Environment and Development: Two Steps Forward and One Back, or Vice Versa?, 29 GA. L. REv. 559 (1995).

298 Another major agreement signed in Rio de Janeiro at the U.N. Conference on Environment and Development was the Convention on Biological Diversity, June 5, 199231 I.L.M. 818 (entered into force Dec. 29, 1993).

299 I cite here the strong moral statement by biologist E.O. Wilson that the loss of biological diversity is, "the folly for which our descendants are least likely to forgive us." Edward O. Wilson, The Conservation Ethic, in BIOPHILIA 119, 121 (1996). Paragraph 15.5(g) of Agenda 21 exhorts governments to, "take action where necessary for the conservation of biological diversity through the in situ conservation of ecosystems and natural habitats ... and the maintenance and recovery of viable populations of species in their natural surroundings...." Agenda 21, supra note 3.

300 I agree in large part with Jeffrey Dunoff, who recently asserted that, "it is 
been, and presumably will continue to be, the application of GATT Article $X X$. The WTO cannot fulfill its own responsibilities under the Rio Declaration and Agenda 21 unless and until the Appellate Body, or some other part of the WTO, formulates an interpretation of Article XX that gives individual governments ample authority to deploy trade measures in support of public health protection and resource conservation.

\subsection{Fresh Interpretation of the Article XX Chapenu}

As argued in Section 4 above, the problem with the current application of Article $X X$ is not with the words of the GATT text themselves, but with the unnatural gloss the Appellate Body has put on them. A suitable resolution of the problem does not, therefore, require an amendment to the GATT. Much of the tradeenvironment tension could be alleviated by a comprehensive, definitive, and jurisprudentially conservative reconsideration of Article $X X$-the conditions it imposes, the tests it creates.

What matters is whether the words now in the GATT are understood to accommodate, or could be interpreted to accommodate, national environmental initiatives. It has often been said that the GATT nowhere mentions the word "environment," but the absence or appearance of the word is not a critical issue. There are several reasons not to insist on introducing the word "environment" into the GATT text. The WTO members made clear in the preamble to the Agreement Establishing the WTO that the agreements were meant to further, and international trade should be managed to ensure, "the optimal use of the world's resources in

politically naive to urge WTO panels to "struggle openly" with the value conflicts raised by "trade and" issues," and that cases raising such issues "threaten to delegitimize WTO dispute resolution." Jeffrey L. Dunoff, The Death of the Trade Regime, 10 EUR. J.INT'L L. 733, 754, 756 (1999). But against a possible charge of being politically naive, I am not asking for a free-form resolution of value conflicts, but for a more rigorous interpretation of the existing text, which I believe already allows some scope for trade measures in the name of environmental protection. GATT interpretation is the central function of dispute settlement. Moreover, Professor Dunoff appears to be focusing on the role of ad hoc dispute settlement panelists, whereas I am addressing my arguments for a better-proportioned textual interpretation to the Appellate Body, a permanent group situated within the structure of the WTO, and ultimately to the Council of the WTO members. Cf. G. Richard Snell, Trade Legalism and International Relations Theory: An Analysis of the World Trade Organization, 44 DUKE L.J. 829, 910 (1995) (proposing a WTO jurisprudence built around a "Trade Stakeholder" model). 
accordance with the objective of sustainable development, seeking both to protect and preserve the environment and to enhance the means for doing so...." One could hardly ask for a clearer statement that international trade policy must integrate environmental protection and sustainability of development. Shrimp-Turtle takes cognizance of this preamble language and other contemporaneous expressions of member policy on the trade-environment relationship, and gives it some decorative influence (though it deserves more tangible weight) in construing the GATT 1994. Other WTO agreements with particular relevance for environmental policy, including the agreements on product standards ${ }^{301}$ and on subsidies, ${ }^{302}$ make specific reference to the environment, and reflect as well some underlying environmental policy principles such as the polluter pays principle ${ }^{303}$ and the precautionary principle. ${ }^{304}$ Even without the word "environment" in the GATT text, the WTO system already gives considerable attention to environmental issues and has sufficient authority to address the trade-environment interface.

With respect to the GATT itself, Article XX remains the key. From the beginning, it has made special provision for national policies addressing two core aspects of most environmental policy - the protection of human, animal, or plant life or health under paragraph (b), and the conservation of natural resources under paragraph (g). For the present discussion, we will put aside the question whether the word "necessary" in paragraph (b) unduly constrains health-related environmental measures. Keeping our attention on the conservation of resources question under Article $\mathrm{XX}(\mathrm{g})$, Shrimp-Turtle and Reformulated Gasoline removed almost all interpretive doubts about the broad scope of environmental meas-

301 See Agreement on Technical Barriers to Trade, Final Act, supra note 4, Annex 1A, art. 2.2 (listing "protection of . . . the environment" as one of the "legitimate objectives" for a technical product standard).

302 See Agreement on Subsidies and Countervailing Measures, supra note 4, Annex 1A, art. 8.2(c).

303 See id. art. 8.2(c) (permitting only narrowly-defined partial subsidies to assist firms to meet new environmental standards).

304 See SPS Agreement, supra note 128. The SPS Agreement generally requires measures to be based on an assessment of risk in article 5.1, but allows provisional adoption of protective measures even where "relevant scientific evidence is insufficient in Article 5.7." Id. See also Beef Hormones, supra note 131, paras. 123 24. 
ures that fall within its protective ambit.205 If "clean air" and "sea turtles" are both "exhaustible natural resources," then broad domains of trade-relevant environmental policy should come within Article $X \chi$ protection if the national law or policy is fairly applied. 306

In light of the Appellate Body's generous reading of paragraph $(\mathrm{g})$, the chapeau has become the nub of the Article $X \chi$ interpretation issue. The chapeau, or something like it, is an important component of a "balanced" approach to trade and environment interactions. If Article $X X$ did not impose some constraints on the free exercise of national power to conserve resources, there would be no effective way to rein in national abuse of the exceptions, be they intentional discriminations for economic protectionism or political purposes or de facto discriminations in which facially nondiscriminatory environmental policies cause serious collateral unfairness in trade. It should also be recognized that the chapeau language was not fundamentally new language when it was drafted in 1947; verbal formulas nearly identical to it appear in a variety of treaties or agreements.307 Indeed, the chapeau is not much different from language controlling exercises of delegated authority in domestic legal systems. The United States Administrative Procedure Act, for example, guards against "arbitrary [or] capricious" decisions by executive agencies.?20

Section 4.3. of this Article took serious issue with the Appellate Body's "balancing test" because it sets up the Article $X X$ chapeau in opposition to core trade principles, forcing a rather stark trade-

305 The complainants in Shrimp-Turtle, indeed, claim that they lost the war, even if they won the battle, because of the Appellate Body's generous reading of Article XX(g). Interviews, supra note 17.

305 Indeed, the issues that may remain outside the scope of $(\mathrm{g})$ are ones that do not really relate to the "environment" as such, even if they are traditionally considered issues in "environmental law." Most of these issues are primarily health oriented, such as the manufacture and use of toxic chemicals, or are matters of food safety that are now covered under the more nuanced regime of the separate SPS Agreement.

307 SPS Agreement, supra note 128. Treaty of the European Union, supra note 252 Another trade agreement with language very similar to the SPS Agreement is the North American Free Trade Agreement, art. 712.4 (stating that the Agreement does not "arbitrarily or unjustifiably discriminate").

3085 U.S.C. $\$ 706(2)$ (1994) (instructing courts to hold unlawful and set aside agency actions, findings, and conclusions found to be "(A) arbitrary, capricious, an abuse of discretion, or otherwise not in accordance with law ...."). 
off between trade interests and environmental objectives. The better approach, followed in much United States and European domestic jurisprudence, strives for a dynamic mutual accommodation of interests. The benefits of trade need to be protected from subversion by parochial protectionist interests. At the same time, the vital objectives of environmental protection measures that impinge on economic activity need to be protected from constitutional attack by rent-seeking economic actors and their public sector allies.

To infuse this spirit of mutual accommodation into the multilateral trading system will require a shift away from the current presumption against the trade-legitimacy of any PPM measure toward a presumption that PPM measures within the categories marked out by Article $X X(b)$ and $(g)$ are legitimate exercises of national rights unless complaining Members can demonstrate obviously discriminatory treatment of traded goods or a clear effort to disguise trade restrictions behind a green mask.309 WTO determinations that environmental trade measures are abusively discriminatory should not be lightly made. The complaining Members should be required to put forward at least a prima facie case that each element of the chapeau conditions has been breached: there is trade discrimination; the relevant conditions in the nations are the same; and the discrimination cannot be justified or is arbitrary. As in national legal systems, even if some discrimination in application of the measure can be established there should be a presumption of legitimacy for the national environmental measure and a deference to the responding nation's explanation or justification for the observed discrimination.

Such a strict reading of the chapeau conditions would open up a much broader policy space for environmental trade measures, both multilateral and unilateral. Apprehensive trade policy makers will undoubtedly argue that establishing such a wide exception to the GATT disciplines would undermine the multilateral trading system and put it on a "slippery slope" toward 1930s-style eco-

309 For an interesting argument that the PPM concept has no textual or principled basis in the GATT, see Robert Howse \& Donald Regan, The Product/Process Distinction - An Illusory Basis for Disciplining "Unilateralism" in Trade Policy, 11 EUR. J. INT'L L. 249 (2000). Jackson, however, looks askance at key parts of Howse's argument. John H. Jackson, Comments on Shrimp-Turtle and the Product Process Distinction, 11 EUR. J.INT'L L. 303 (2000). 
nomic warfare. I reject such arguments as the fantasies of the fearful. The protection against arbitrary or unjustifiable discrimination, even when relaxed, will still serve as a strong check on abusive trade restrictions. Among the major trade-environment cases that have gone through trade dispute settlement in the past few years, only one-Tuna-Dolphin-would come out differently under the more rigorous but more forgiving reading of the chapeau I am proposing. The discrimination against foreign-refined gasoline in Reformulated Gasoline was, by the implicit admission of the United States Environmental Protection Agency, unjustifiable, and the move by the United States Congress to block EPA from correcting the discrimination gave strong evidence of an effort to maintain a disguised restriction on trade. In Shrimp-Turtle, as this Article has acknowledged, there were patterns of arbitrary discrimination in the flawed implementation of Section 609 that did need to be corrected, and were corrected by revisions to the Section 609 guidelines and enhanced diplomatic efforts.

Moreover, I do not believe that governments would view a more limited construction of the chapeau conditions as an invitation to create new environmental trade restrictions, except in isolated instances. There are many restraints on the adoption of an environmental trade measure. First, governments understand that such measures can be two-edged swords. In the SPS negotiations, they carefully balanced the need to have a clear right to take SPS measures against the risk that others would apply similar SPS measures against their own exports. Second, trade restrictions tend to have domestic economic costs that chill overeager advocates of trade restrictions. Finally, there are not that many environmental issues for which there are significant environmental effects from the activities of trading partners that cause concern to a country taking the measure, and even fewer that meet the specific conditions of paragraphs (b) and (g). In particular, the fact that Article $X X(\mathrm{~g})$ allows trade measures only in conjunction with restrictions on domestic production or consumption of like products will sharply narrow, if not close off completely, some of the worst nightmare scenarios of traders. For example, the domestic production-cum-restriction condition would make it difficult for North Americans to impose Article $X X$ measures on tropical timber (no production) or on countries not taking agreed emission reduc- 
tions to reduce their global-warming impact (no or weak domestic restrictions).

A more rigorous, modulated interpretation of the Article $X X$ chapeau will also fit better in the larger context of international policy addressing diverse and complex environmental problems. The Appellate Body, and the international community in general, insist that multilateral initiatives are to be preferred to unilateral ones. That is a fine principle, though not part of the legal regime of the GATT.310 But treaty regimes, especially multilateral ones, are notoriously difficult to establish. In this context as well, it is important to consider the policy options available to governments that want to promote, or give effect to, environmental protection or resource conservation measures of international scope in the absence of treaty. More particularly, in the context of GATT Article $X X$, if a country has adopted a natural resource conservation program at the national level, and wants to protect that program from erosion or disruption by persons beyond its national jurisdiction, what legal instruments might it legitimately use? With rare exceptions, a command-and-control response is not acceptable-there is absolutely no basis in international law for one nation to impose an internationally enforceable obligation on nationals of another, or on another nation directly, to observe a particular form of behavior. Voluntary programs are clearly permissible. Purely voluntary programs may be effective in a few cases, but are likely to be inadequate in most situations to modify the behaviors that are giving rise to the environmental harm. Thus, voluntary programs of consultation, information sharing, and even technical assistance will usually need to be supplemented with meaningful economic incentives to give sufficient impetus to other governments to shift their policies in the desired direction.

One obvious economic incentive that works internationally is for the nation promoting the environmental protection measure to bestow new trade benefits on or to withdraw existing ones from the target countries. For reasons of political economy that apply in all dimensions of trade policy, the carrot of granting positive trade benefits, however attractive in theory, is rarely used in practice. The stick of withdrawing trade benefits is the more common incentive mechanism. Between WTO members, of course, that in-

310 See supra Section 4.2.3. 
centive can only be legitimately applied within the rules of the WTO agreements. GATT Article XX $(\mathrm{g})$ is the provision specifically relevant in this context. Looking at (g) alone for the moment, it clearly supposes that the government of one nation may have in place a resource conservation regime which, to be effective, would need to be shielded from contradictory actions by the nationals of other nations. It thus allows an exception from GATT obligations for trade measures, such as restrictions or conditions on exports or imports, that relate to and are "conjoined" with the domestic regime. Those trade restrictions could be written in such a way that they could be lifted if the circumstances in the affected countries change. Indeed, from a trade liberalization and trade harmonization point of view, it would be desirable for the restriction to be written in this way, so that the affected countries can elect to respond to the economic incentive by making the appropriate policy adjustments in order to avoid economic injury. Thus, in support of the multilateral trading system, Article $X X(\mathrm{~g})$ should be read to allow such economic incentives to operate, not to foreclose them. The only further stipulation should be, and is, the chapeau's injunction that such an adjustment of trade relations in support of the resource conservation regime should be applied in a defined and predictable way-not arbitrarily-and in an even-handed manner such that any variation in treatment from one country to the next is justifiable within the context of the program in question.

\subsection{How the WTO Can Implement a Reinterpretation of Article XX}

Procedurally and institutionally, there are at least three basic approaches to Article $X X$ reinterpretation within the existing framework. First, the Appellate Body could revise its Article $X X$ chapeau analysis in the next suitable dispute. Second, the WTO Council, or the Conference of Ministers, could adopt an interpretive statement that would supplant Shrimp-Turtle as the definitive WTO understanding of the meaning of Article XX. Finally, Article $X X$ could be amended to provide a new textual foundation for the necessary balancing test. If one begins to think outside the "box" of the existing institutional systems, other approaches can be imagined. I will give brief consideration to one that has already been proposed and discussed-a pattern of respect for, if not deference to, an international environmental body or other non-WTO entity that would make its own assessment of whether a trade- 
based environmental measure satisfied the Article $X X$ chapeau conditions.

Reconstructing Article $X X$ through a future Appellate Body report is problematic for several reasons. To begin with, it is a less stable or secure approach than the others. If the Appellate Body can shift its interpretation in significant ways from its Shrimp-Turtle approach to some new approach-an available option in principle-there is no assurance that it will not shift back to ShrimpTurtle or on to some third interpretation in subsequent cases.311 This strategy is also unpredictable in timing and in the particular rule that might emerge, given that it would depend on when the next Article XX case appeared (which is completely beyond WTO control) and the particular fact pattern of that case (given that most observers agree that a balancing test must remain rather vague and be applied in each case with sensitivity to the balance of factors in the matter before the adjudicator). The different styles of Appellate Body analysis of the Article XX chapeau between Reformulated Gasoline and Shrimp-Turtle illustrate this fact-specific effect, as does the trade-environment jurisprudence of the European Court of Justice and the United States Supreme Court under similar balancing tests. ${ }^{312}$

There are other widely-recognized problems with the trade dispute settlement process for trade-environment policy making. First, the WTO disavows any competence on environmental policy. In their 1994 Decision on Trade and Environment, the world's trade ministers officially reiterated the common observation that the "competence of the multilateral trading system ... is limited to trade policies and those trade-related aspects of environmental policies which may result in significant trade effects for its members." ${ }^{313}$ It is impossible to develop an integrated and mutually supportive trade-environment policy by considering only the trade dimension. As a senior U.S. official remarked, when trade and en-

311 There is, however, an evolving tradition within the WTO dispute settlement system to "take into account" the "legitimate expectations" that panel and Appellate Body reports create. AB Recourse Report, supra note 23, paras. 108-109.

312 Daniel Esty \& Damien Geradin, Market Access, Competitiveness, and Harmonization: Environmental Protection in Regional Trade Agreements, 21 HARV. ENVT'L L. REV. 265 (1997).

313 GATT Secretariat, $A$ Decision on Trade and Environment, MTN.TNC/MIN (94)/1/Rev. 1 (Apr. 14, 1994). 
vironment issues are taken up at the GATT [WTO], "environmental policymakers must be at the table." 314 But there is little room for environmental policy makers at the table of dispute settlement panels and no room at all in the Appellate Body. ${ }^{315}$

The dispute settlement process also has wealonesses in terms of transparency and participation. In "Procedural Guidelines" on trade and environment addressed to its member governments, the OECD emphasized the need to develop "appropriate means to achieve transparency."316 Although the WTO Dispute Settlement Understanding subsequently made some strides toward a greater level of openness, the process still falls significantly short in terms of integrating environmental considerations into the resolution of disputes. ${ }^{317}$ The United States, in particular, has pressed for greater openness and rights of participation in the WTO process.318 In Shrimp-Turtle, the Appellate Body, to its credit, responded to the shifting mood by opening the door to consideration by dispute settlement panels of written briefs prepared by nongovernmental organizations if those are included in a member's submission. 319

314 Robert Sussman, Deputy Administrator of the United States Environmental Protection Agency, remarks at a high-level meeting at the Organization for Economic Cooperation and Development (OECD) (Dec. 1993) (transcript on file with the author).

315 It is possible for a person whose basic background is in environmental affairs to be appointed to a WTO dispute settlement panel, and one such person was on the panel in the Shrimp-Turtle case. The Appellate Body, however, is a fixed group of persons selected, appropriately, for their expertise in trade policy.

316 Report on Trade and Environment, para. 17, OECD doc. OCDE/GD(93)49 (June 1993).

317 As the OECD's 1995 Report on Trade and Environment to the OECD Council at Ministerial Level diplomatically states: "Some concerns have been expressed with both trade and environmental dispute settlement mechanisms." OCDE/GD(95)63, at 11 .

318 Some U.S. proposals were set forth in a document circulated before a meeting of the WTO General Council. E.g., General Council Informal Consultations on External Transparency, Submission from the United States, WTO General Council, WT/GC/W/413 (Oct. 10, 2000).

319 AB Report, supra note 9, para. 89 ("We consider that the attaching of a brief or other material to the submission of either appellant or appellee, no matter how or where such material may have originated, renders that material at least prima facie an integral part of that participant's submission."). The Appellate Body reiterated this position in the recourse proceeding, accepting an amiazs brief appended to the U.S. submissions but declining to give it much weight because the United States did not endorse it, and declining to take into account at all another amicus brief submitted directly to it. AB Recourse Report, supra note 23, paras. 75- 
The doors to the oral hearings in the dispute settlement proceeding, however, remain tightly shut.

Another reason not to leave the issue of Article $X X$ interpretation to the dispute settlement process is that the mandate of the panels and the Appellate Body, like that of adjudicators in most legal systems, is restricted to the interpretation and application of existing law. Once a dispute has gone beyond the initial consultation between the parties, creativity or compromise in finding solutions outside the established framework is foreclosed. As the GATT panel put it in the Tuna-Dolphin report,

if the Contracting Parties were to permit import restrictions in response to differences in environmental policies ... they would need to impose limits ... and to develop criteria so as to prevent abuse .... [I]t would therefore be preferable for them to do so not by interpreting Article $X X$, but by amending or supplementing the provisions of the General Agreement or waiving obligations thereunder. ${ }^{320}$

A final reason not to rely on the Appellate Body for a reinterpretation of Article $X X$ has to do with rules of interpretation and institutional legitimacy. This article has argued strongly that the Shrimp-Turtle analysis has on several points lacked a textual foundation in Article XX. As the leading body within the WTO charged with legal interpretation of the WTO agreements, the Appellate Body can, and should, strive for an interpretation rooted in the plain meaning of the texts. But as Professor Jackson has pointed out, it may no longer be appropriate to hark back to "original intent" in construing Article $X X .{ }^{321}$ There is now a fiftyyear history of its interpretation by GATT panels, by the Appellate Body itself, and by decisions and statements of the member governments through WTO committees and council documents. The

78. The obvious limitation in this limited right for non-governmental organizations to present their views in a WTO dispute is that it depends entirely on the willingness of one of the participating governments to include those views in its own submissions in the dispute settlement process.

320 GATT Dispute Panel Report, U.S. - Restrictions on Imports of Tuna, 30 I.L.M. 1598, 1623 para. 6.3 (Aug. 16, 1991) (circulated but not adopted).

321 Jackson, supra note 286, at 304 (discussing bright lines with changes in flexibility). 
Appellate Body may not turn a blind eye to the living, organic interpretation of Article $X X$ that has thus emerged, and which it itself had some role in creating. Shrimp-Turtle itself has the effect of embedding the prevailing understanding of Article $X X$ deeper in the system. Therefore, to the extent that the Shrimp-Turtle interpretation conforms to established or preferred interpretations of Article XX by virtually all WTO Members, it is not the Appellate Body's role to chart a new interpretation even if it squared better with the GATT text than the current one.322 In Shrimp-Turtle, the Appellate Body refers repeatedly to its task to discern the expectations or intentions of the WTO Members in interpreting the agreement. ${ }^{323}$ Though the line between textual interpretation and policy making is not always clear, the proposed reinterpretation of Article $\chi \chi$ arguably departs significantly from the past and has multiple ramifications for the future, and so should be considered as an exercise in making policy. As such, the responsibility for it lies with the policy-making bodies of the WTO-the Council, and ultimately, the Ministers - not with the adjudicatory Appellate Body.

Skipping ahead to the third possible approach -a textual change to Article $X X$ itself by formal amendment-this strategy is fraught with difficulties that have been raised in the Committee on Trade and Environment deliberations on the relationship between the WTO agreements and multilateral environmental agreements.324 The greatest problem here is the formal one of securing ratification of a textual amendment by the appropriate national bodies in each of the Member states. Without belaboring this point, suffice it to say that textual amendment should be viewed as a last resort, a strategy to be employed only when the sought-after change is so significant or raises matters of such fundamental principle that each Member should be afforded the opportunity to determine for itself whether or not to accept the change to its legal obligations. The entire premise of this Article is that a fresh inter-

322 Vienna Convention, supra note 264 , art. 31, para. 3. The Vienna Convention instructs treaty interpreters to take into account subsequent agreement of parties on interpretation or subsequent practice in the application of the treaty.

323 See AB Report, supra note 9, para. 114 (referring to the words of the agreement "must be" as the first source for understanding "the object and purpose of the states party to the treaty").

324 WTO Ministerial Declaration, WTO Ministerial Conference, 4th Sess. (Doha), WT/MIN(01)/DEC/W/1 para. 6 (Nov. 9-14, 2001) ("We strongly reaffirm our commitment to the objective of sustainable development...."). 
pretation of Article $X X$ would not represent a basic redefinition of rights and obligations, but would simply rectify a bias that has arisen in striking the balance between rights and obligations that are, in principle and when viewed individually, widely-accepted and textually recognized.

Thus, the best among the three available institutional procedures for re-interpretation of Article $X X$ is for the Council or the Conference of Ministers to adopt an interpretive statement. This is the proper forum for an exercise of policy making authority by the WTO members. It also has the advantage of providing the best opportunity for a forwarding-looking and nuanced interpretation that can have enduring value and provide rather specific guidance about how to maintain a suitable balance between trade and environment in cases where it proves impossible to fully satisfy both objectives simultaneously. It is the same strategy proposed by several governments for formulating any special guidance on trade policy accommodation of trade-based measures under multilateral environmental agreements.

Another reason to follow the strategy of a Council interpretive statement is that it puts the question of Article XX interpretation into a political negotiating context. Not only is this the right context for an adjustment of Member expectations with regard to Article $X X$, it also opens the possibility of linking an Article $X X$ reinterpretation to other issues that may be on the negotiating agenda of the membership.

Having proposed a Council interpretation, the difficulties as well as the possibilities become apparent. The united opposition of developing countries to labor and environment initiatives by the United States contributed to the collapse of the Seattle Conference of Ministers in December 1999. A similar clash of views occurred at the Doha, Qatar ministerial in November 2001. The ministerial declaration gives rather prominent attention to environmental issues, but in the end the ministers only commit to further discussions and a special effort to resolve the discrete issue of the relationship of the GATT to multilateral environmental agreements. Such vagueness and foot-dragging does not bode well for a nearterm resolution of the Article XX problem. Political difficulties alone, though, are not reason to abandon the cause altogether. 


\section{CONCLUSION}

The WTO has critical work to do in support of environmental protection. Dismantling agricultural protectionism and controlling subsidies to fishing industries, for example, are key and urgentlyneeded extensions of liberal international trade policy to promote sustainable development. The Doha meeting of the world's trade ministers has finally put these issues squarely on the agenda for negotiation, giving some cause for cautious optimism that these matters may be addressed by explicit WTO rules in due time.323 But Shrimp-Turtle revives substantial doubts about the WTO's legitimacy as a leading forum for defining the necessary patterns of "mutual support" 326 between liberalized international trade and sustainable development. The outpouring of civil society's antipathy to the WTO in Seattle in December 1999, and the ineffectual response of the world's governments to the revealed public mood, show just how much a sense of trade policy illegitimacy threatens further work toward open, nondistorting patterns of international exchange.327 To maintain and reinvigorate the multilateral trade system, new modes of thinking within the WTO are urgently needed. As one step in that direction, the WTO must restore Article $X X$, which is an original and integral element in the trade policy structure, to its rightful role as a safe harbor for unilateral government actions in pursuit of vital national and international interests including the protection of the environment.

The biologist E.O. Wilson has expressed the powerful judgment that the extinction of species is "the folly for which our descendants are least likely to forgive us." ${ }^{328}$ In this sense, it was folly for the Appellate Body to interpret Article $X X$ to preclude the application of trade leverage by a country in pursuit of an urgent

325 Id. paras. 13-14 (reconfirming commitment to "correct and prevent restrictions and distortions in world agriculture markets").

326 The idea that trade and environment policies should be "mutually supportive" is expressed in the Rio Declaration and Agenda 21. See supra text accompanying note 132

327 For example, a carefully crafted consensus proposal to begin to bring fisheries subsidies under control was one constructive initiative abandoned in the collapse of the Seattle ministerial meeting. Trade and Environment Apris Seallle, Bridges between Trade and Sustainable Development, vol. 4, no. 1, Jan.-Feb. 2000, at 3, aoailable at http://www.ictsd.org/English/BRIDGES4-1.pdf.

328 Edward O. Wilson, Biophilia and the Consercation Ethic, in THE BlopHmIA HYPOTHESIS 119, 121 (Stephen R. Kellert \& Edward O. Wilson eds., 1993). 
correction to fishing practices that threaten to extinguish several species. When an overzealous shielding of economic interests takes precedence over the prevention of an irreversible loss to our biodiversity heritage, something is "rotten" in the state of the WTO. Let us hope that governments and civil society can find rational ways to correct the rotten state of affairs rather than killing the WTO, which would be suicidal for the environmental community as much as for the trade community. 